Portland State University

PDXScholar

8-13-1976

\title{
Thermal Ecology and Movement in the Leopard Lizard, Gambelia Wislizeni, Baird and Girard
}

Marvin Lynn Abts

Portland State University

Follow this and additional works at: https://pdxscholar.library.pdx.edu/open_access_etds

Part of the Biology Commons

Let us know how access to this document benefits you.

\section{Recommended Citation}

Abts, Marvin Lynn, "Thermal Ecology and Movement in the Leopard Lizard, Gambelia Wislizeni, Baird and Girard" (1976). Dissertations and Theses. Paper 2404.

https://doi.org/10.15760/etd.2401

This Thesis is brought to you for free and open access. It has been accepted for inclusion in Dissertations and Theses by an authorized administrator of PDXScholar. For more information, please contact pdxscholar@pdx.edu. 
AN ABSTRACT OF THE THESIS OF Marvin L. Abts for the Master of Science in Biology presented 13 August 1976.

Title: Thermal Ecology and Movement in the Leopard Lizard, Gambelia wislizeni Baird and Girard

APPROVED BY MEMBERS OF THE THESIS COMMITTEE:
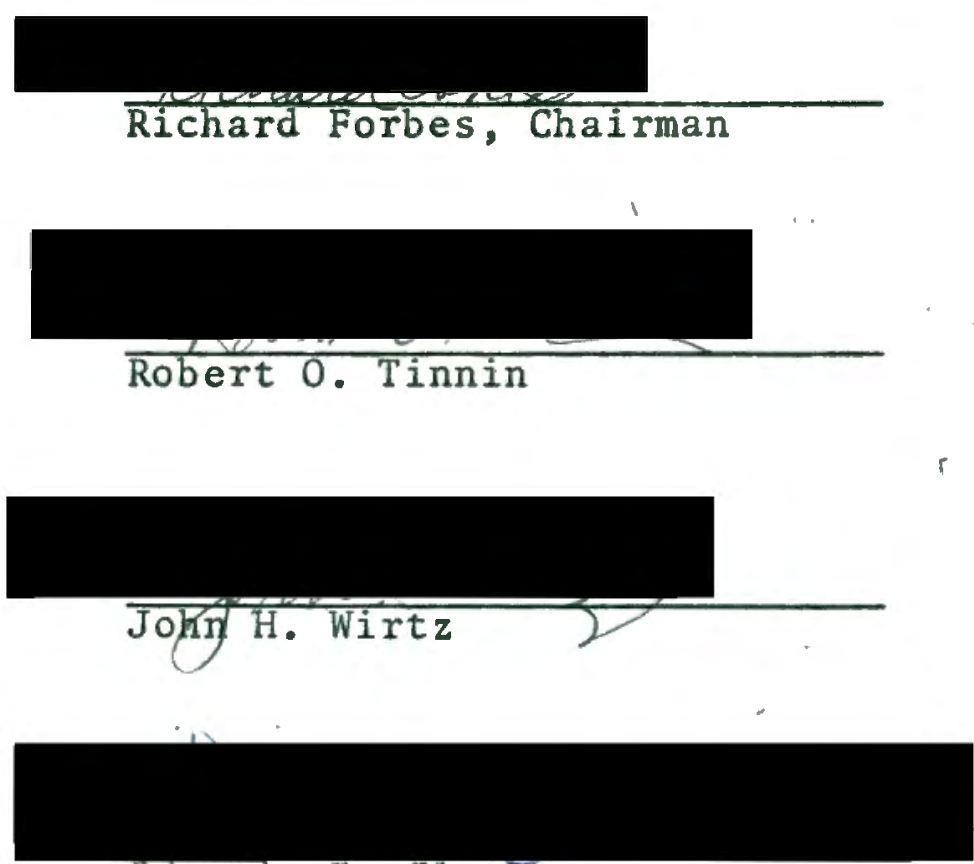

Quentin D. Clarkson

Thermal ecology and movement of the Leopard Lizard, G. wislizeni were studied at Frog Spring, adjacent to the Alvord Desert, and at various locations throughout the Alvord Basin.

Seasonal activity is known to occur from early May to mid-October, but abundance gradually decreases after late July. During favorable late spring, and summer 
weather lizards exhibit a bimodal pattern of diel activity with some activity occurring at all hours of the day between 0600 and $1800 \mathrm{H}$. At other times activity was unimodal. Emergence was apparently largely temperature dependent and did not occur until sand temperature approximated $21^{\circ} \mathrm{C}$. Retreat appeared to be temperature independent, and was initiated by exogenous or endogenous stimuli at sand temperatures often above body temperatures acceptable for normal activity. For the period of study, juveniles exhibited diel activity patterns similar to adults, and were found during all hours in which adults were'encountered.

Body temperatures of field active lizards, largely affected by the immediate weather conditions, ranged from $18.6^{\circ}$ to $43.4^{\circ} \mathrm{C}$. Because of a variety of thermoregulatory response (changes in location, posture, and orientation, color change, burrowing, shade-seeking, and panting), even during unfavorable weather conditions, most body temperatures fell within a narrower range. Nonetheless, the ability of field active lizards to precisely thermoregulate was limited, and the levels of body temperature maintained usually encompassed a broader range than those maintained in a thermal gradient. The mean body temperature of field active lizards during favorable weather conditions, and that of active lizards in a thermal gradient, did not differ significantly, and seemed to indicate a narrow range of 
body temperature preference. However, prevailing weather conditions were frequently unfavorable, thus limiting the extent of time during which selection of preferred body temperature could occur. Consequently, though activity depended on the attainment of certain temperature levels, G. wislizeni was forced to adapt to a broader range of body temperatures when performing most routine tasks. The necessity of precision thermoregulation is unclear, but apparently physiological efficiency was not greatly diminished over the broad range of body temperatures field active lizards were often accepting.

Relatively speaking, movement in G. wislizeni was extensive. Adult males occupied an average area more than twice the size of adult females and juveniles. Plotted polygons, constructed from sighting points, tended to be elongate. The extent to which lizards occupied a definite home range was uncertain. Adult males, continuously expanding the area occupied, probably lacked a home range. Adult females, demonstrating. 1ittle area expansion, perhaps maintained a home range. Territoriality by means of intraspecific display or aggression appeared negligible in G. wislizeni. Adult males did not demonstrate such behavior toward one another. Based on a limited extent of area overlap, adult females may have exhibited territoriality toward members of their sex. Movement per hour revealed results similar to area occupied, with adult males travel- 
ing an average distance of nearly three times as great. as adult females and juveniles. Greatest distances frequently coincided with peak diel activity. Individual moves were frequent in adult males and juveniles, but infrequent in adult females. Adult female long moves were similar in distance to adult males, but exogenous stimuli perhaps linked with home range maintenance restricted the frequency of such jaunts. Movement in G. wislizeni appeared independent of environmental thermal conditions when body temperature was within the range acceptable for normal activity. Diel movement appeared to be random in the species. Seasonal movement in juveniles, based on dispersion data, appeared directional. 
THERMAL ECOLOGY AND MOVEMENT IN THE LEOPARD

LIZARD, Gambelia wislizeni BAIRD AND GIRARD

\author{
by \\ Marvin L. Abts
}

A thesis submitted in partial fulfillment of the requirements for the degree of

MASTER OF SCIENCE

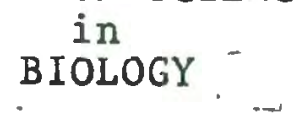


TO THE OFFICE OF GRADUATE STUDIES AND RESEARCH:

The members of the Committee approve the thesis of Marvin L. Abts presented 13 August 1976.
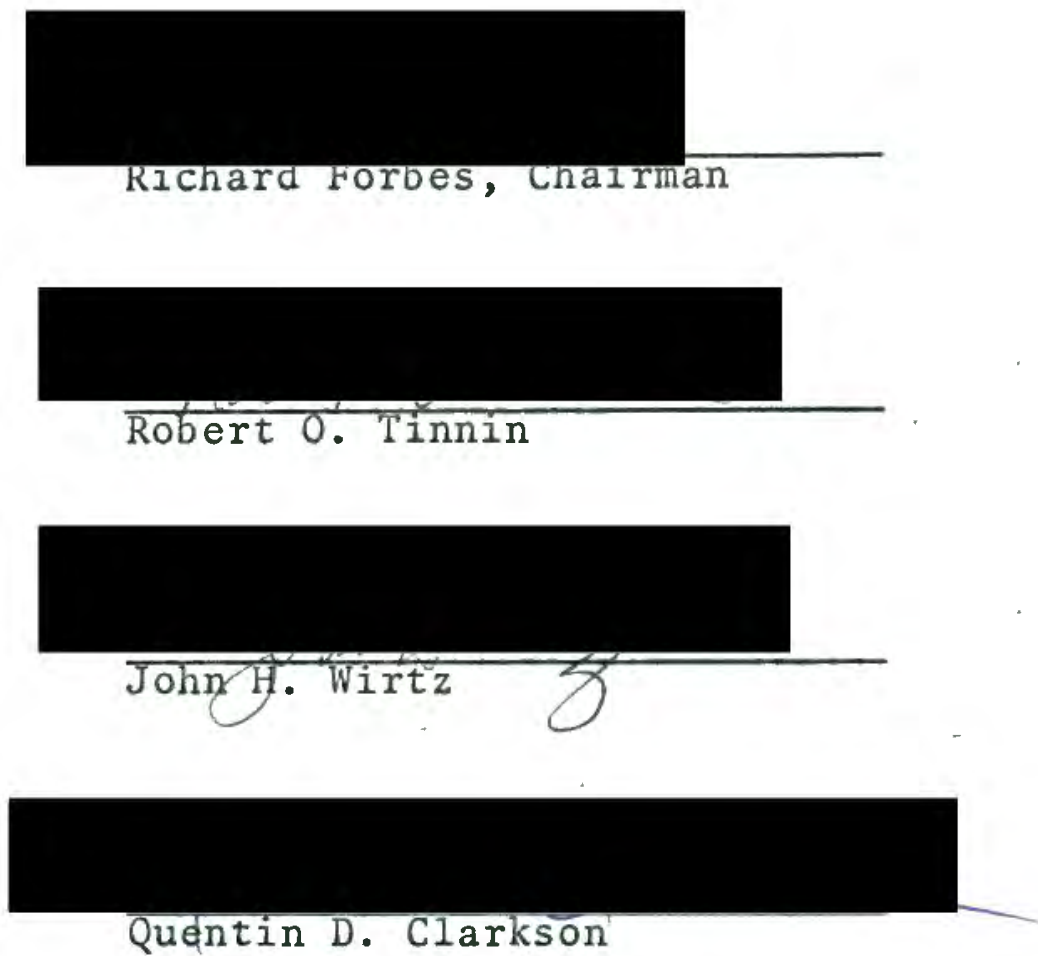

APPROVED:

W. Herman Taylor, Chairman, Department of Biology

Stanley E. Rauch, Dean, Graduate Studies and Research 


\section{ACKNOWLEDGEMENTS}

I greatly appreciate the tremendous effort made by my field assistants: Greg Evans, Susan Linstedt, and Mark Smith. I thank Calvin Abts, John and Becky Palmer, Mike Ruether, Frank Sheets, and Guy Skippers for additional help in the field. I thank Ellen Benedict and Susan Foster for making plant identifications. I thank Wesley Abts for providing tools and constructing the thermal gradient chamber. I thank Dr. Quentin Clarkson and Peter Paquet for invaluable statistical assistance. I thank Fred Nussbaum and Dairy Shell for doing the computer programming. I am indebted to Drs. Richard Forbes, Robert Tinnin, and John Wirtz for constructive criticism of the original draft. I thank Mary Dozark for doing the typing and her husband, Dean, for assistance in preparing the figures. I thank my wife, Ginger, for many technical services. Her patience, understanding, and encouragement was highly inspirational, and contributed a, great deal to the success of the study. 
ACKNOWLEDGEMENTS. . ........................ ii

LIST OF TABLES......................... vi

LIST Ol: figuRLS........................ vii

INTRODUCTION............................. 1

Study Area......................... 5

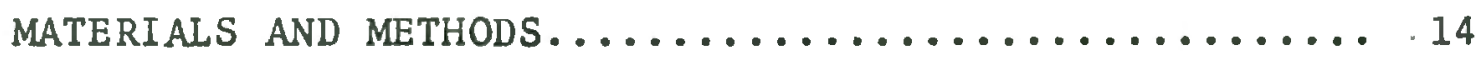

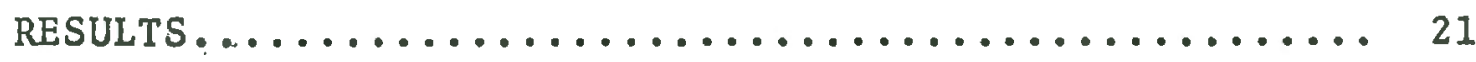

Seasonal Periodicity...................... 21

Diel Activity....................... 23

Effect of Environmental Temperatures on Body

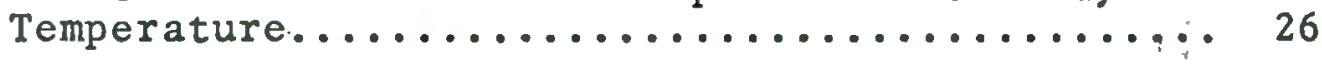

Relation of Time of Day to Body Temperature.... 50

Methods of Thermoregulation.............. 53

Heat stress........................ 65

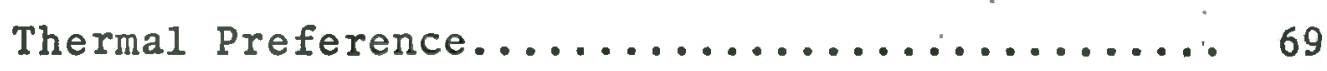

Home Range Size and Territoriality.......... 73

Kinds of Movements................. 87

Distance Traveled per Hour............... 90

Relation of Environmental Temperatures to

Distance Traveled per Hour................ 91

Relation of $\mathrm{T}_{\mathrm{B}}$ to Distance Traveled per Hour.... 93

Relation of Size and Body Proportions to

Distance Traveled per Hour................ 94

Relation of Sex to Distance Traveled per Hour... 95

Relation of Time of Day to Distance Traveled

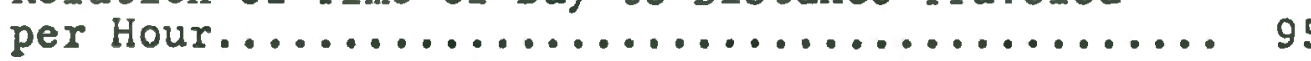


PAGE

Mean Direction and Circular Variance.......... 96

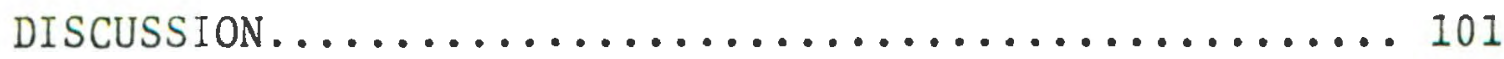

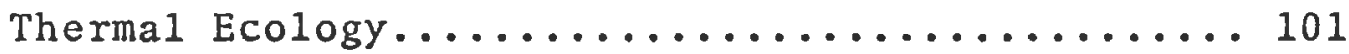
LITERATURE CITED........................... 124 


\section{LIST OF TABLES}

TABLE

PAGE

I Vertebrates Sighted in Vicinity of Frog Spring............................. 13

II Meteorological Data Covering Seasonal Periodicity....................... 15

III Multiple Regression - Components Effecting

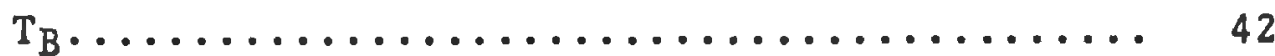

IV Multiple Regression - Thermal Gradient, TEN Effecting $T_{B} \ldots \ldots \ldots \ldots \ldots \ldots \ldots \ldots \ldots$. 44

V Multiple Regression...Thermal Gradient, Lag Period.......................... 46

VI Mean Hourly Snout-Vent Lenght and Weight for a Population of Gambelia wislizeni...... 48

VII Mean llourly $T_{B}$ for a Population of

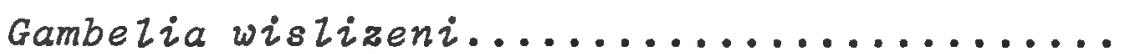

VIII Home Ranges $\left(\mathrm{m}^{2}\right)$ Computed on the Basis of 3 or More Sightings. Numbers in Parentheses

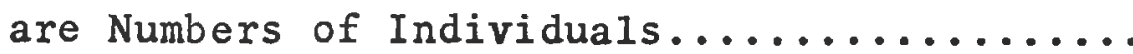




\section{LIST OF FIGURES}

FIGURE

PAGE

1 Distribution of Gambelia wislizeni........... 2

2 The Distribution of Gambelia wis zizeni in

Harney County, as indicated by the shading.... 7

3 Alvord Desert Region.................... 8

4 Pueblo Valley.......................... 9

5 Catlow Valley.......................... 10

6 Diel Activity of Gambelia wislizeni.......... 24

7 Daily Course of Mean Difference in Temperature (TD) Between Gambelia wislizeni and Selected Environmental Readings................. 27

8 Comparison of Gambelia wislizeni Body Temperatures and Environmental Temperatures......... 28

9 Relationship of Body Temperature ( $\left.\mathrm{T}_{\mathrm{B}}\right)$ of Gambelia wislizeni to Shaded Air Temperature $\left(\mathrm{T}_{\mathrm{ASH}}\right) \ldots \ldots \ldots \ldots \ldots \ldots \ldots \ldots \ldots \ldots \ldots \ldots \ldots \ldots \ldots \ldots . \ldots \ldots$

10 Relationship of Body Temperature $\left(\mathrm{T}_{\mathrm{B}}\right)$ of Gambelia wistizeni to Sun Soil Temperature

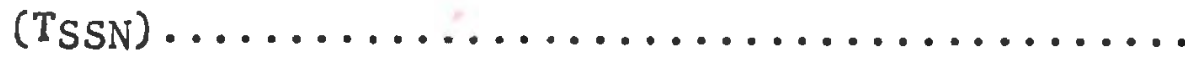

11 Relationship of Body Temperature $\left(\mathrm{T}_{\mathrm{B}}\right)$ of Gambelia wislizeni to Shaded Soil Temperature $\left(\mathrm{T}_{\mathrm{SSH}}\right) \ldots \ldots \ldots \ldots \ldots \ldots \ldots \ldots \ldots \ldots \ldots \ldots \ldots \ldots \ldots \ldots \ldots \ldots$

12 Frequency Distribution of 283 Body Temperatures of Active Gambelia wislizeni 
viii

FIGURE

PAGE

13 Frequency Distribution of 256 Body Tempera-

tures of Gambelia wislizeni Recorded in a

Thermal Gradient Chamber............... 41

14 Relationship of Body Temperature $\left(\mathrm{T}_{\mathrm{B}}\right)$ of

G. wislizeni to Time of Day.............. 54

15 Based on 57 Individual Hourly Observations,

Diel Changes in Location of Gambelia

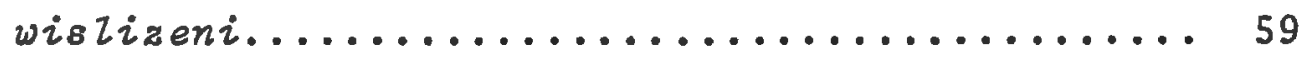

16 Thermoregulatory Posture................61 61

17 Average Home Range Area of Adult Male Gambelia wislizeni at Indicated Number of Sightings.... 76

18 Average Home Range Area of Adult Female (Dots)

and Juvenile (Circles) Gambelia wislizeni at'

Indicated Number of Sightings............ 78

19 Home Ranges of Juverile Male (Solid Lines)

and Female (Broken Lines) Gambelia wislizeni

at Frog Spring.................. 84

20 Home Ranges of Adult Male Gambelia wislizeni at Frog Spring.................... 84

21 Home Ranges of Adult Female Gambelia wislizeni at Frog Spring..................... 85

22 Circular Plotting of Directional Movement in Gambelia wiszizeni at Frog Spring.......... 97

23 Off-Site Activity of Gambelia wistizeni Up To

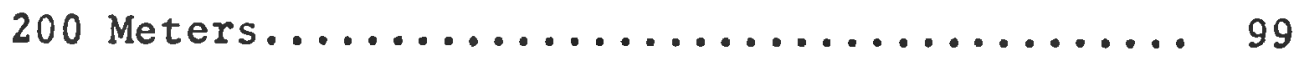


24 Frequency Distribution of 203 Measurements of Snout-Vent Length of Gambelia wislizeni.... 117 


\section{INTRODUCTION}

Leopard lizards (Gambelia wislizeni Baird and Girard) are diurnal lizards of moderate size which occupy much of the arid and semi-arid basin terrain in western North America (Figure 1). They favor brushy flatlands, rolling hills, and alluvial fans up to clovations of about 1800 meters above sea level. They occur on a variety of soil types, but avoid rough rocky areas. The vegetation of these habitats is variable, and may be sparse to dense; the only requirement of the lizards is intermittent open areas in which they can bask and find food. G. wislizeni appear to be most abundant in areas containing numerous rodent burrows which offer a means of escape from predators and adverse weather.

Baird and Girard (1852) placed leopard lizards with collared lizards in the genus Crotaphytus. Baird (1858) casually introduced the name Gambelia, and Smith (1946) advanced the epithet to generic status. Some systematists have accepted Gambelia at either the generic level (Brattstrom, 1953) or subgeneric level (Brattstrom, 1958;

Tanner and Banta, 1963; and Weiner and Smith, 1965). Others (Savage, 1958; Robison, and Tanner, 1962; Banta and Tanner, 1968; and Montanucci, 1969) have retained all species in the genus Crotaphytus. Montanucci et ar. (1975) may have gathered enough differing information between leopard lizards and collared lizards to make it practical 
2

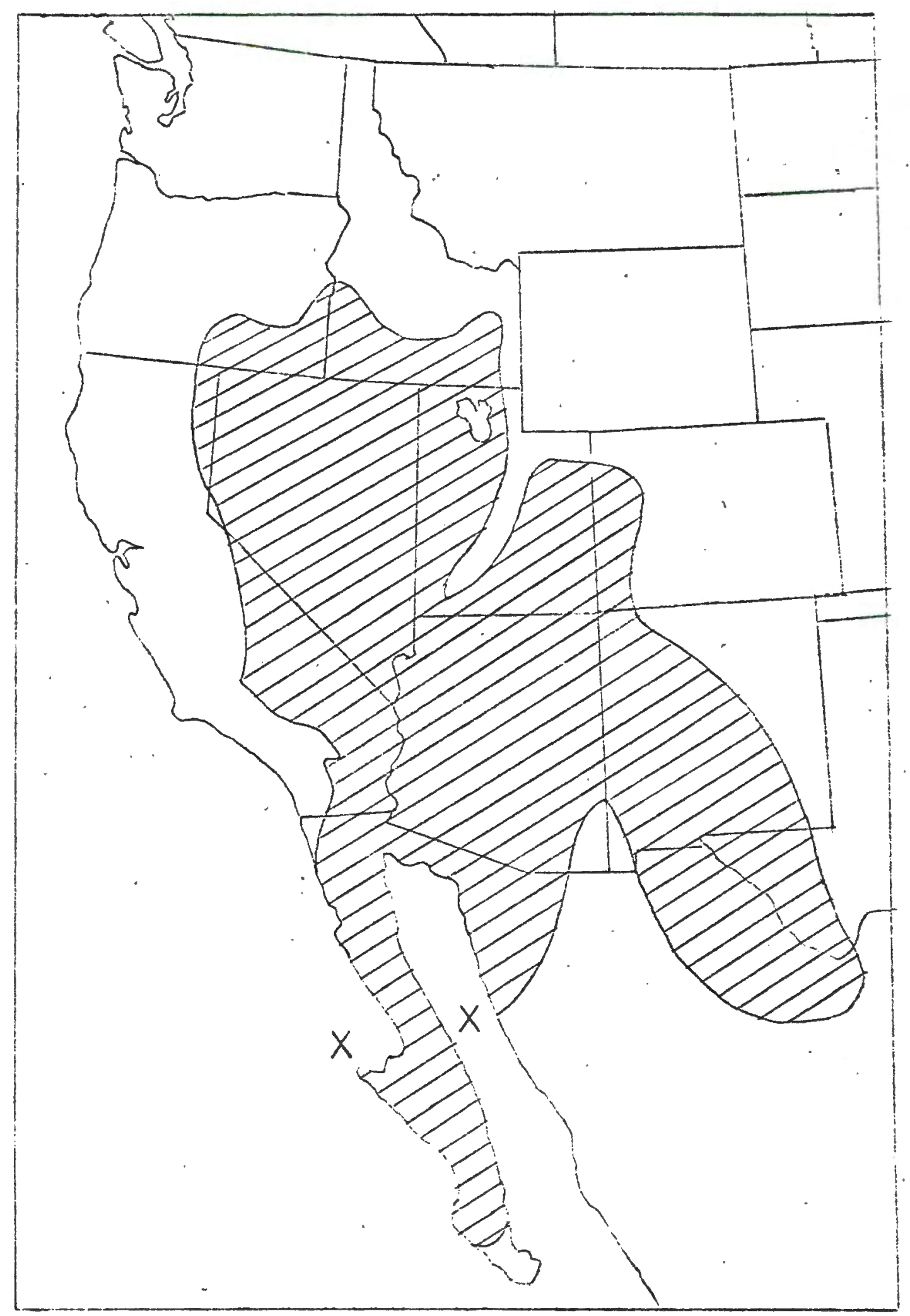

Figure i. Distribution of Gambelia wislizeni. 
to place the former in the genus Gambelia. Baird and Girard (1852) proposed wislizeni for the species epithet. Stejneger (1890) described leopard lizards from the San Joaquin Valley, California and called them Crotaphytus silus. Recently, Montanucci (1965, 1967, 1969, and 1970) has thoroughly investigated the status of $G$. sizus and belives this group should be given species rank separate from G. wislizeni. The present study deals with G. wislizeni. Various aspects of the biology of leopard lizards have been reported from different geographical areas by Taylor (1912), Richardson (1915), Knowlton (1934), Knowlton and Thomas (1936), Linsdale (1938), Atsatt (1939), Fautin (1946), Smith (1946), Stebbins (1954), Tinkle (1959), Miller and Stebbins (1964), Carpenter (1967), Norris (1967), Porter (1967), and Milstead and Tinkle (1969). Observations on reproduction include those of Shaw (1952), Woodbury (1959), Turner (1969), and Fitch (1970). Mean body temperatures were reported by Cowles and Bogert (1944), Brattstrom (1965), Cunningham (1966), Pianka and Pianka (1970), and Parker and Pianka (1976). Ecological studies on leopard lizards have been conducted in California (Montanucci, 1965 and 1967), Colorado (McCoy, 1967), Nevada (Tanner and Krough, 1974a and 1974b), and at various other localities in the western United States and Mexico (Parker and Pianka, 1976). Although Brookings (1934) observed leopard lizards in Oregon, no ecological studies 
have been conducted on Oregon populations. For additional information on the biology of leopard lizards see references in Parker and Pianka (1976).

Knowledge of lizard thermal ecology is fragmentary. The studies of Heatwole (1970) and Judd (1975) are two of the most thorough investigations of lizard temperature relationships. A study of the thermal ecology of lizard species (in which all components potentiallysinfluential to the temperature status of the animal are investigated) is important in the understanding of reptilian ecology and behavior. Little is known of the flexibility of thermoregulatory responses in the face of changing weather, or different conditions imposed by geographic locality. . G. wislizeni are exposed to variable climatic conditions temporally and geographically. The comparison of mean body temperature and the range of body temperatures of the species at latitudinal extremes or daily and seasonally within a population may indicate flexibility in thermoregulation. The present study was designed 1) to investigate many of the components potentially influential to the thermal ecology of G. wislizeni, 2) to elucidate the thermal preference of the species, and 3) to assess the temperature levels important to the ecology, behavior and physiology of the species.

There is considerable published information on lizard movement, but little of it is complete for any 
species. Numerous methods are employed to investigate movement. However, there is some confusion regarding the use and interpretation of these methods. Using a collection of sighting or recapture points, each method makes a particular measurement of movement. Where the animal travels between sightings or captures is unknown. Therefore all methods provide only limited estimates of range. Undoubtedly continuous observation is the best estimator of movement. My collection of data on movement was designed 1) to investigate the home range area occupied by different lizards and determine if home range"size varied according to stage of maturity and sex; 2) to observe hourly movement of lizards and determine what variables influence distance traveled; and 3 ) to investigate the extent to which movement is random in the species.

Study Area

Studies were conducted in the southern one-third of Harney County, Oregon. The following remarks are taken from Baldwin (1964). The region constitutes the northern extreme of the basin-range province, and is characterized by north trending fault block mountains and basins of internal drainage. Prominant geological features include Steens Mountain, Pueblo Mountains, Trout Creek Mountains, Alvord Basin and Catlow Valley. The Steens, Pueblo and Trout Creek Mountain uplifts are probably of Miocene origin. These mountains, rising as much as 1500 meters above 
the valley floor, sandwich the elongate Alvord Basin. The floor of the basin averages more than 1200 meters above sea level. To the north the basin forms the:Alvord Desert, a dry clay encrusted playa ranging from 130 to 160 square kilometers. The area from about Andrews south into Nevada comprises an alkaline shrub community (The Afvord Valley). To the west of Steens Mountain is the high Catlow Valley. During the summers of 1974 and 1975 I studied G. wislizeni in the Alvord Basin and Catlow Valley (Figure 2). In both summers several field trips were made to localities throughout the Alvord Basin - Mickey Hot Springs, East Alvord Desert, Borax Lake, Fields, Trout Creek Junction, and Red Point Ranch (Figures 3 and 4). A single trip was made to the dunes near Skull Creek in the Catlow Valley in 1975 (Figure 5). A permanent study site was established at Frog Spring along the Western edge of the Alvord Desert in 1974. The bulk of the study, including all investigation of movement, occurred at Frog Spring.

Frog Spring is located about 8 kilometers north of Andrews, at $42.50^{\circ} \mathrm{N}$ latitude and $118.53^{\circ} \mathrm{W}$ longitude. The site is situated on a gradual, uniform east-facing slope of less than $10^{\circ}$ inclination. Elevation at mid-site is approximately 1225 meters. The limits of the site were chosen to enclose optimum habitat for G. wiolizeni. Suboptimum habitat surrounds most of the site. Immediately to the west shrub cover is dense and slope approaches $60^{\circ}$ 


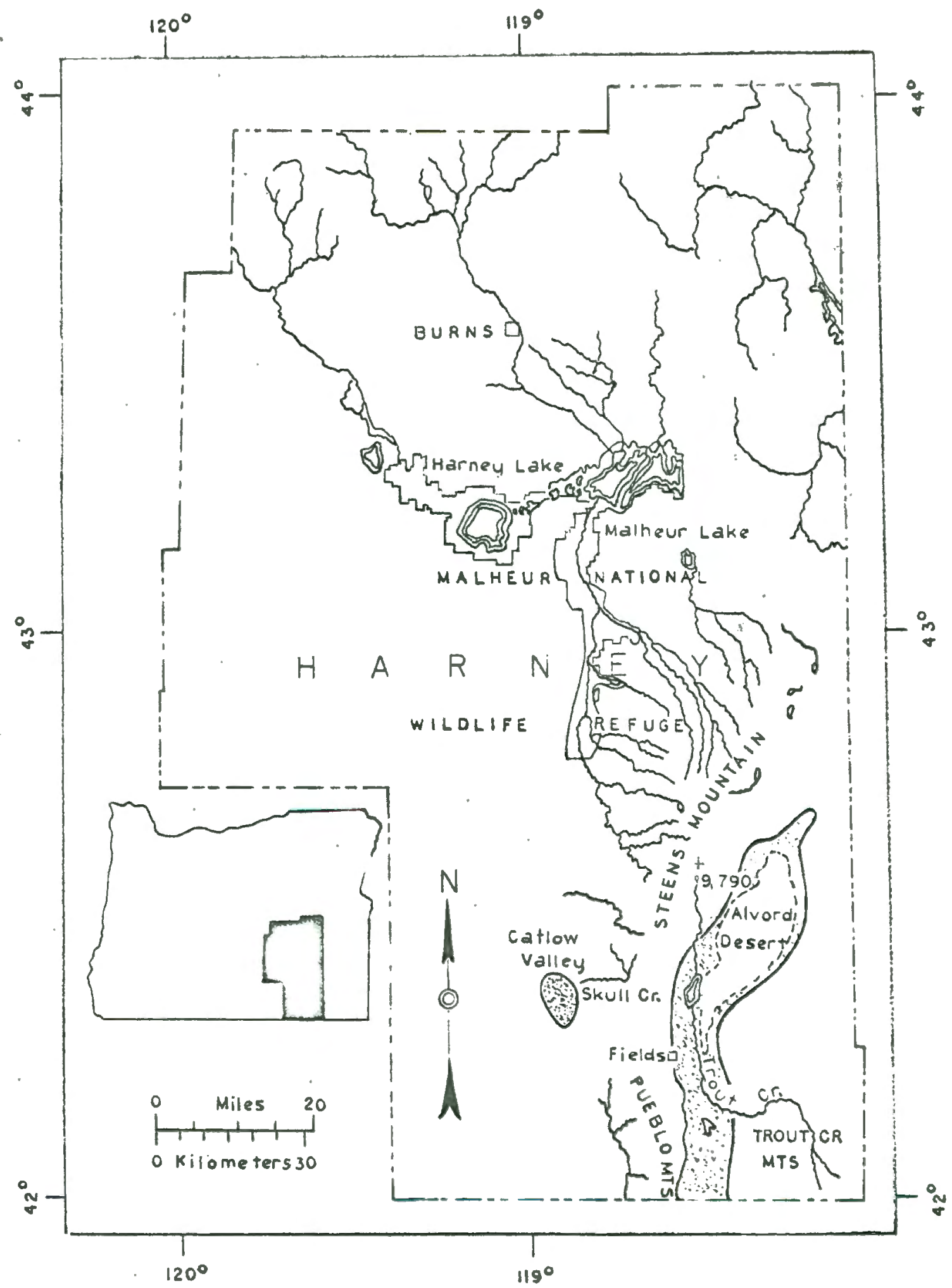

Figure 2. The distribution of Cambelia wioliseni in Harney County, as in-
dicated by the shading. 


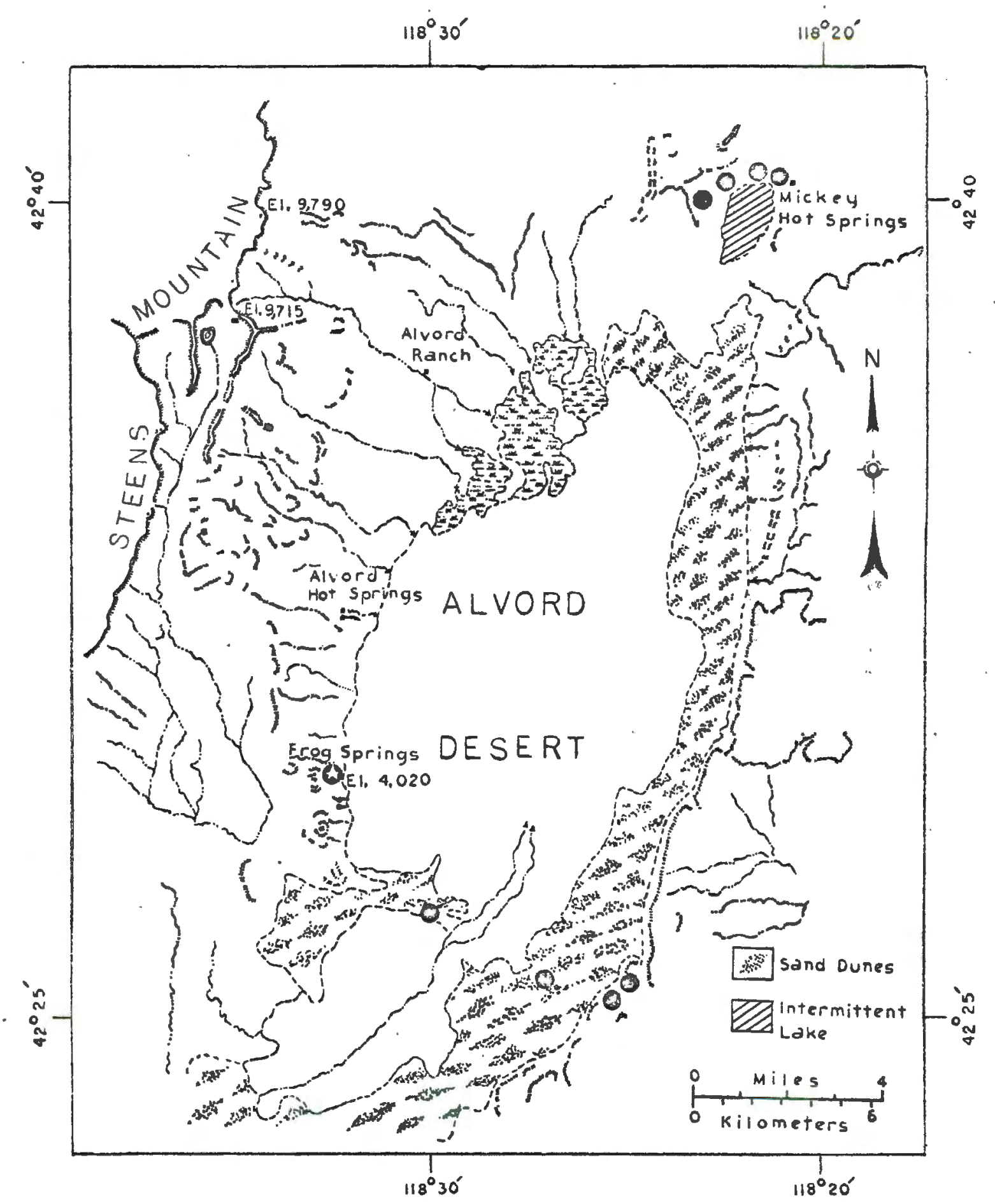

Figure 3. Alvord Desert region. Dots indicate field trip localities. Dot with star indicates Prog Spring study site. 


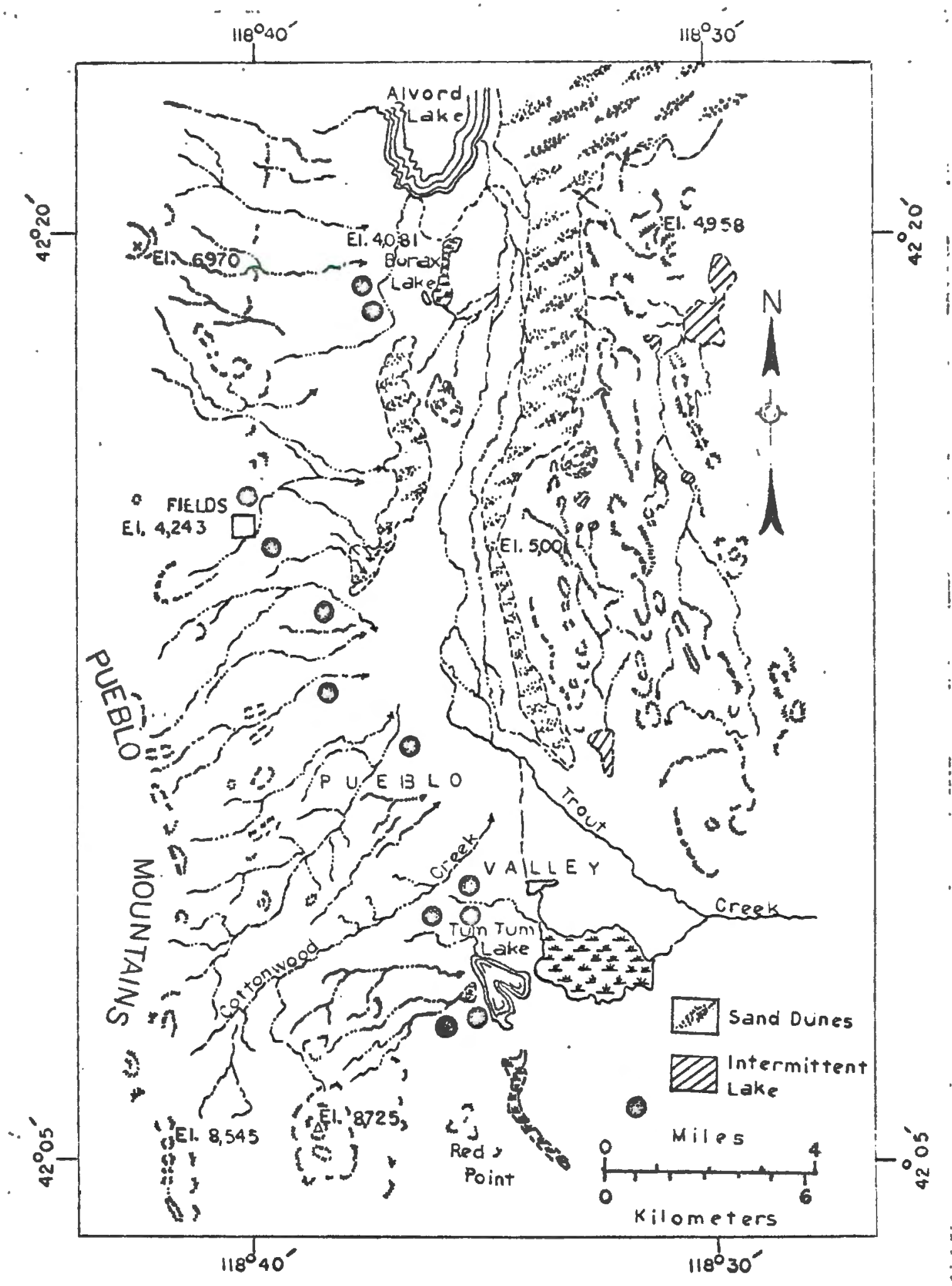

Figure 4. Pueblo Valley. Dots as in Figure 3. 


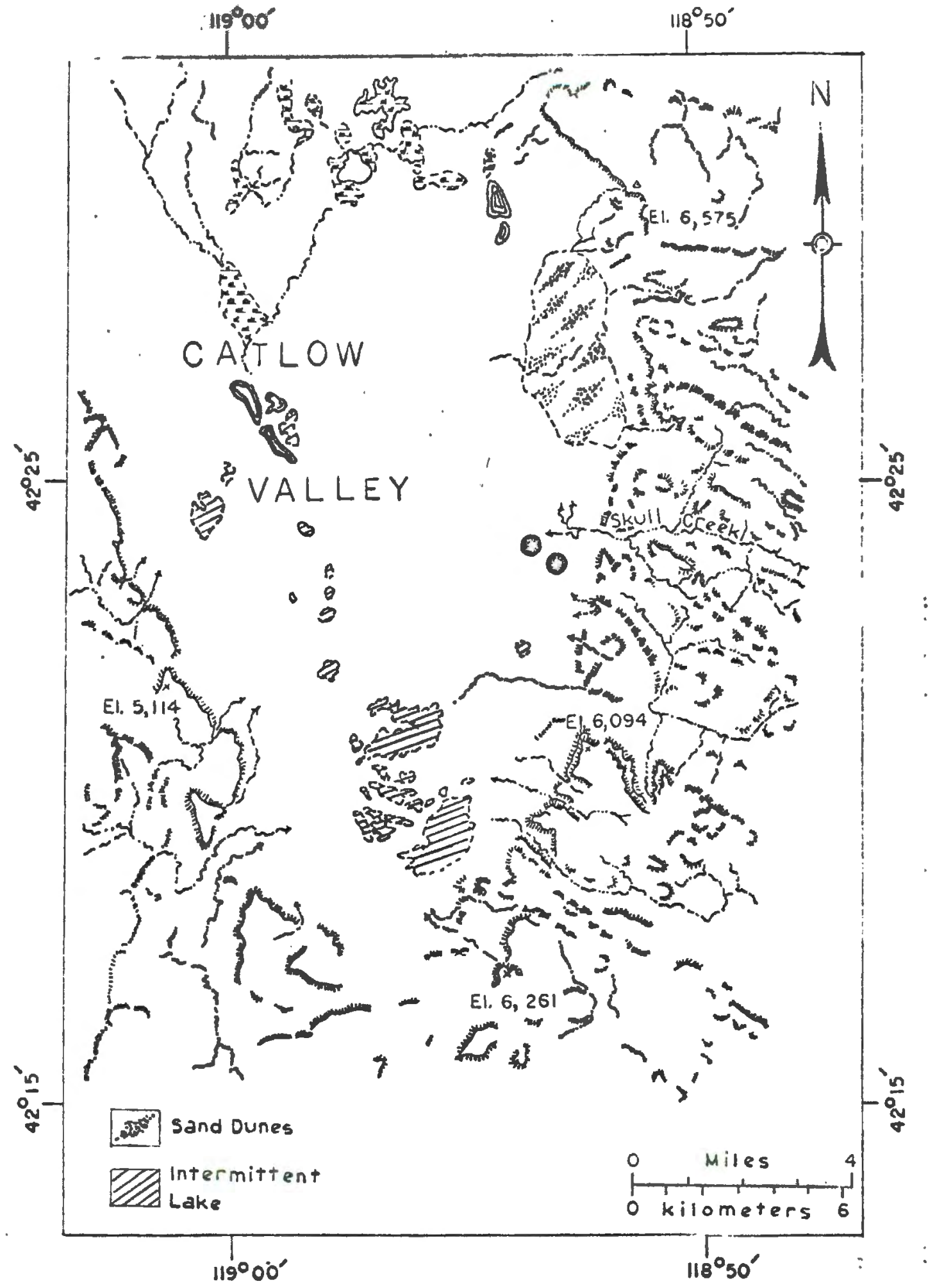

Figure 5. Catlow Valley, Dots as in Figure 3. 
inclination. The east boundary rests near the edge of the alkaline-encrusted Alvord Desert. Water from Frog Spring causes marshy conditions to occur to the north. Dense stands of shrubs and grasses project finger-like extentions into the site at the south boundary. The site itself forms a rectangle; east-west boundaries, are 182.93 meters, and north-south boundaries are 152.44 meters.

Soil on most of the site is loose and sandy, with scattered rocks up to 15 centimeters in diameter. Toward the Alvord Desert there are gravelly, clay-encrusted areas up to 10 meters in diameter.

Plant cover was determined by using a table of random numbers to select locations for transects across individual quadrats. Each quadrat was defined by subdivision of the total area into thirty 30.49 meter square plots. Plant cover is approximately $54 \%$. Shrubs contribute $22 \%$ of the total cover with sarcobates vermiculatus (greasewood) comprising 12\%, Artemeoia tridentata (sagebrush) 4\%, Chryoothamnus viscidiflorus and $c$. nauseosus (rabbitbrush) $3 \%$, and Atriplex confertifolia (shadscale) $2 \%$. Other shrubs on the site include Artemesia spinescens (Budsage), Tetradymia spinosa (cotton thorn horsebrush), T. glabrata (Little leaf horsebrush), T. canescens (Gray horsebrush), Graya spinosa (Spiny hopsage), and Elaeagnus angustifolia (Russian olive). Grasses comprise approximately $32 \%$ of the total cover. Species on the site include Bromus 
tectorum (cheat grass), Distichlis stricta (saltgrass), Festuca idahoensis (Blue bunch grass), Elymus cinerius (Great basin wild rye), and Poa sp. (bluegrass). Juncus sp. (rush) occurs along the east edge of the site. Vertebrates at Frog spring are numerous and are listed in Table 1 . 
TABLE I

VERTEBRATES SIGHTED IN VICINITY OF FROG SPRING

I. AMPHIBIANS

Hyla regilza

II. REPTILES

scoloporus graciosus Colubex constrictor

Phrynosoma platyrhinos Masticophis taeniatus

Uta stansiburiana Pituophis melanoleucus

Cnemidophorus tigris Crotalus viridis

III. BIRDS

Buteo jamaicensis Speotyto cunicularia

Cathartes aura Lanius Iudovicianus

Falco sparverius Amphispiza belli

Charadrius vociferus

IV. MAMMALS

Sylvilagus nuttalzi . Dipodomys ordii

Lepus californicus Ammospermophilus leucurus

Peromyscus maniculatus Canis Zatrans

Perognathus parvus Taxidea taxus 


\section{MATERIALS AND METHODS}

Climatological data for the study area was provided in part by the National Weather Service. 1974 and 1975 monthly temperature and precipitation records for the period in which $G$. wislizeni were active were taken from Andrews Weston Mine and Whitehorse Ranch (Table 2). These stations are 6.8 and 30.1 kilometers respectively, from Frog Spring. Yearly averages of climatological data come from Burns, located approximately 145 kilometers to the northwest. Precipitation averages 7 to 12 inches, one third falling as snow. The warmest month of the year is July (average maximum $=29.8^{\circ} \mathrm{C}$ ), and the coolest month of the year is January (average maximum $=1.9^{\circ} \mathrm{C}$ ). Nighttime frosts may occur any month of the year. High winds are frequent and strongest during spring and summer. The average summer wind velocity is approximately $11.9 \mathrm{kilo-}$ meters per hour. During the two summers spent at Frog Spring hourly air and surface temperatures were recorded from 0800 to 1800 with a Yellow Springs multi-channel telethermometer (model number for instrument is $46 \mathrm{TUC}$ and environmental probes are YSI 405 and YSI 408). Ranging from 0 to $51^{\circ} \mathrm{C}$, the instrument records to the nearest \pm $0.1^{\circ} \mathrm{C}$. At the site maximum air temperatures frequently reached the $30-40^{\circ} \mathrm{C}$ range, and sometimes exceeded $40^{\circ} \mathrm{C}$. Surface temperatures exceeding $50^{\circ} \mathrm{C}$ in the sun were common. Minimum air temperatures, recorded with a Min-Max thermometer, were generally above freezing (lowest reading of 
TABLE II. METEOROLOGICAL DATA COVERING SEASONAL PERIODICITY

\begin{tabular}{|c|c|c|c|c|c|c|c|c|c|}
\hline \multirow{3}{*}{ YEAR } & \multirow{3}{*}{ MONTH } & \multicolumn{4}{|c|}{ ANDREWS WESTON } & \multicolumn{4}{|c|}{ WHITEHORSE } \\
\hline & & \multicolumn{2}{|c|}{ TEMP. } & ${ }^{\circ} \mathrm{C}$ & \multirow{2}{*}{$\begin{array}{l}\text { TOTAL } \\
\text { RAIN- } \\
\text { FALL }\end{array}$} & \multicolumn{2}{|c|}{ TEMP. } & \multirow{2}{*}{\begin{tabular}{|l}
${ }^{\circ} \mathrm{C}$ \\
DALLY \\
AVG.
\end{tabular}} & \multirow{2}{*}{$\begin{array}{l}\text { TOTAL } \\
\text { RAIN- } \\
\text { FALL }\end{array}$} \\
\hline & & $\begin{array}{l}\text { AVG. } \\
\text { MAX. }\end{array}$ & $\begin{array}{l}\text { AVG. } \\
\text { MIN. }\end{array}$ & $\begin{array}{l}\text { DAILY } \\
\text { AVG. }\end{array}$ & & $\begin{array}{l}\text { AVG. } \\
\text { MAX. }\end{array}$ & $\begin{array}{l}\text { AVG. } \\
\text { MIN. }\end{array}$ & & \\
\hline \multirow[t]{6}{*}{1974} & MAY & 17.7 & 5.3 & 11.5 & 1.20 & 20.2 & 2.2 & 11.2 & 0.30 \\
\hline & JUNE & 27.5 & 13.3 & 20.4 & 0.13 & 28.4 & 7.7 & 18.1 & \\
\hline & JULY & 29.2 & | 4.4 & 21.8 & 3.50 & 30.1 & 10.0 & 20,3 & 1.30 \\
\hline & AUGUST & 28.5 & 14.3 & 21.4 & $0.07 \mid$ & 29.4 & 8.8 & 19.1 & 0.36 \\
\hline & SEPTEMBER & 26.4 & 11.5 & 18.9 & 0.00 & 27.0 & 4.4 & 15.7 & 0.00 \\
\hline & OCTOBER & 17.5 & 4.4 & 11.0 & 1.90 & 18.4 & -0.6 & 8.9 & 4.10 \\
\hline \multirow[t]{5}{*}{1975} & MAY & 17.2 & 4.4 & 10.9 & 1.50 & $\mid 9.7$ & 0.8 & 10.3 & 0.69 \\
\hline & $\begin{array}{l}\text { JUNE } \\
\text { JULYY }\end{array}$ & $\begin{array}{l}22.2 \\
30.7\end{array}$ & $\begin{array}{l}8.6 \\
16 . ?\end{array}$ & $\begin{array}{l}15.4 \\
23.4\end{array}$ & 2.80 & $\mid \begin{array}{l}24.4 \\
30.8\end{array}$ & $\begin{array}{l}5.4 \\
1.9\end{array}$ & $\begin{array}{l}14.9 \\
21.4\end{array}$ & $\begin{array}{l}1.90 \\
0.76\end{array}$ \\
\hline & AUGUST & 26.0 & 2.1 & 19.1 & 4.90 & 26.5 & 8.0 & 17.3 & 2.60 \\
\hline & SEPTEMBER & 25.7 & 11.1 & 18.4 & 0.23 & 25.9 & 3.7 & 14.8 & 0.05 \\
\hline & OCTOBER & 15.1 & 3.8 & 9.4 & 7.30 & 17.0 & 2.2 & 9.6 & 2.90 \\
\hline
\end{tabular}


$0^{\circ} \mathrm{C}$ occurred on 25 June 1975).

Between 8 July and 20 August 1974, and 20 June and 11 August 1975, a total of 50 days were spent, in the field. G. wislizeni were captured with a noose made of $141 \mathrm{~b}$ test line attached to a fishing rod extensible to 8 feet. Capture methods involved slowly walking transects over designated areas. When a lizard was seen, careful stalking was required to get close enough to use the noose. Many individuals which had been captured several times, became wary of the noose, making capture more difficult. On field trips, lizards were frequently seen from an automobile, and then pursued on foot.

When G. wislizeni were captured their body temperature [ $\left(\mathrm{T}_{\mathrm{b}}\right)$ (Probe model number YSI 406] and environmental temperatures were recorded at once with the aid of a telethermometer. Recorded environmental temperatures include air temperature 30 centimeters above sand surface in shade of a shielding device $\left(\mathrm{T}_{\mathrm{ASH}}\right)$, sand temperature in shade of nearest vegetation ( $\left.\mathrm{T}_{S S H}\right)$, and sand temperature in sun ( $\mathrm{TSSN}_{\mathrm{S}}$ ). In taking sand temperatures, the tip of the thermistor was inserted at an angle so as to be covered by a couple millimeters of sand. To avoid investigator influence on body temperature, lizards were handled with gloves or by thumb and index finger on a line passing dorsoventrally through the pectoral girdle region. The lizard's sex, the date and time of capture, and behavior 
prior to capture were recorded. Lizards were then taken to the car for measurement of weight, snout-vent, limb, and tail length, and head dimensions. Femoral pores were counted on both hindlimbs. Lizards were examined thoroughly for injuries, scars, deformitites, and ectoparasites. All lizards were released at the point of first sighting.

At Frog Spring lizards were identified in the following manner. A color code represented by plastic flagging, was assigned to each lizard. The flagging was fastened along with a tag (showing time and date of sighting) to a garden stake. The stake was driven in the ground at the point where the lizard was first sighted. This procedure occurred every time a sighting was made. For quick identification numbers were placed on the dorsum of each captured lizard with white water base paint. Painted numbers remained distinct between molts. Permanent identification was accomplished by hot-branding numbers on the venter with a fine aluminum wire. Great care taken to avoid extensive scarring.

At Frog Spring on 24 and 25 July 1975, between 1200 and $1500 \mathrm{H}, 25$ lizards were tethered to study heat stress. One end of a four foot piece of size 50 sewing thread was fastened to a wooden garden stake and the other end made into a loop to be fitted over the lizards trunk just anterior to the hindlimbs. Tethering sequence for each lizard involved 1) an initial five minute period where the 
stake was driven in a spot which allowed the lizard to select an area of choice (shade, broken shade, or sun), 2) staking in the sun until the onset of panting occurred, and 3) a five minute period in which the stake was returned to where the lizard could again select an area of choice. Body and environmental temperatures were recorded at the end of each of these events.

A the rmal gradient chamber was used indoors to investigate the thermal preference of G. wislizeni. An adult male and female were selected for study. The cage, $3 \mathrm{ft}$ $x 16$ in $x 16$ in, was constructed with 1 inch pine and $1 / 4$ inch plywood. All sides were covered with plywood except one of the long sides which supported a panel of $1 / 8$ inch glass. Two openings were provided on the top near the ends and covered with $1 / 4$ inch plywood lids. Inside the bottom was covered with 2 , cm of sand, upon which rested a few rocks and dishes containing food and water. The lizards were fed mealworms (Tenebrio sp.) or grasshoppers (Mézanoplus sp.) every third day. A 60 watt incandescent light. was positioned above the chamber's center and regulated on a 12 hour light-dark cycle at all times. The light was on for the period 0800 to $2000 \mathrm{H}$. A 250 watt infrared light was positioned over one of the openings, about $50 \mathrm{~cm}$ above the sand surface. The I.R. light was turned on simultaneously with the incandescent lamp for 4-6 hours each day during two four day study periods. The initial study 
period occurred on 25 through 28 october 1975. The second study period occurred on 16 through 19 December 1975. Thermistor leads were placed within the chamber, one remaining accessible for cloacal recordings. Along with body temperatures of the two lizards the following chamber environmental temperatures were recorded: air temperature at the infrared end $\left(\mathrm{T}_{\mathrm{AIR}}\right)$; air temperature at the end opposite the infrared $\left(\mathrm{T}_{\mathrm{AOE}}\right)$; sand temperature directly under the infrared lamp ( $\left.\mathrm{T}_{S I R}\right)$; sand temperature in the middle of the chamber $\left(\mathrm{T}_{S M C}\right)$; and sand temperature at the end opposite the infrared $\left(\mathrm{T}_{\mathrm{SOE}}\right)$. Environmental temperatures were recorded every 15 minutes. Cloacal temperatures for each lizard were recorded every 30 minutes.

The ninety-five percent level of confidence has been accepted for the results of all statistical analyses, A multiple regression was used to analyze the effect of various components on $\mathrm{T}_{\mathrm{B}}$. This method provided information on the effect of each component separately (correlation of $x$ vs $y$ ), and the effect of each component adjusted for al1 others (computed $\mathrm{T}$ value). Using the standardized normal (z statistic), values are considered significant for correlation of $x$ vs $y$ and computed $-T$ if they exceed \pm .361 and \pm 1.96 , respectively.

From field data, diel activity was assessed from recorded time (Pacific Standard Time) for each lizard sighting. From the data I calculated the average number of 
lizards sighted per man hour of effort.

Three methods of calculation were used to interpret movement in Gambelia: 1) minimum area (Tinkle, 1962); 2) distance traveled per hour (Irwin, 1965); and 3) mean direction and circular variance (Mardia, 1972). In the first method, outcrmost points of plotted coordinates for 33 lizards were connected to enclose convex polygons whose areas were then measured. These areas defined the minimum home range. In the distance traveled per hour method, using binoculars when necessary, 57 movements of marked free-ranging lizards were observed from distances of 15 meters or more. Stakes were placed on the ground to fix points at which lizards changed direction. Later the stakes were driven into the ground and flagged and tagged in the manner described above. Distances between each successive stake, from first to last, were then measured and summed to obtain total distance traveled. With the mean direction and circular variance method, an attempt was made to predict the extent of randomness in movement. This was accomplished by plotting angles of two successive movements on a circle, and computing the mean direction and circular variance, for adult males; adult females, and juveniles. 


\section{RESULTS}

Seasona1 Periodicity

In Harney County, seasonal emergence of G. wislizeni is somewhat later than other lizard species. I have observed active individuals throughout May. Denzel Ferguson (personal communication) believes that under favorable weather conditions emergence might occur in late April. Seasonal activity begins with reproduction. The peak of reproductive activity appears to be late May and early June. At Frog Spring, on 31 May 1975, several separate adult males were observed in the company of one or more adult females in the shade of Sarcobates vermicuzatus. Females develop nuptial orange coloration at approximately the time of ovulation. Copulation probably occurs when or just before this coloration appears (Tanner and Krogh, 1974). Most females have deposited their eggs by the end of June. The latest capture of a female still possessing oviducal eggs occurred near Mickey Hot Springs on 27 June 1975. This individual displayed elaborate nuptial orange on labial, pre- and postocular, supraocular, and loreal head scales; gular and neck folds, lateral trunk, portions of the limbs, and ventral side of tail from base to.tip, and she weighed $49.7 \mathrm{~g}$. After egg-laying, nuptial coloration gradually fades, but remains discernible in some individuals in late summer. Infrequent copulations between adults of opposite sex were observed in July, the latest occurring on the $18 \mathrm{th}$ in 1975. The significance of this late reporductive 
behavior is unclear. G. wislizeni are quite abundant through July. At Frog Spring, adult males were sighted in declining numbers after the first week in August. The frequency of adult female sightings began to decline in early August too, but at a more gradual rate. Frank Sheets (personal communication) has observed adult females active as late as mid-September. Montanucci (1967) offers a physiological explanation for the seasonal difference in retreat of adults of each sex. Apparently, activity in $G$. wislizeni remains quite high until sufficient storage of paired fat bodies is accomplished. Early in the season adult females use much of their food intake for egg development. Consequently, after egg-laying their stored fat is greatly depleted. In order to make up the deficit, some individual females must remain active much later in the season than males. The earliest sighting of a hatchling took place on 7 August 1974 near Trout Creek Junction. At Frog Spring, hatchlings were not seen until 18 August 1974, and were abundant on the days immediately following. The weather during the summer of 1975 was quite different from that of the previous summer. I suspect annual weather fluctuations may cause considerable variation in the time of hatching. The young of a given year remained active into the fall. In 1974 Mark Smith (personal communication) observed them as late as 15 October at several locations on The Alvord Basin. 
Diel Activity

Figure 6 shows accumulated data on the times of all sightings made in July and August 1974 and June, July, and August 1975. Daily activity patterns varied with loçal climatic conditions. Perhaps daily activity varies seasonally too, but this aspect was not investigated in the study. During the summer, on warm sunny days, G. wistizeni exhibited a bimodal pattern of daily activity. Despite high temperatures and intense solar radiation, some activity occurred at all hours between 0600 and 1800 .

On only two occasions were G. wislizeni sighted pefore $0700 \mathrm{H}$. The earliest sighting, $0653 \mathrm{H}$, occured at a shaded air temperature $\left(\mathrm{T}_{\mathrm{ASH}}\right)$ of $29.4^{\circ} \mathrm{C}$, and a sunny sand surface temperature ( $\mathrm{T}_{\mathrm{SSN}}$ ) of $30.4^{\circ} \mathrm{C}$. Emergence on warm sunny mornings usually occurred between 0700 and $0800 \mathrm{H}$. On cool and/or overcast mornings, emèrgence was more likely to occur between 0800 and $0900 \mathrm{H}$. Even during weather conditions bordering on the minimum extreme for activity, $G$. wislizeni were usually sighted at the entrance of burrows or just under branches of shrubs by shortly after $0900 \mathrm{H}$. Air temperature not exceeding $13-15^{\circ} \mathrm{C}$ coupled with sand surface temperatures of no greater than $21-23^{\circ} \mathrm{C}$ inhibited most emergence. One sunny morning an individual was sighted at 0725 when $\mathrm{T}_{\mathrm{ASH}}$ was $14.5^{\circ} \mathrm{C}$ and $\mathrm{T}_{S S N}$ was $21.4^{\circ} \mathrm{C}$. During the summer's coldest weather, if sufficient solar radiation was present to elevate sand temperatures above the critical 


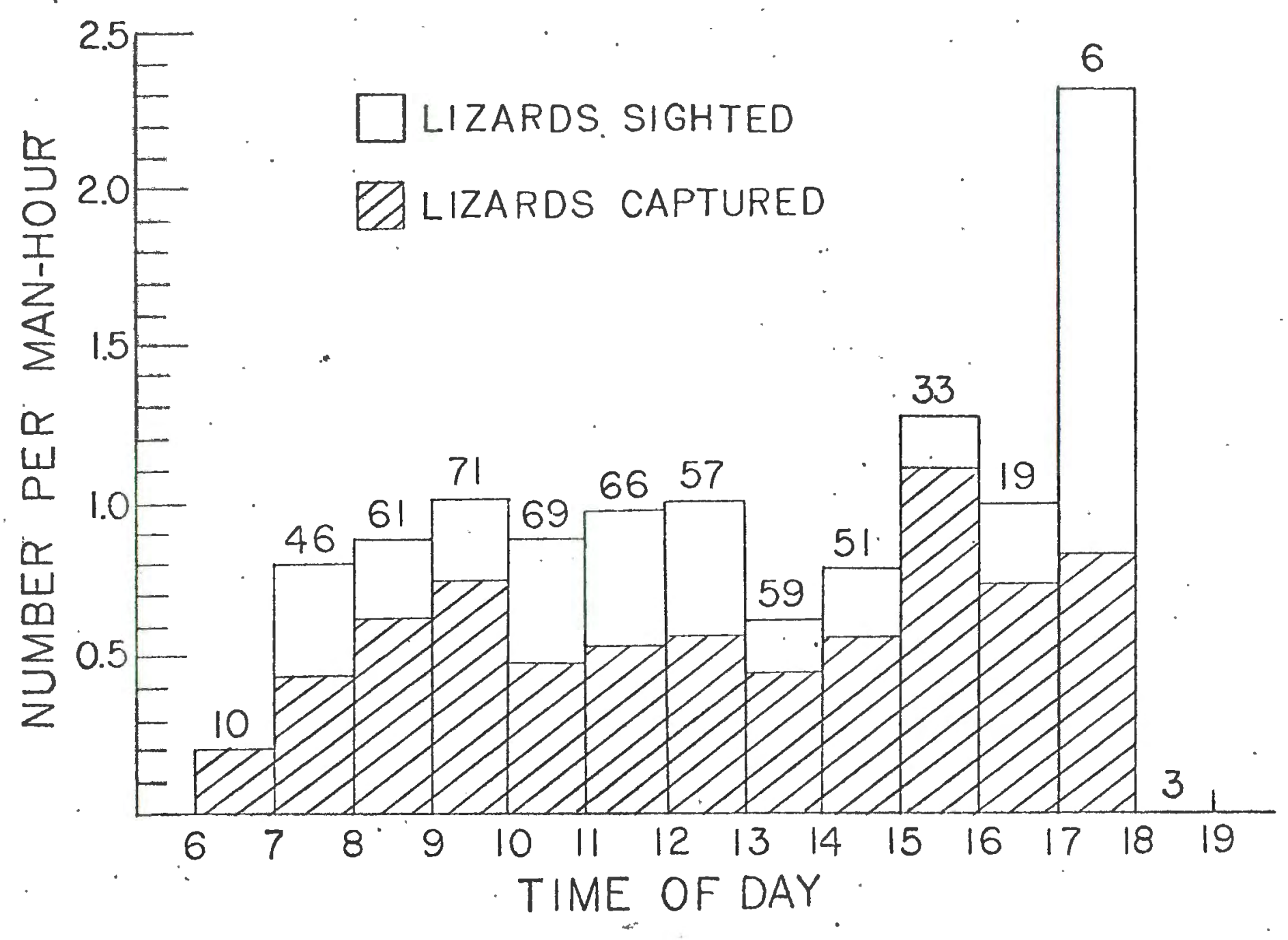

Figure 6. Diel activity of Gambelia wislizeni. Numbers above the bars represent the number of man-hours spent at a given hour of the day. 
level stated above, emergence would occur anytime throughout the morning. On 25 June 1975 the first lizard sighted occurred at $1150 \mathrm{H}$ when $\mathrm{T}_{\mathrm{ASH}}$ and $\mathrm{T}_{\mathrm{SSN}}$ were 13.0 and $28.3^{\circ} \mathrm{C}$ respectively. Seemingly, the emergence of G. wislizeni is largely influenced by environmental temperatures (especially sand surface), and to a lesser extent by other factors (probably photoperiod).

On warm sunny days retreat usually occurred between 1700 and $1800 \mathrm{H}$, activity abruptly ceasing about $1730 \mathrm{H}$. The latest sighting of G. wislizeni above ground was 1737 H. For most, cool to moderate or cloudy weather hastened retreat by an hour, but under these conditions several lizards were observed disappearing into burrows at all hours of the afternoon. At a $\mathrm{T}_{\mathrm{ASH}}$ of $28.4^{\circ} \mathrm{C}$ and a $\mathrm{T}_{S S N}$ of $48.4^{\circ} \mathrm{C}$, one individual crawled into a self-made burrow at $1309 \mathrm{H}$. The reason for early retreat in these few individuals is not evident. Air and sand surface temperatures at times of retreat were variable, but usually registered well above minimum levels for activity. It would appear biological rhythm (probably in response to photoperiod) and physiological state (such as feeding satiation) largely influence time of retreat.

In summer juveniles also exhibit a bimodal pattern of diel activity, and were found at all hours in which adults were encountered. At times of high environmental tempera-.. tures and intense solar radiation they were frequently more 
active than adults. About 5 kilometers south of Fields, on a warm day, a search at a locality supporting numberous $G$. wislizeni produced only one juvenile. Observed in complete shade at $1120 \mathrm{H}$, the $\mathrm{T}_{\mathrm{ASH}}$ and $\mathrm{T}_{\mathrm{SSN}}$ respectively registered 33.5 and above $51.0^{\circ} \mathrm{C}$. In autumn, under favorable weather conditions, juveniles were most active at midday (Mark Smith, personal communication).

Strong, steady and sometimes gusty southerly to southwesterly winds were frequent at Frog Spring, and usually were associated with reduced $G$. wislizeni activity. Light breezes, prevailing almost continuously, had little effect on activity. Overcast conditions reduced activity at all temperatures. A combination of cool and/or overcast and very windy conditions reduced activity markedly. Rain, even a brief thunder shower, caused immediate cessation of activity. However, if the sand was relatively dry, normal activity usually resumed on days following most rains.

Effect of Environmental Temperatures on Body Temperature

The mean body temperatures of active G. wistizeni were always higher than the mean temperature of the shaded air (Figures 7 and 8 ). In fact $94.3 \%$ of all individual values were higher (Figure 9). The relationship of body temperature $\left(\mathrm{T}_{\mathrm{B}}\right)$ to substrate temperature showed more variability (Figures $7,8,10$ and 11 ). During the first hour of activity, mean $\mathrm{T}_{B}\left(34.4^{\circ} \mathrm{C}\right)$ was slightly higher than mean $\operatorname{TSSN}\left(33.5^{\circ} \mathrm{C}\right)$ and markedly higher than mean TSSH 


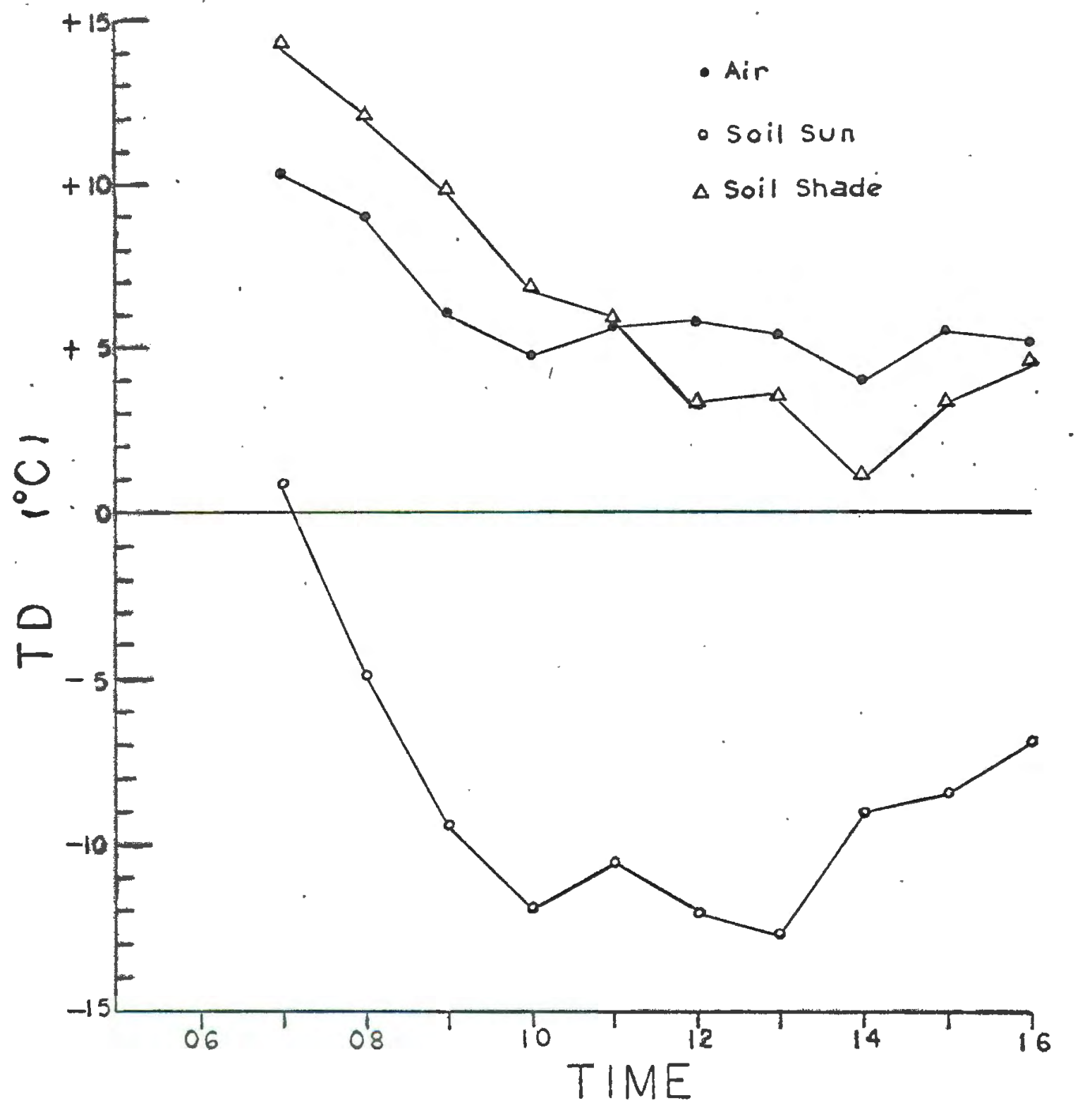

Figure 7. Daily course of mean difference in temperature (TD) between Gambelia wislizeni and selected environmental readings.

Soil sun = Least probably mean (see Figure 8). 


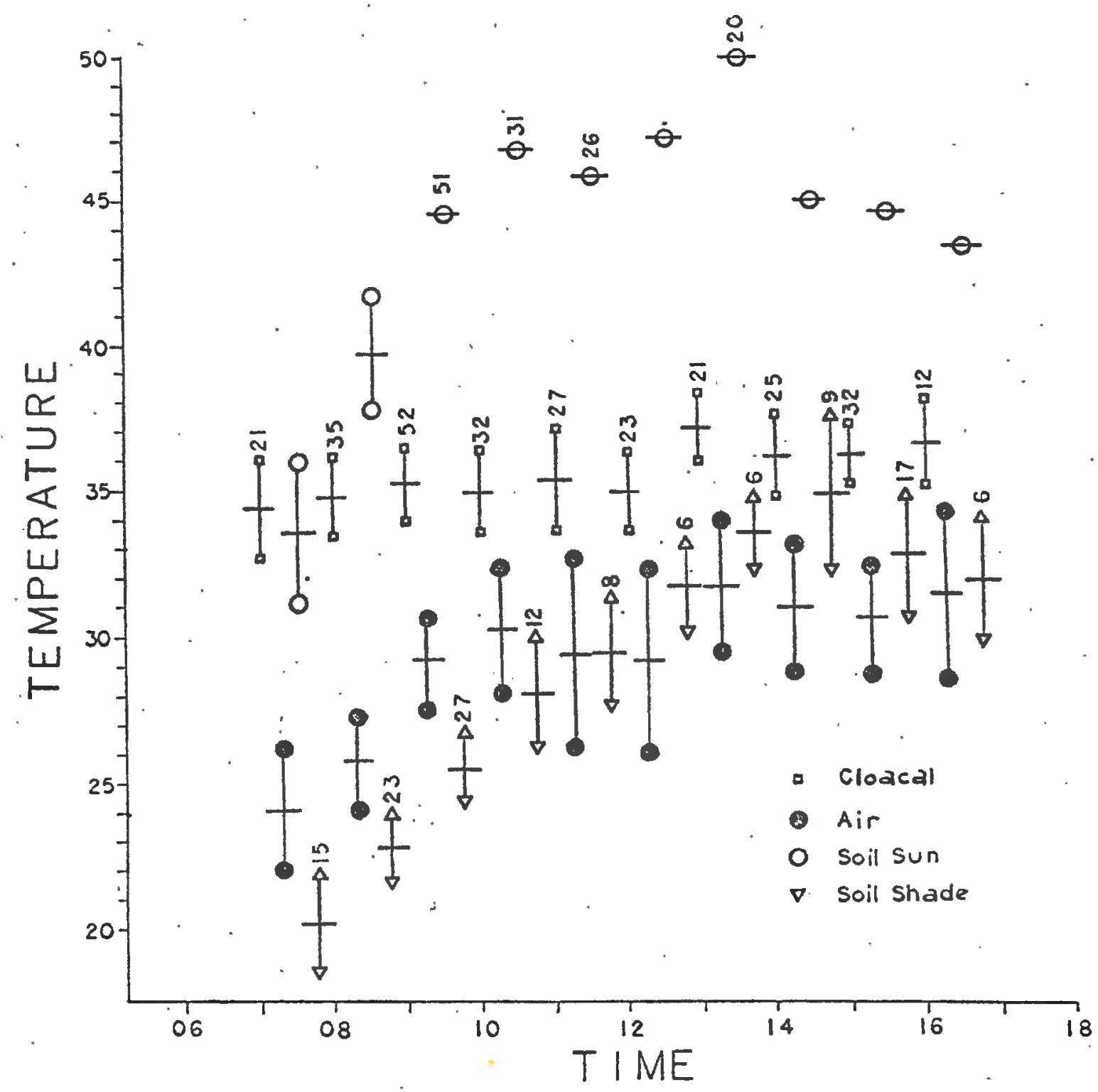

Figure 8. Comparison of Gambelia wislizeni body temperatures and environmental temperatures. Vertical distance between geometeric symbols $=95 \%$ confidence intervals for respective temperatures. Horizontal lines indicate mean temperatures. Sample sizes for environmental temperatures are the same as for body temperatures unless otherwise indicated. Soil sun values exceeding the upper limit of the instrument were as signed the maximum measurable temperature $\left(51^{\circ} \mathrm{C}\right)$ and the least probable mean calculated. All temperatures are in degrees celsius. 


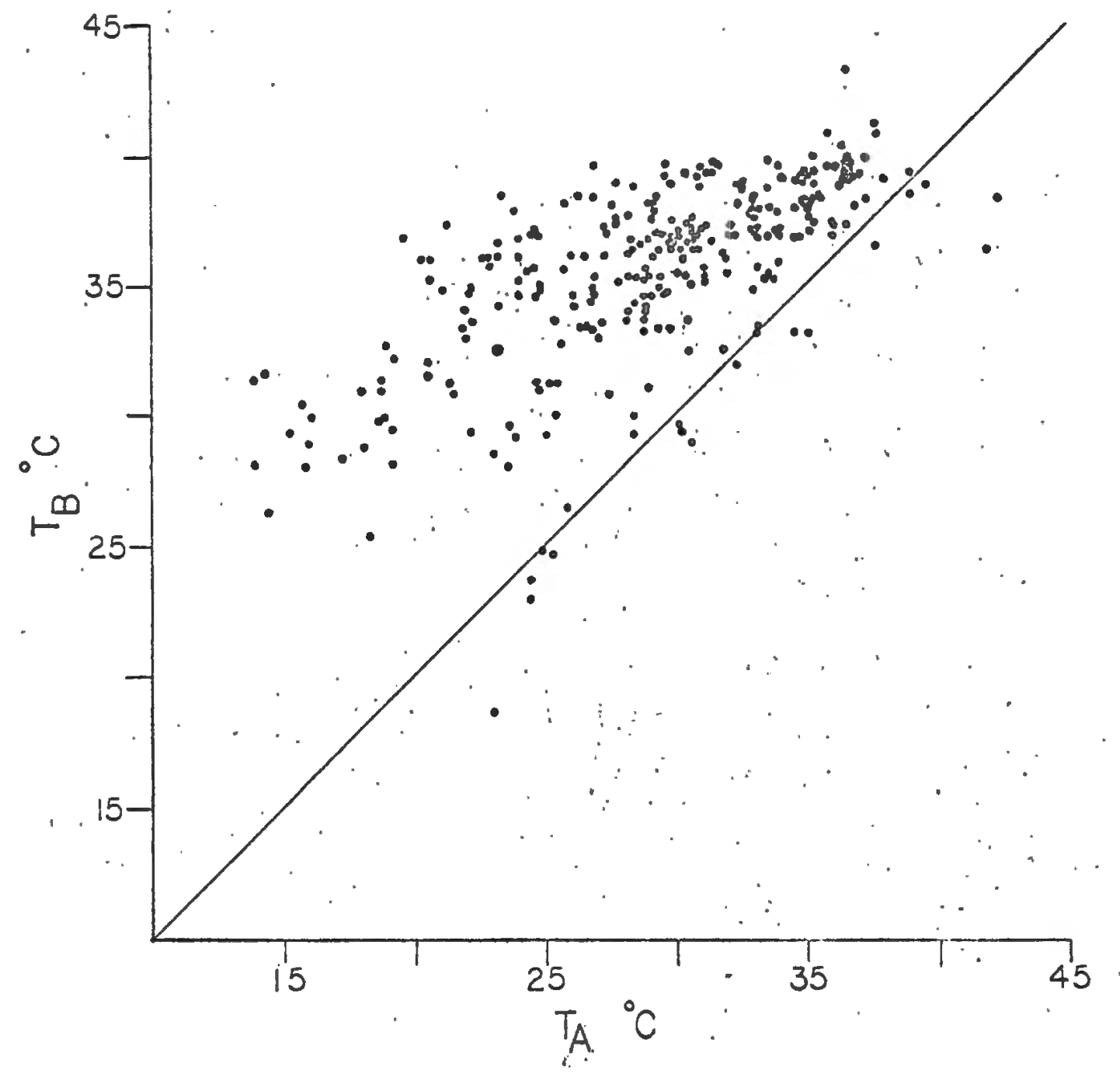

Figure 9. Relationship of body temperature $\left(\mathrm{T}_{B}\right)$ of Gambelia wialiseni to shaded air temperature ( $\mathrm{T}_{\mathrm{ASH}}$ ). Large dots represent two identical values. Is othermal line noted for reference. 


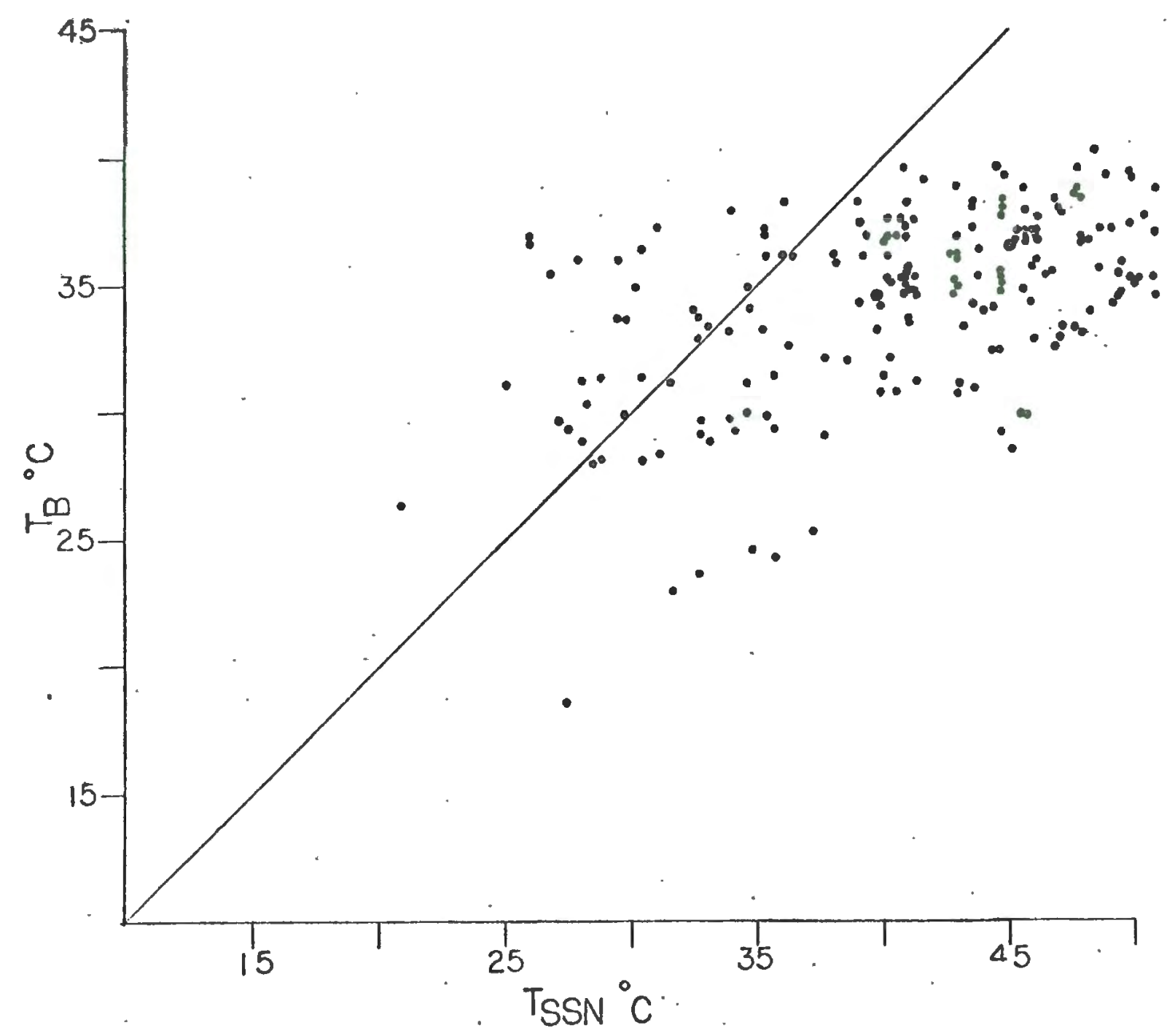

Figure 10. Relationship of body temperature $\left(\mathrm{T}_{B}\right)$ of Gambelia wislizeni to sunsoil temperature (TSSN). 


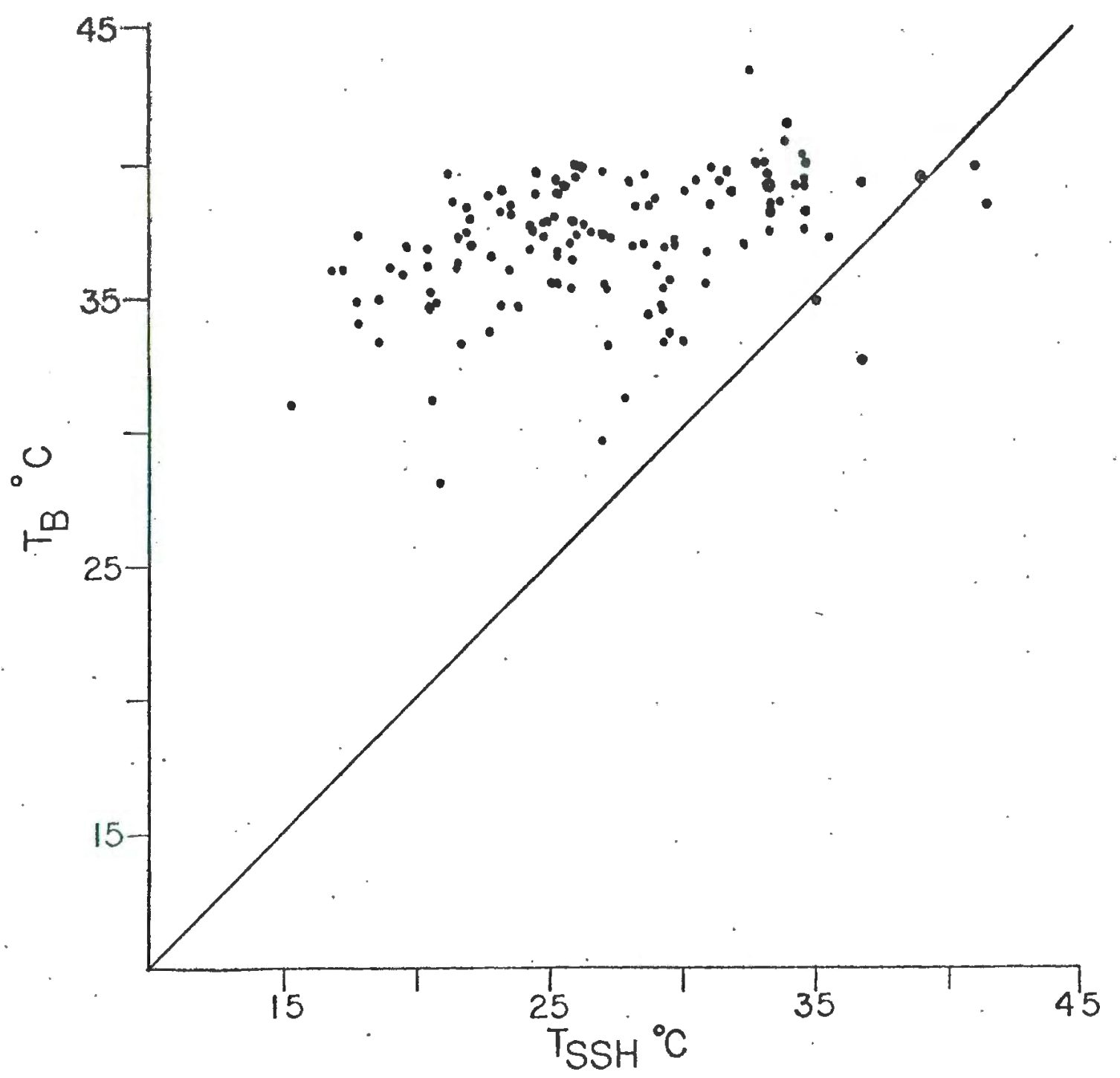

Figure 11: Relationship of body temperature $\left(T_{B}\right)$ of Gambelia wiszizrni to shaded soil temperature $\left(\mathrm{T}_{\mathrm{SSH}}\right)$. 
$\left(20.1^{\circ} \mathrm{C}\right)$. After $0800 \mathrm{~T}_{S S N}$ usually warmed rapidly and for the entire activity period was found to exceed $T_{B} 88.9 \%$ of the time. Ninety-nine percent of the individual values for $\mathrm{T}_{\mathrm{SSH}}$ were below $\mathrm{T}_{\mathrm{B}}$.

From emergence to about $0900 \mathrm{H}$ (later on cool days) many G. wistizeni were found in full sunlight at the base of shrubs and in open areas. By $0900 \mathrm{H}$ most individuals achieved a $T_{B}$ within the active range and began to move about and feed. Mean $\mathrm{T}_{\mathrm{B}}$ at $0900 \mathrm{H}$ was $35.2^{\circ} \mathrm{C}$, hourly mean $\mathrm{T}_{\mathrm{B}}$ remained close to this value until $1300 \mathrm{H}$.' During the hour 1000 to $1100 \mathrm{~T}_{S S N}$ usually reached upper $40^{\prime} \mathrm{s}{ }^{\circ} \mathrm{C}$ and frequently exceeded $50^{\circ} \mathrm{C}$. These temperatures are above physiological tolerance for many species of iguanid lizards (Mosauer, 1936; Cowles and Bogert, 1944; Lowe and Vance, 1955; Larson, 1961; Heatwole, 1970; Lashbrook, 1970; and Judd, 1975). Shade at the base of shrubs offered some relief from the harsh thermal conditions of open areas. Mean $\mathrm{T}_{\mathrm{ASH}}$ and $\mathrm{T}_{\mathrm{SSH}}$ for the hour 1000 to 1100 were 30.1 and $28.0^{\circ} \mathrm{C}$, respectively. During the period 1000 to $1300 \mathrm{H}$ activity was high, but ventures into the open became shorter in duration. From 1300 to $1400 \mathrm{H}$ solar radiation reached maximum intensity, and this condition is largely responsible for a marked change in $\mathrm{T}_{B}$ and environmental temperatures. During this hour TSSN almost always exceeded $50^{\circ} \mathrm{C}$. Mean $\mathrm{T}_{\mathrm{ASH}}$ and $\mathrm{T}_{\mathrm{SSH}}$ for the hour were respectively 31.8 and $33.8^{\circ} \mathrm{C}$. Mean hourly $\mathrm{T}_{\mathrm{B}}$ for 1200 to 1300 was $34.9^{\circ} \mathrm{C}$ 
and for 1300 to 1400 was $37.2^{\circ} \mathrm{C}$, a significant difference $(t<2.4045, P<0.02)$. Activity for this period was usually much reduced. From 1300 to $1500 \mathrm{H}$ TSSH usually registered lower to mid-30's ${ }^{\circ} \mathrm{C}$, but occasionally reached $40^{\circ} \mathrm{C}$. Elevated $\mathrm{T}_{\mathrm{SSH}}$ narrowed the range in soil temperatures and increased the mean soil temperature making it difficult for $G$. wislizeni to maintain $T_{B}$ within a tolerable range. During these stress periods several indiduals spent much time perched on top of shrubs, perhaps in an effort to escape high environmental temperatures, but remain above ground. Here mean hourly TASH never exceeded $31.8^{\circ} \mathrm{C}$. Many individuals spent the warmest portion of the day below, ground, retreating to the cooler environment present in burrows. Shortly after $1500 \mathrm{H}$, with reduced solar radiation and subsiding environmental temperatures, lizard activity. greatly increased. Lower TSSN $_{\text {allowed }}$ travel into open areas with less physiological stress. Between 1500 to $1600 \mathrm{H}, \mathrm{T}_{\mathrm{SSN}}$ averaged mid-40's ${ }^{\circ} \mathrm{C}$ and $G$. wislizeni were observed spending considerable time in open areas. The data seem to indicate morning and afternoon ${ }^{\mathrm{T}}$ SSN ranging in the mid-40's ${ }^{\circ} \mathrm{C}$ as equally influential in affecting activity. Perhaps this temperature level represents the upper limit of thermal tolerance for the species. Activity, gradually declined between 1600 and $1700 \mathrm{H}$, even though environmental temperatures were usually favorable for activity. Mean hourly $\mathrm{T}_{\mathrm{ASH}}$ and $\mathrm{T}_{\mathrm{SSH}}$ were 31.3 and 
$31.8^{\circ} \mathrm{C}$, respectively. A mean $\mathrm{T}_{\mathrm{SSN}}$ was still unattainable because several values recorded in the hour ranged above the upper limit of the telethermometer. However, most $\mathrm{T}_{\text {SSN }}$ values were in the lower $40^{\prime} \mathrm{s}{ }^{\circ} \mathrm{C}$. Regal (1967), noting that many iguanids take shelter before the natural environment becomes unfavorable, postulated, "They must possess a mechanism insuring reversal of high temperature orientation following appropriate stimuli (exogenous or enoogenous), so they don't direct themselves toward maintenance of warm body temperature when the environment is cooling and becoming suboptimal for behavioral thermoreculation." Perhaps this explains why various individual G. wislizeni, faced with cool conditions retreated throughout the afternoon. At any rate, mean $\mathrm{T}_{B}$ for 1600 to $1700 \mathrm{H}$, exceeding the hourly mean value commencing at 0900 , was well within the species activity range.

The lowest $\mathrm{T}_{\mathrm{B}}$ voluntarily tolerated by G. wislizeni was $18.6^{\circ} \mathrm{C}$ and the highest temperature voluntarily tolerated was $43.4^{\circ} \mathrm{C}$. However, $96.8 \%$ of 283 body temperatures collected fell between 28 and $42^{\circ} \mathrm{C}$. (Figure 12). $\mathrm{T}_{\mathrm{B}}$ ranging within these limits probably correspond to the "normal activity range" of Cowles and Bogert (1944). G. wislizeni with $\mathrm{T}_{\mathrm{B}}$ values below $28^{\circ} \mathrm{C}$ were usually encountered in full sunlight, not far from the opening of the burrow or base of a shrub. The single $\mathrm{T}_{\mathrm{B}}$ value above $42^{\circ} \mathrm{C}$.was recorded at 1302 from an individual that had just traveled over a 


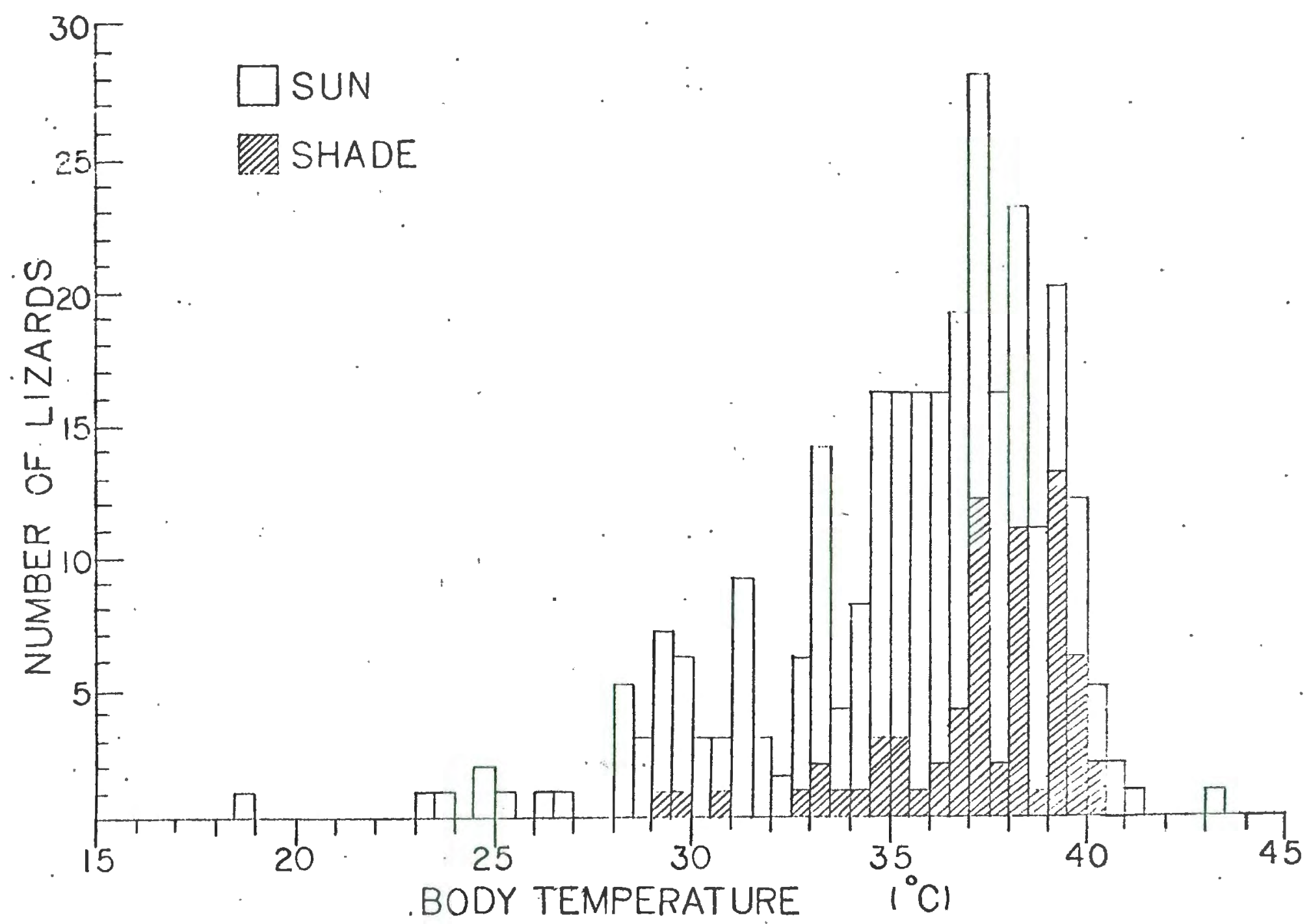

Figure 12. Frequency distribution of 283 body temperatures of active Gambelia wiazizeni.

w 
sand surface well above $50^{\circ} \mathrm{C}$. $T_{B}$ collected during the interval 0600 to $1800 \mathrm{H}$ produced a mean value very near $35.3^{\circ} \mathrm{C}(\overline{\mathrm{x}}=35.28$, S.D. $=3.8240)$.

The relation of environmental temperature with body temperature was also investigated in a thermal gradient chamber. Air temperatures at one end were $30.3^{\circ} \mathrm{C}$ and at the other $42.5^{\circ} \mathrm{C}$. Sand surface temperatures which were 25.8 at one end and $51.0+$ at the other, offered a much wider thermal gradient than did air. With the lights on air temperature near the infrared ( $\mathrm{T}_{\mathrm{AIR}}$ ) increased rapidly, and always exceeded $\mathrm{T}_{B}$ during the course of experimentation. Air temperature at end opposite infrared $\left(\mathrm{T}_{\mathrm{AOE}}\right)$, recorded in dim light and at the end opposite the IR lamp, increased gradually. $\mathrm{T}_{\mathrm{B}}$ was greater than $\mathrm{T}_{\mathrm{AOE}}$ 95.3\% of the time. Sand temperature near infrared (TSIR) increased at the greatest rate of all, and after 15 minutes exceeded the upper limit of the telethermometer $\left(51.0^{\circ} \mathrm{C}\right)$. T $\mathrm{B}$ recordings were never hịger than $\mathrm{T}_{S I R}$. Sand temperature at midchamber $\left(\mathrm{T}_{\mathrm{SMC}}\right)$ increase was slightly slower than $\mathrm{T}_{\mathrm{B}}$ and ranged close to $\mathrm{T}_{B}$ after an hour. $\mathrm{T}_{B}$ exceeded $\mathrm{T}_{S M C} 78.2 \%$ of the time. Sand temperature at end opposite infrared ( $\mathrm{T}_{\mathrm{SOE}}$ ) increased at a very slow rate and was rarely as high as $\mathrm{T}_{\mathrm{B}}(0.6 \%)$.

Prior to turning on incandescent and infrared lights the following $\mathrm{T}_{\mathrm{B}}$ and environmental temperature ranges were recorded: $\mathrm{T}_{\mathrm{B}}\left(21.3\right.$ to $\left.25.1^{\circ} \mathrm{C}\right)$; $\mathrm{T}_{\mathrm{AIR}}\left(21.7\right.$ to $\left.22.2^{\circ} \mathrm{C}\right)$; 
$\mathrm{T}_{\mathrm{AOE}}\left(21.6\right.$ to $\left.22.8^{\circ} \mathrm{C}\right) ; \mathrm{T}_{\mathrm{SIR}}\left(20.5\right.$ to $\left.22.5^{\circ} \mathrm{C}\right) ; \mathrm{T}_{\mathrm{SMC}}(21.5$ to $22.7^{\circ} \mathrm{C}$ ); and $\mathrm{T}_{\mathrm{SOE}}\left(20.7\right.$ to $\left.22.1^{\circ} \mathrm{C}\right)$. Activity at this time was minimal. Usually both individuals were resting under rocks, but occasionally one or both were found sitting in open portions of the chamber. After the lights were on 15 minutes, several of the environmental temperatures changed as follows: TAIR $\left(37.2\right.$ to $\left.40.8^{\circ} \mathrm{C}\right)$; TAOE $\left(25.4\right.$ to $\left.28.7^{\circ} \mathrm{C}\right) ; \mathrm{T}_{\mathrm{SIR}}\left(42.3\right.$ to $\left.47.8^{\circ} \mathrm{C}\right)$; and $\mathrm{T}_{\mathrm{SMC}}(28.2$ to $30.4^{\circ} \mathrm{C}$ ). TSOE changed little during the period (22.4$\left.23.9^{\circ} \mathrm{C}\right)$.

In the October experiment the lizards quickly took advantage of rapidly warming conditions. Basking under or very near the IR and incandescent lights, within 15 minutes $\mathrm{T}_{\mathrm{B}}$ ranged between 29.5 and $39.4^{\circ} \mathrm{C}$. Combining all measurements, mean $\mathrm{T}_{\mathrm{B}}$ values prior to and 15 minutes after turning on the lights were 23.8 and $36.4^{\circ} \mathrm{C}$, respectively. A significant difference of $12.6^{\circ} \mathrm{C}(t=8.9079, P<0.01)$. In the December experiment lizards were slower to emerge, and when doing so, often remained in the dimly lit end opposite the IR lamp. However, when the lizards were basking, $\mathrm{T}_{\mathrm{B}}$ changes were similar to those in October. After 15 minutes, $\mathrm{T}_{\mathrm{B}}$ ranged from 25.4 to $39.5^{\circ} \mathrm{C}$. Combining all measurements, mean $\mathrm{T}_{\mathrm{B}}$ values prior to and 15 after turning on the lights were 23.3 and $30.2^{\circ} \mathrm{C}$, respectively, a significant difference of $6.9^{\circ} \mathrm{C}(t=2.8470, P<0.02)$.

During each observation environmental temperatures 
continued to increase until the IR light was turned off. However, after the first hour changes were gradual. Occasionally no change or a slight drop in temperature occurred. Hourly fluctuations were usually less than $\pm 1^{\circ} \mathrm{C}$. The environmental temperatures of October and December demonstrated similar ranges and were combined. Means for each component were: $\mathrm{T}_{\mathrm{AIR}}\left(42.5^{\circ} \mathrm{C}\right), \mathrm{T}_{\mathrm{AOE}}\left(30.3^{\circ} \mathrm{C}\right), \mathrm{T}_{\mathrm{SMC}}$ $\left(32.9^{\circ} \mathrm{C}\right)$ and $\mathrm{T}_{\mathrm{SOE}}\left(25.8^{\circ} \mathrm{C}\right)$. Because of instrument limitations, a mean TSIR could not be determined.

During October observations both lizards 'were quite active after basking, moving from one end of the chamber to the other. However, after the initial 15 minute warming period, time spent at the IR end was brief and the lizards seemed under stress (i.e., panting) when moving through this area. After about an hour both lizards spent most of the time occupying the middle one-third of the chamber. At this time activity was variable. Usually short periods of considerable exploratory movement were intermixed with lengtiny periods of quiescence. Toward the end of each observation period, one or both individuals often spent most of the time in dimly lit portions of the chamber. Throughout each observation period a lizard never retreated under rocks for longer than a few minutes. Though activity during each 4 hour period was diverse, from 15 minutes on $\mathrm{T}_{B}$ did not vary significantly $(t=0.8737, \mathrm{P}>.10)$. The situation encountered in December observations 
was a little different. After the lights were turned on, either or both lizards failed to immediately emerge to bask. often an individual remained under a rock for longer than the first hour. Frequently a lizard would bask then retreat under a rock for several minutes. Over the 4 hours most of the activity involved repeated emergence and retreat. A lizard not retreating after basking usually undertook the exploratory movements I observed in October. At all times activity was less than in October, but during the final 2 hours the extent of movement was greatest, and sometimes resembled that during the earlier month. Environmental temperatures varied little from those recorded in October. However, the December mean $\mathrm{T}_{\mathrm{B}}$ recorded at 1 hour was significantly higher than the mean $\mathrm{T}_{\mathrm{B}}$ recorded at 15 minutes $(t=$ $2.8470, P<0.02)$. Likewise, mean $\mathrm{T}_{\mathrm{B}}$ recorded at 4 hours was significantly higher than the mean $T_{B}$ recorded at 1 hour $(t=2.3149, P<0.05)$. At all time intervals mean $T B$ for October were significantly higher than mean $T_{B}$ for December except at 4 hours $(t=0.3994, P>0.10)$, when mean values were 37.3 and $36.3^{\circ} \mathrm{C}$, respectively.

In December, the reluctance of G. wislizeni to emerge, and remain active once emerged, may indicate some sort of prehibernatory behavior. Perhaps selection of cooler portions of the chamber (retreats) reflects normal fall behavior. McGinnis (1966) explains, "Selection of lower temperatures in liall animals may possibly be of ligh adaptive significance. A lizard which seeks out a cool 
retreat in mid or late fall may not experience ambient temperatures high enough to elicit emergence until favorable spring conditions are present." Chamber temperatures were comparable to mid summer conditions. When not provided areas for escape, lizards frequently attained higher $T_{B}$. However, the drive to retreat was never completely extinguished. This suggests that in addition to temperature, other stimuli, probably including photoperiod, are necessary to overcome the prehibernatory behavior. Such a strongly regulated internal mechanism may inhibit premature emergence due to a solitary warm day.

Combining October and December data, a total of 170 body and environmental temperatures were recorded under experimental conditions. October $\mathrm{T}_{\mathrm{B}}$ were 29.5 to $40.9^{\circ} \mathrm{C}$; December $\mathrm{T}_{\mathrm{B}}$ were 25.4 to $40.5^{\circ} \mathrm{C}$. $94.1 \%$ of the temperatures fell inthe range of 29.0 to $41.0^{\circ} \mathrm{C}$ (Figure 13). This range corresponds nicely with the proposed "normal activity range" for field data. All temperatures outside this group, recorded in December, were 25.0 to $28.0^{\circ} \mathrm{C}$. In every case, these values were secured prior to first emergence.

Multiple regression analysis of certain components measured in the field shows that environmental temperatures have considerable effect on body temperature (Table III). Consideration of the effect of each component separately on $T_{B}$ (correlation of $X$ and $Y$ ). reveals $T_{A S H}$ and $T_{S S N}$ to be 


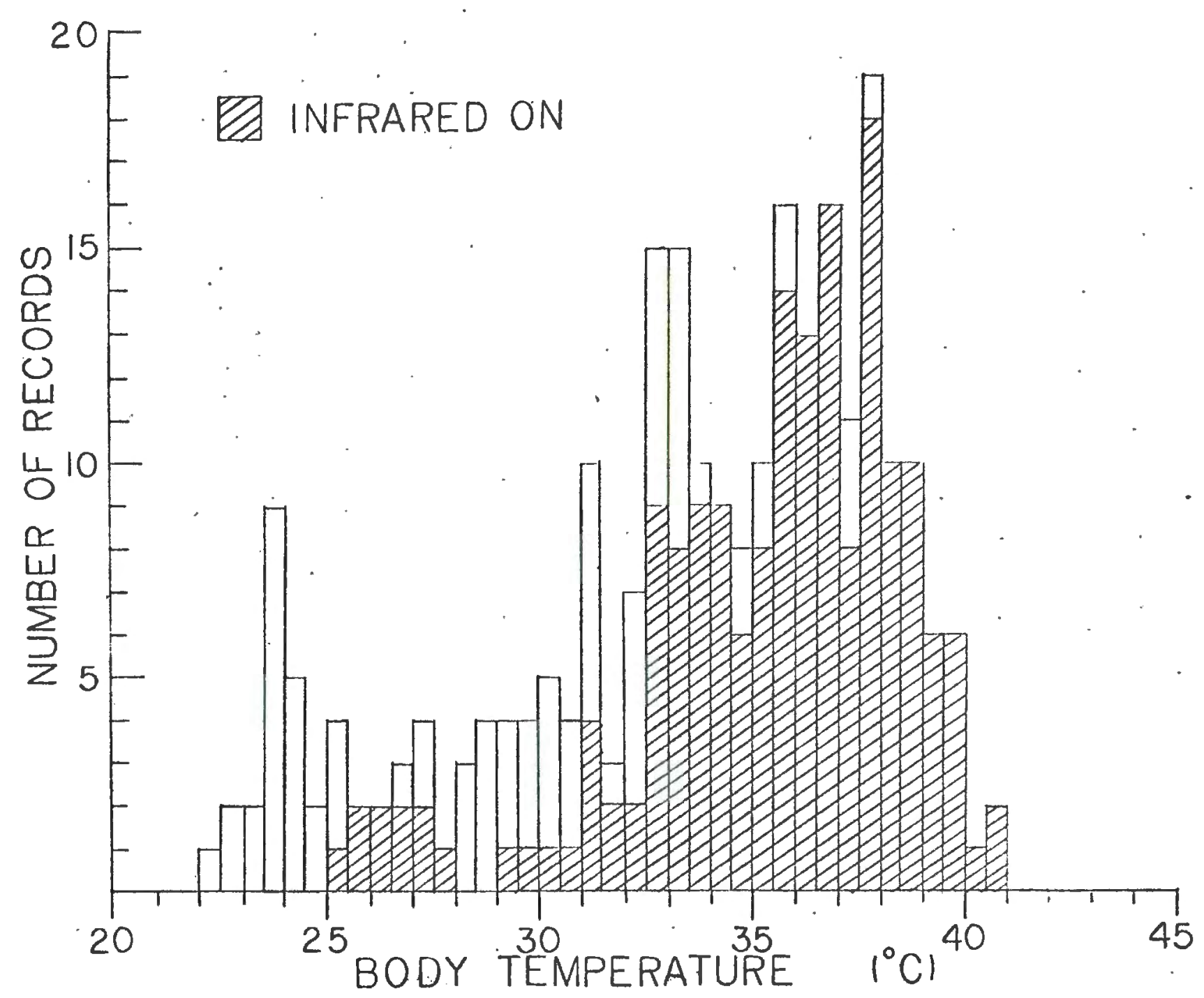

Figure 13. Frequency distribution of 256 body temperatures of Gambelia :ielizeni recorded in a thermal gradient chamber. 170 body temperatures sere secured when the infrared light was on. 
TABLE III. MULTIPLE REgRESSION - COMPONENTS EFFECTING TB

\begin{tabular}{l|c|l|c|c|c|c}
\hline \hline & MEAN & $\begin{array}{l}\text { STANDARD } \\
\text { DEVIATION }\end{array}$ & $\begin{array}{c}\text { CORRELATION } \\
\text { X VS Y }\end{array}$ & $\begin{array}{c}\text { REGRESION } \\
\text { COEFFICIENT }\end{array}$ & $\begin{array}{l}\text { STD. ERROR } \\
\text { OF REG. COEF. }\end{array}$ & $\begin{array}{l}\text { COMPUTED } \\
\text { T VALUE }\end{array}$ \\
\hline TASH & 29.7166 & 2.8330 & $0.5753^{*}$ & 0.6486 & 0.3625 & 1.7892 \\
TSSN $_{\text {SSN }}$ & 42.0800 & 5.1193 & $0.5859^{*}$ & 0.4382 & 0.2127 & $2.0604^{*}$ \\
TSSH $_{\text {SSH }}$ & 26.9400 & 2.6231 & -0.2586 & -1.7986 & 0.5177 & $-3.4743^{*}$ \\
SVL & 89.8333 & 8.7023 & -0.2201 & 0.1835 & 0.2406 & 0.7627 \\
WT & 20.6567 & 6.8999 & -0.2272 & -0.0324 & 0.2634 & -0.1232 \\
SEX & 1.4667 & 0.5074 & -0.1371 & -5.8312 & 15.7671 & -0.3698 \\
TIME & 1.1185 & 3.2814 & -0.2653 & 11.8637 & 4.1854 & $2.8346^{*}$ \\
TB & 35.7801 & 3.8240 & & - & - & - \\
\hline
\end{tabular}

INTERCEPT 18.2977

MULTIPLE CORRELATION 0.7753

STD. ERROR OF ESTIMATE 2.7728

\footnotetext{
* Indicates significant at 95 confidence level.
} 
most significant. Evaluation in this manner shows the contribution of $\mathrm{T}_{\mathrm{SSH}}$ to be insignificant. Adjusting for the effect of all other components (computed-T value), $\mathrm{T}_{S S N}$ and $\mathrm{T}_{\mathrm{SSH}}$ proved to be highly significant. $\mathrm{T}_{\mathrm{ASH}}$ only approached marginal significance. This latter way of evaluating the effect of components on $T_{B}$ conveniently coincides with some of the previous interpretation of field observations:

1) though all environmental temperatures imparted some influence on $\mathrm{T}_{\mathrm{B}}$, the substrate temperatures appeared most important; 2) the fact that $\mathrm{T}_{\mathrm{SSH}}$ showed negative correlation suggests thermoregulatory responses by G. wislizeni. Assessment of the multiple correlation value (.77532) indicates $40 \%$ of the effect on $\mathrm{T}_{\mathrm{B}}$ unaccounted for. A large portion of this value probably involves the lizard's direct contact with solar radiation.

From data collected from the thermal gradient chamber, multiple regression analysis of the effect of environmental temperatures on body temperature confirms the importance of substrate temperatures. Results for the adult female $G$. wislizeni are found in Table IV. TSMC shows a highly significant effect on $T_{B}$ for both correlation of $X$ vs $Y$ and computed $\mathrm{T}$ value relationships. Both lizards were observed to spend considerable time in the vicinity of the TSMC thermister lead. Similar mean temperature levels for $\mathrm{T}_{\mathrm{SMC}}$ and $T_{B}$ perhaps is indicative of location selectivity. Unfortunately, TSIR could not be evaluated. Interpretation of 
TABLE iV. MULTIPLE REGRESSION-THERMAL GRADIENT TEN EFFECTING TB

\begin{tabular}{l|l|c|c|c|c|c}
\hline \hline & MEAN & $\begin{array}{c}\text { STANDARD } \\
\text { DEVIATION }\end{array}$ & $\begin{array}{c}\text { CORRELATION } \\
\text { XVS Y }\end{array}$ & $\begin{array}{l}\text { REGRESSION } \\
\text { COEFFICIENT }\end{array}$ & $\begin{array}{l}\text { STD. ERROR } \\
\text { OF REG. COEF. }\end{array}$ & $\begin{array}{l}\text { COMPUTED } \\
\text { T VALUE }\end{array}$ \\
\hline TAIR & 42.4917 & 3.5480 & 0.4212 & 0.1031 & 0.1896 & 0.5440 \\
$T_{A O E}$ & 30.3293 & 2.0490 & 0.4215 & -0.0784 & 0.4913 & -0.1595 \\
$T_{S M C}$ & 32.9564 & 3.2433 & 0.5013 & 0.5706 & 0.1930 & 2.9557 \\
$T_{S O E}$ & 25.8129 & 2.1161 & 0.2543 & -0.2481 & 0.2688 & -0.9299 \\
$T_{B}$ & 35.5281 & 3.2143 & - & - & - & - \\
\hline
\end{tabular}

INTERCEPT 21.1241

MULTIPLE CORRELATION " 0.5234

STD. ERROR OF ESTIMATE ： $\quad 2.8065$ 
the multiple correlation value $(0.5234)$ shows only $27 \%$ of the effect on $\mathrm{T}_{\mathrm{B}}$ accounted for. Light from infrared and incandescent lamps probably contributed most of the remaining effect.

Multiple regression analysis was employed to investigate the effect of lag environmental temperatures on body temperature. Data recorded at timed intervals were used and each $\mathrm{T}_{\mathrm{B}}$ was compared with the set of environmental temperatures from the previous 30 minute interval. Results for the adult female are shown in Table V. Neither correlation of $X$ vs $Y$ or computed- $T$ values show any significant relationships. Multiple correlation value $(0.26063)$ shows $.07 \%$ of the effect on $\mathrm{T}_{\mathrm{B}}$ accounted for. Apparently $\mathrm{T}_{\mathrm{B}}$ is not affected by environmental temperatures of several minutes earlier. Various portions of field and laboratory data seem to indicate environmental temperatures to which G. wislizeni are immediately exposed have greatest effect on $\mathrm{T}_{\mathrm{B}}$. The rate at which $\mathrm{T}_{\mathrm{B}}$ increases in the first 15 minutes of observation in a thermal gradient was mentioned above. More evidence suggesting the importance of the effect of present environmental temperatures on $\mathrm{T}_{\mathrm{B}}$ is available in the results from the experiment dealing with heat stress (to be discussed later). Lizards tethered in the sun showed $\mathrm{T}_{\mathrm{B}}$ increased as great as $10^{\circ} \mathrm{C}$ in just $2 \mathrm{~min}$. and 35 sec. 
TABLE Vo MULTIPLE REGRESSIONooousTHERMAL GRADIENT, LAG PERIOD

\begin{tabular}{|c|c|c|c|c|c|c|}
\hline & MEAN & $\begin{array}{l}\text { STANDARD } \\
\text { DEVIATION }\end{array}$ & $\begin{array}{l}\text { CURRELATIUN } \\
X \vee S Y Y\end{array}$ & $\begin{array}{l}\text { RELREDSIUN } \\
\text { COEFFILIENT }\end{array}$ & $\begin{array}{l}\text { STDO ERR.JK } \\
\text { vF KEG, COEF, }\end{array}$ & $\begin{array}{l}\text { SUMPUTED } \\
\text { T VALUE }\end{array}$ \\
\hline$T_{A I R}$ & 42.4917 & 3.5480 & 0.2069 & 0.3647 & 0.2165 & 1.6846 \\
\hline$T_{A O E}$ & 30.3293 & 2.0490 & 0.0954 & -0.1945 & 0.5598 & $-0,3475$ \\
\hline$T_{S M C}$ & 32.9564 & 3.2433 & 0.0617 & -0.0838 & 0.2199 & -0.3807 \\
\hline TSOE & 25.8129 & 201161 & -0.0292 & -0.0928 & 0.3052 & -0.3040 \\
\hline$T_{B}$ & 35.5281 & 3.2143 & - & - & - & - \\
\hline
\end{tabular}

\begin{tabular}{lr}
\hline INTERCEPT & 30.9271 \\
MULTIPLE CORRELATION & 0.2606 \\
STD。 ERROR OF ESTIMATE & 301972
\end{tabular}


Relation of Size and Sex to Body Temperature

Variation in body temperature could possibly arise from ontogenetic or sexual differences in preferred temperatures or heating rates. This may be reflected by changes in proportional representation of different sexes or sizes of individuals with changes in time of day or immediate weather conditions (Heatwole, 1970). The results reported here on the relationship of size and sex with $\mathrm{T}_{\mathrm{B}}$, are based entirely on field data. Snout-vent length ( $\mathrm{mm}$ ) and weight $(g)$ were used in the investigation of the relationship of size with $\mathrm{T}_{\mathrm{B}}$.

For the population, hourly mean snout-vent length of active $G$. wislizeni increased gradually in the morning, but after $1100 \mathrm{H}$ remained constant (Table VI). No hour period showed a significant difference from those of any other one except that SVL's at 0800 were significantly lower than those from $1600(t=2.1030, P<0.05)$. The 0700 value is based only on 5 measurements and consequently may not be a reliable sample.

Temporal changes in mean snout-vent lengths were slight in. G. wislizeni and basically indicate that individuals of smallest SVL emerge earlier than others. However, the situation warrants exceptions; lizards up to $102 \mathrm{~mm}$ were active prior to $0900 \mathrm{H}$. Even if changes in mean hourly SVL had been considerable, it is doubtful this would have had any effect on the distribution of mean body temperatures. 
TABLE VI. MEAN HOURLY SNOUT - VENT LENGHT AND WEIGHT FOR A POPULATION OF Gambelia Wislizeni

\begin{tabular}{l|c|c|c}
\hline \hline HOURS & $\bar{x}$ SVL $(\mathrm{mm})$ & $\bar{x}$ WEIGHT $(\mathrm{g})$ & $\begin{array}{c}\text { NUMBER OF } \\
\text { INDIVIDUALS }\end{array}$ \\
\hline 0700 & 86.4 & 14.9 & 5 \\
0800 & 82.8 & 19.9 & 16 \\
0900 & 89.7 & 20.5 & 29 \\
1000 & 88.1 & 23.1 & 23 \\
1100 & 91.2 & 22.8 & 27 \\
1200 & 91.4 & 28.2 & 26 \\
1300 & 90.1 & 21.1 & 20 \\
1400 & 90.0 & 22.5 & 20 \\
1500 & 89.1 & 20.5 & 27 \\
1600 & 92.1 & 23.2 & 10 \\
\hline
\end{tabular}


Multiple regression analysis of 203 SVL measurements (Table III), ranging from 45.0 to $114.0 \mathrm{~mm}$, show this aspect of size to be insignificant (correlation of $X$ vs $Y$ and computed-T value) in affecting $\mathrm{T}_{\mathrm{B}}$. These results agree with findings for other lizard species (Bogert, 1949; Mayhew, 1963; and lloatwole, 1970).

For the population hourly mean weights of active $G$. wislizeni increased between 07:00 and 10:00 and between 1100 and 1200. Mean body weight declined considerably from the hour 1200 to the hour 1300. During the later hours of activity mean weights remained constant (Table VI). Mean hourly weight for 0700 was significantly lower than all hourly periods except 0900, 1200, and 1500. Mean hourly weight for 1200 was significantly higher than all hours except 1000,1100 , and 1600 (t-test).

Temporal changes in weight were greater and more variable than changes in SVL. Nonetheless, multiple regression analysis of 203 weight measurements, ranging from 2.5 to $49.7 \mathrm{~g}$, show this aspect of size to be insignificant (correlation of $X$ vs $Y$ and computed $T$ value) in affecting $\mathrm{T}_{\mathrm{B}}$. Bogert (1949) and Heatwole (1970) reported weight to be insignificantly correlated with $\mathrm{T}_{B}$ in several species of lizards.

Hourly variability in the number of active individuals for each sex was distinctly different. During the morning, females were proportionally the most abundant sex, 
comprising 46.9 to $63.9 \%$ of the total number captured. The lower value was obtained between 1000 and $1100 \mathrm{H}$. Males, though numerous throughout the day, did not become profoundly the most abundant sex until afternoon. For hourly periods 1200 through 1600, males comprised 60 to $71.4 \%$ of the total number captured. The reason for decline in number of females in the afternoon is not clear. Perhaps, confronted with afternoon low humidity and high environmental temperatures, a depleted fat supply makes adult females more susceptible to dessication. They may retreat to minimize water loss and thus avoid physiological impairmont.

Mean body temperature for males and females, recorded between 0600 and $1800 \mathrm{H}$, were 35.3 and $35.1^{\circ} \mathrm{C}$, respectively. Male $T_{B}$ ranged from 26.3 to $40.8^{\circ} \mathrm{C}$; female $T_{B}$ ranged from 18.6 to $43.4^{\circ} \mathrm{C}$. Differing hourly abundance and $T_{B}$ range between sexes might indicate selection of different $T_{B}$ preference. However, multiple regression analysis shows sex to be insignificant (correlation of $X$ vs $Y$ and computed $T$ value) in affecting $T_{B}$. Therefore sexual dimorphism in $T_{B}$ seems unlikely. When sexual dimorphism in $\mathrm{T}_{B}$ does occur (females with higher values) it is frequently related to viviparity (Steward, 1965); G. wislizeni is oviparous.

Relation of Time of Day to Body Temperature

Ruibal (1961) found a significant difference between morning mean and range and afternoon mean and range of $T_{B}$ 
of anoles. Mean hourly $\mathrm{T}_{\mathrm{B}}$ of $G$. wistizeni during periods beginning at 1300 and 1600 were significantly higher than for all morning hourly periods ( $t$-test). Hourly mean body temperatures are listed in Table VII. The 0600 value is based only on 2 measurements and consequently is not a reliable sample.

Multiple regression analysis indicates time is highly significant (computed $\mathrm{T}$ value) in affecting body temperature. Afternoon $\mathrm{T}_{\mathrm{B}}$ hourly means and ranges were higher than morning values. However, differences between hourly mean $T_{B}$ were significant in only some of the comparisons. Maximum morning and afternoon $\mathrm{T}_{\mathrm{B}}$ ranges did not differ greatly; considerable variance in minimum range probably reflects cooler morning environmental temperatures. With this in mind, one must differentiate between the effect of time in a direct sense and an indirect sense. If time is directly effective, than some physiological adaptation must bo prosent which with the proper cnvironnental cues, elicits a shift in $\mathrm{T}_{\mathrm{B}}$ levels. Time as an indirect effect on $\mathrm{T}_{B}$ results from the status of environmental temperature conditions. The fact that some G. wislizeni attained maximum $T_{B}$ range as early as $0800-0900 \mathrm{H}$, and that after this time the maximum range remained fairly constant, seems to indicate that the effect of time is indirect. Later in the day, warming environmental temperatures were responsible for a rise in minimum $T_{B}$ range. Elevation of 


\begin{tabular}{l|c|c}
$\begin{array}{c}\text { TABLE VII. } \\
\text { MEAN HOURLY } \\
\text { Gambelia }\end{array}$ & $\begin{array}{c}T_{B} \text { FOR A } \\
\text { Wislizeni }\end{array}$ & \multicolumn{1}{c}{ POPULATION OF } \\
\hline HOUR & $T_{B}\left({ }^{\circ} \mathrm{C}\right)$ & $\begin{array}{c}\text { NUMBER OF } \\
\text { INDIVIDUALS }\end{array}$ \\
\hline 0600 & 32.3 & 2 \\
0700 & 34.4 & 21 \\
0800 & 34.7 & 35 \\
0900 & 35.2 & 52 \\
1000 & 34.9 & 32 \\
1100 & 35.2 & 27 \\
1200 & 34.9 & 23 \\
1300 & 37.2 & 21 \\
1400 & 35.9 & 25 \\
1500 & 36.1 & 33 \\
1600 & 36.5 & 12 \\
\hline
\end{tabular}


minimum $T_{B}$ range is largely responsible for increased afternoon mean hourly $T_{B}$ (Figure 14). It would appear $G$. wislizeni pursues a certain $\mathrm{T}_{\mathrm{B}}$ level for the entire day, but success in achieving this level is greatly limited by inability of the species to compensate equally well for varying environmental temperatures.

Methods of Thermoregulation

Hourly changes in body temperature will have greater meaning if the ways in which a species thermoregulates are examined. The thermoregulatory methods employed by $G$. wislizeni vary with prevailing thermal conditions. Atsatt (1939) speculated that color change in iguanids in response to temperature had a thermoregulatory function. Porter (1968) described G. wislizeni as possessing pronounced color change ability. At the time of morning emergence, lizards were dark in color. At low body temperature (below normal activity range) extensive gray suffusion occurred on gular area, the inner aspect of all limbs, ventral trunk (especially along lateral edges of chest and abdomen), and along the entire ventral surface of the tail. Dorsal ground color and blotches were extremely dark brown to almost black. With rising $\mathrm{T}_{B}$ (above lower limit of normal activity range), coloration became lighter and during warmest portions of the day blanching predominated. Norris (1967) showed that temperature dependent color change affects the reflectance of the integument and hence the rate 


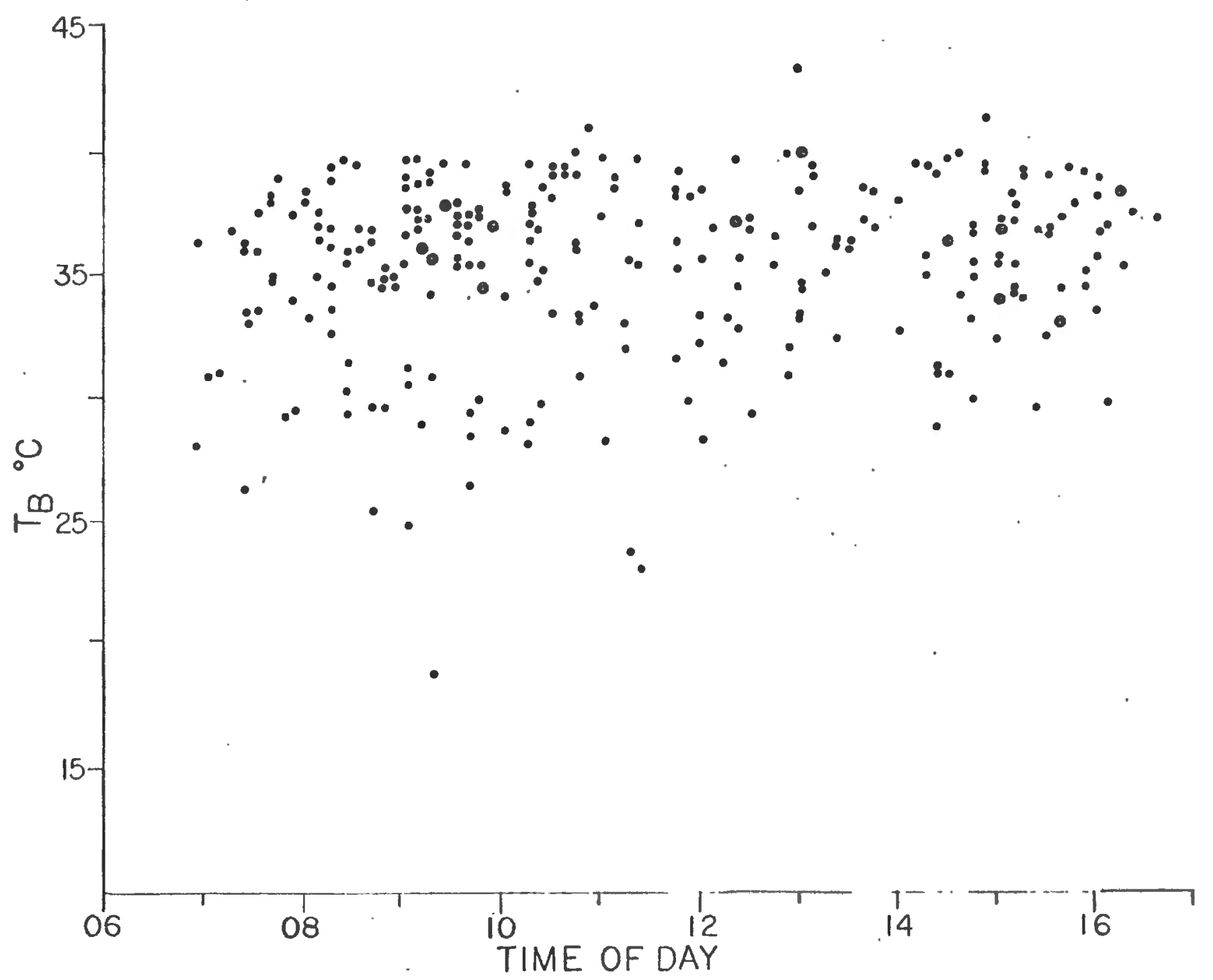

Figure 14. Relationship of body temperature $\left(T_{B}\right)$ of $G$. wislizeni to time of day. 
at which radiant energy is absorbed. Observation of $G$. wislizeni in a thermal gradient showed color change to be rapid. When going from one extreme to the other in a few minutes, color change was always accompanied by a marked increase in $\mathrm{T}_{B}$. For these cases, color change undoubtedly plays an integral part in thermoregulation.

Various behavioral acts contribute greatly to temperature regulation. Emerging G. wislizeni immediately began basking, an activity pattern discussed at great length for other species (Bogert, 1959; Heath, 1962 and 1965; Heatwole, 1970; Judd, 1975). Basking involved assumption of position and postures which allowed for maximum heat uptake. Usually, lizards were oriented so that their backs were at right angles to the sun's rays. Since the sun was low in the sky during early morning, G. wislizeni were often oriented almost vertically. This was accomplished in a variety of ways - sitting with forelimbs straight and back remarkably swayed, resting on sunward side of ground surface irregularities, placing forelimbs on some elevated object such as a branch, and climbing onto incline surface of rocks. Basking lizards remained perfectly still and often closed their eyes. Heath (1965) and Dewitt (1967) report that eye closure in other species serves as a mechanism to equalize head and body temperature. The dark pigmentation of the dorsum at this time may facilitate heat gain and the gray suffusion may absorb reflected heat 
(Judd, 1975). Depending on weather conditions the length of time spent basking was variable. Under warm conditions basking ceased around $0900 \mathrm{H}$, but when weather was cool activity was sometimes interrupted by intermittent basking at any time during the day.

Basking or heliothermic behavior, deriving heat needed to energize body chemistry directly from the sun, is best appreciated when populations at altitudinal or latitudinal extremes are studied (Pearson, 1954; and Mueller, 1969). It was already indicated that G. wislizeni in Harney County are near the northern limit of their range. In this region cool weather conditions often persist well into the summer. Nonetheless, for the most part, activity continued uninterrupted. As an indication of heliothermic ability the difference between mean $\mathrm{T}_{\mathrm{B}}$ and $\mathrm{T}_{\mathrm{ASH}}$ for 20 measurements taken on cool mornings in June 1975 was $14.7^{\circ} \mathrm{C}$. One individual possessed a $\mathrm{T}_{\mathrm{B}}$ of $31.4^{\circ} \mathrm{C}$ when $\mathrm{T}_{\mathrm{ASH}}$ was $13.8^{\circ} \mathrm{C}$, a difference of $17.6^{\circ} \mathrm{C}$.

Basking usually ceased when G. wislizeni began to move about. The "alerting movements" described for another species by Heatwole (1970) were frequent in G. wislizeni and preceeded any actual travel. Once a lizard attained $\mathrm{T}_{\mathrm{B}}$ within the normal activity range $\left(28.0-42.0^{\circ} \mathrm{C}\right)$ the re was little need to orient with the back at right angles to the sun; as morning progressed, lizards shifted to other positions and postures in an effort to maintain $\mathrm{T}_{B}$ within the 
nomal activity range. Many adopted a variety of positions at more oblinge angles to the sun's rays, which probably roduced the amount of energy absorbed per unit of surface area (Bartlett and Gates, 1967; Porter and Gates, 1969).

By $1000 \mathrm{H}$ it was quite difficult for an active lizard to attain a position and posture that would greatly reduce body surface area exposed to the sun's rays. Lizards in the open, when pausing between movements, would sometimes position themselves so as to be facing the sun. In this manner the body axis was parallel with the sun's rays. Posture involved straightening the forelimbs and swaying the back so as to have most of the light striking the white throat and chest. Lizards assuming this stance would not only be shielded by their posture, but their heat gain would probably be minimized by the greater reflectance of the white exposed underside (Fieatwole, 1970). Hutchinson and Larimer (1960), Hirth (1963), Norris and Lowe (1964), Norris (1967), and Porter (1968) have shown that in a number of lizard species the venter reflects a greater amount of radiant energy than does the dorsum. Therefore a combination of reducing the angle formed between the body and the sun's rays and facing toward rather than away from the sun is probably a means of temporarily reducing heat gain which would tend to retard increase in $T_{B}$. On warm days $G$. wistizeni might adopt this position and posture any time roughly after 0900. However, greatest frequency occurred during the time 
span 1000 to 1400 when solar radiation was most intense. Almost every lizard encountered pausing in the open between 1300 and $1400 \mathrm{H}$ was observed facing the sun with body axis parallel to the sun's rays.

While active, G. wislizeni frequently changed location (Figure 15). With rising environmental temperatures less time was spent in direct sunlight. After $1000 \mathrm{H} \mathrm{lizards}$ usually shuttled between sun and shade. At moderate environ-. mental temperatures they chose broken shade, but when conditions became quite warm they moved to full shade. Frequent-, 1y, lizards sighted in broken shade or direct sunlight would exhibit tail wagging. Perhaps this is an adaptation which serves to push aside the hot surface layer of sand, thus. exposing a cooler surface to the tail. As previously mentioned, TSSN usually exceeded $50^{\circ} \mathrm{C}$ before $1100 \mathrm{H}$ and remained above this level until mid to late afternoon. Consequently, movements into the open declined. In early afternoon most lizards remained in the shade. At this time individuals were relatively quiescent and seemed to rely largely on concealment for protection. Lizards venturing into open areas from 1000 to $1500 \mathrm{H}$ did so for very brief periods and proceeded at a trot, keeping body and tail well up off the sand. When pausing in the open, limbs were bent and extended out to the sides with toes pointed skyward; back arched and venter held well above sand, and tail held off sand in a variety of ways from pointed rearward and 




Figure 15. Based on 57 individual hourly observations, diel changes in location of Gambelia wislizeni. 
completely straight to slightly bent with tip pointed skyward. When maintaining such a posutre for more than a few seconds, lizards would alternate lifting forelimbs off the sand. Brattstrom (1971) believes there is a critical toe or tail temperature that elicits the adoption of this posutre. The posutre differs markedly from that assumed when TSSN was within tolerance ranges-i.e., lizards rested tail and hindquarters on the sand during pauses (Figure 16). On warm days early afternoon TSSH may reach $40^{\circ} \mathrm{C}$. In such instances temperatures over most of the sand surface were at or exceeded the upper limit of the activity range for G. wislizeni. Lizards no longer rested in the shade with venter flush with the sand; they stood on all fours. Many placed the anterior $1 / 2$ of their bodies over mats of grass, leaves or low limbs of shrubs. Some individuals climbed into vegetation and oriented vertically with their venters toward the sun. They would hold this position for as long as $30 \mathrm{~min}$ utes. This kind of behavior was observed throughout the afternoon. It would appear to be a last resort to escape high temperatures present on the sand. As high as a meter above the sand surface heat gain was probably retarded because of reduced conduction and absorption of reflected radiant energy. Position and orientation may also retard heat gain by increasing reflectance and decreasing the incident angle of the sun's rays (Judd, 1975).

After 1500, the intensity of solar radiation declined 


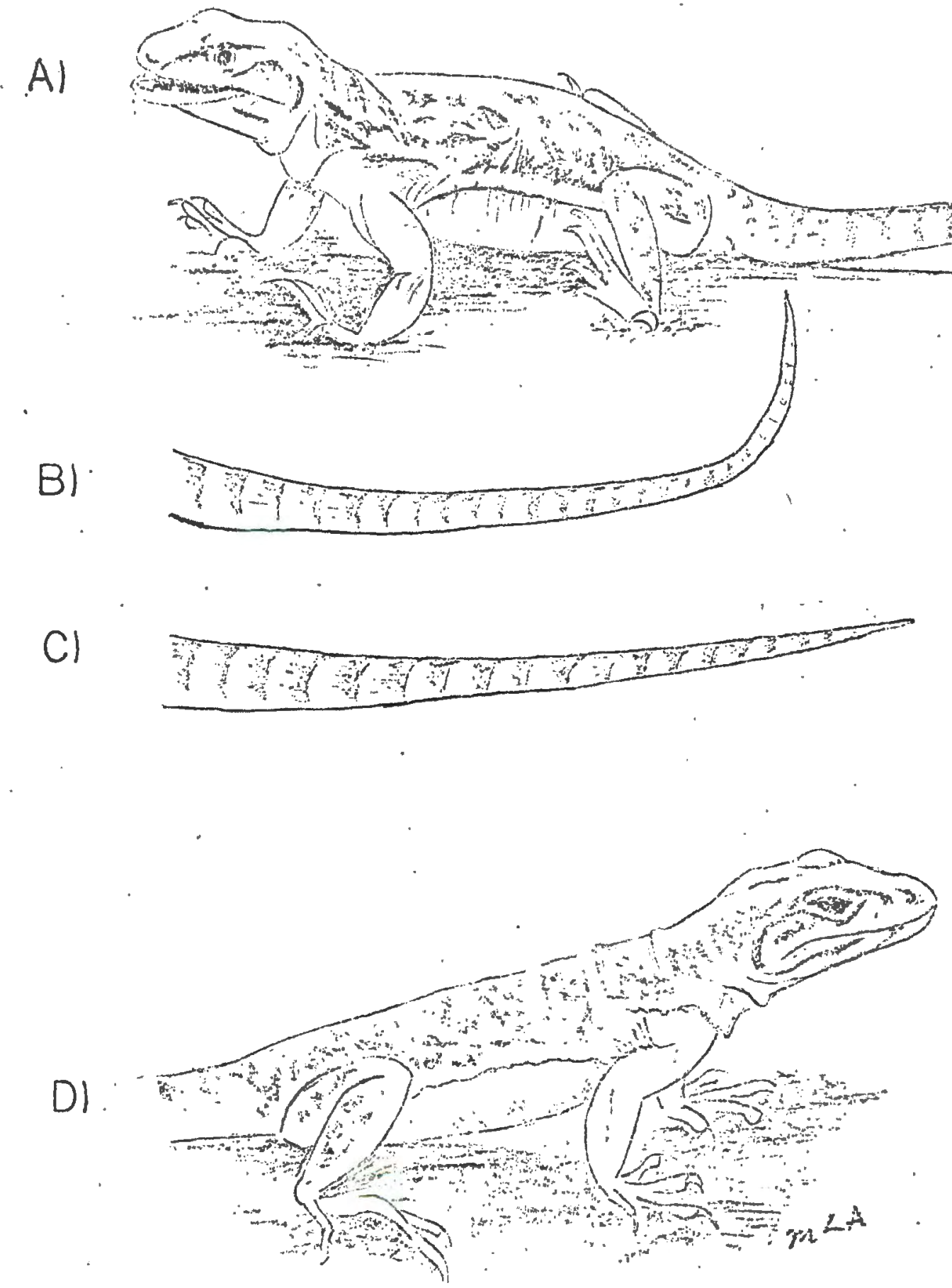

Figure 16. Thermoregulation posture. A) panting lizard in toes up position; B) Tail-up, pointing skyward; C) Tail-up, pointed posterioriy; D) Lizard in typical resting position. 
which allowed environmental temperatures, especially TSSN, to drop. Lizards encountered in the open positioned themselves, with respect to the sun's rays, at varying oblique angles. They either faced toward or away from the sun, the latter category increasing during the final hour of activity. However, the equivalent of morning basking position, i.e.; with the back at right angles to the sun, seldom occurred. Since $\mathrm{T}_{\mathrm{B}}$ levels were usually within the normal activity range, the afternoon pattern never required a recurrence of the morning one.

Thigmothermic behavior (deriving heat by conduction from the sand) is displinged by G. wislizeni more often than one might expect. Resting with venter completely flush on the sand or rock surface and demonstrating lateral expansion of the trunk, such behavior was used to supplement morning basking and to help maintain $\mathrm{TB}$ in the appropriate range throughout the day. However, it was most evident during days when weather produced marginal conditions for activity or late in the afternoon when the sun's rays were greatly diminished. A common practice of several species involved in thigmothermic behavior is to "wriggle" or make sinuous movments with the body to shift sand from side to side. Norris (1953) noted Dipsosaurus dorsalis performing such behavior, seemingly attempting to push away the hot upper layer of sand to get at the cooler lower layers. Hirth (1963) and Bogert (1959) observed Ameiva quadrilineata and Sceloporus unduzatus performing such behavior for the opposite reason - to remove the upper cool layer to get at 
the warmer lower layers. G. wislizeni demonstrated sinuous movement quite frequently, but always to get next to warmer conditions. For example, on 26 June 1975, during an unseasonally cool afternoon thick cumulous clouds covered most of the sky, allowing the sun's rays to reach the sand surface only for brief periods of time. Wind was gusty, from the south. Observed for approximately an hour, a lizard covered considerable ground, traveling 5 to 10 meterș on most moves. Each time the lizard came to a stop it would kick sand posteriorly with the hindlimbs and do a "belly flop" on the sa sand. Venter on the sand, the 'lizard would "wriggle" a cou couple of times then rest quietly for several minutes. Later, during the same day and on days of similar weather this belly flop behavior was observed in other individuals too.

Except during extremely cool condition, G. wislizeni were observed above ground every hour between 0600 and 1800 H. When environmental temperatures reached maximum levels fewer lizards were sighted, and almost always they were in shade. The fact that they were in shade and revealed less of themselves may contribute to the fact that few individuals were seen. However, at all hours of the afternoon lizards were obsẹved entering burrows and it is most likely this is the main reason for fewer sightings. At Frog Spring there were numerous rodent burrows, but $G$. wislizeni often constructed their own burrows. Cowles and Bogert (1944) noted the capability of the lizards to make their own sometimes extensive burrows. Accessibility of 
burrows served several purposes, but during periods when rising environmental temperatures were approaching maximum levels the primary purpose was probably the same as for those encountered in shade, to escape thermal stress. For the most part it appears self-constructed burrows were used in thermoregulation. They scrved as a refuge for escape from cool, as well as warm temperatures. G. wislizeni never chose self constructed burrows when attempting to escape our pursuit. At Frog Spring rodent burrows were in infrequently used for retreat of any nature except escape from a captor's pursuit. Elsewhere it appears they were used in thermoregulation.

Self-constructed burrows were usually located next to vegetation, the roots providing foundation. Characteristically, the burrow had a single, somewhat ovoid opening of about $3 \mathrm{~cm}$ diameter. Passages ran parallel to and $3-5 \mathrm{~cm}$ below the surface. Most were of uniform diameter and length, about 3 and $35 \mathrm{~cm}$, respectively. Of 20 burrows I excavated all but 3 were simple, straight or slightly bent, dead end chambers. One very elaborate burrow was constructed by an adult male at the base and under a small greasewood shrub. It consisted of 4 branching passages, two of which possessed openings. Heatwole (1970) postulated that lizard burrows might be situated to take advantage of certain physical facts. For example, early morning sun into east facing burrows, late afternoon sun into west facing ones, and more insolation into south facing ones than those facing north. All burrows investigated had openings that faced east to northeast. Perhaps, early morning sun warms 
the openings thus preparing lizards for rapid emergence. At Frog Spring, basking G. wislizeni were never encountered in or near burrow openings. Since search often began an hour before basking individuals were first sighted, it would appear that emergence takes little time. A few burrow temperatures were recorded between 0800 and $0900 \mathrm{H}$ on warm sunny mornings. Taken at a depth of about $10 \mathrm{~cm}$, they ranged between 31.3 and $35.0^{\circ} \mathrm{C}$. This range is similar to $T_{B}$ of basking lizards captured during the hour.

Burrow construction took place in the afternoon only. Both sexes, juveniles and adults ( 73 to $102.5 \mathrm{~mm} \mathrm{SVL}$ ), were observed constructing burrows. The digging of one burrow, by a junvenile of $78 \mathrm{~mm}$ SVL, took an hour (1509 to 1609). The length of a burrow did not vary, greatly between sexes or with size. Only one lizard occupied a burrow at a time. Lizards were never observed entering the same burrow on two or more different days. During the summer, whether or not one burrow was used by several lizards is not known. Sometimes a burrow was constructed, then immediately abandoned. Perhaps its designer would return later. It seems each lizard constructs numerous burrows and probably is never far from one. Such a situation is of great thermoregulatory benefit to this wide ranging species.

Heat Stress

Cowles (1940) observed that some lizards are eurythermal with regard to activity range, but upward crowding 
of the optimum to a point just below lethal temperatures would make them stenothermal so far as tolerance to any further increase in concerned. The normal activity range for G. wislizeni observed in the field was found to fall between 28.0 and $42.0^{\circ} \mathrm{C}$. However, $52.9 \%$ of these values fell between 36.0 and $39.0^{\circ} \mathrm{C}$. Above $40^{\circ} \mathrm{C}$ the number of $T_{B}$ records declined abruptly. The maximum $\mathrm{T}_{B}$ recorded was $43.4^{\circ} \mathrm{C}$. Values exceeding $40^{\circ} \mathrm{C}$ probably represent temperatures of "maximum voluntary tolerance" (Cowles and Bogert, 1944). Temporary acceptance of $\mathrm{T}_{B}$ at levels of maximum voluntary tolerance is of benefit to lizard species and others, allowing them to store the maximum amount of heat practical without reaching physiologically damaging temperatures. In turn this would enable activity to occur for extended periods of time. However, prolonged exposure to such temperature levels could result in heat stress because lethal temperatures are just a few degrees higher. Panting is one of the first visual signs that a lizard is experiencing heat stress. Templeton (1960) thought panting functions as an additional adaptation to maintain loss of water at a constant rate and that it is not a mechanism which acts to lower the $T_{B}$ appreciably below that of the environment by intensive evaporative cooling. Though sometimes exposed to thermal conditions exceeding their normal activity range, G. wislizeni encountered during capture and observation procedure never showed panting 
behavior. This seems to indicate that either the level of $\mathrm{T}_{\mathrm{B}}$ at which panting occurs was not reached, or that $\mathrm{T}_{\mathrm{B}}$ level is not specific, but prevailing thermal conditions caused no immediate physiological hardship. If the first is correct, the fact that one non-panting individual possessed a $\mathrm{T}_{\mathrm{B}}$ of $43.4^{\circ} \mathrm{C}$ would indicate a high $\mathrm{T}_{\mathrm{B}}$ threshold for panting. An experiment was conducted to elucidate $\mathrm{T}_{B}$ at which panting would occur. Each of 25 different G. wislizeni were tethered in direct sunlight. Environmental temperatures for the two days of experimentation revealed the following ranges: $\mathrm{T}_{\mathrm{ASH}}, 32.8$ to $37.8^{\circ} \mathrm{C}$; TSSN always exceeded $51.0^{\circ} \mathrm{C}$; and $\mathrm{T}_{S S H}, 26.8$ to $34.1^{\circ} \mathrm{C}$. At the -onset of experimentation, chosen postures, largely $\mathrm{T}_{\mathrm{B}}$ associated, were variable. An adult female with a $T_{B}$ of $32.1^{\circ} \mathrm{C}$ spent the initial 23 seconds lying flat with venter and tail flush with the sand surface. A juvenile female with a TB of $38.1^{\circ} \mathrm{C}$ immediately assumed the "toes up and tail up" thermoregulatory posture. All lizards assumed toes up and tail up before engaging in other behavior, but promptly after doing so attempted to run in the direction of the nearest shade. Unable to reach shade in one direction, usually several attempts in other directions were taken. Running until the string was taut, in an effort to free themselves, several individuals would violently rotate their bodies a complete $360^{\circ}$. Based on other field observations, I believe such extreme activity contributed little 
to $T_{B}$ elevation. After each unsuccessful attempt to run to shade, the toes up and tail up posture was always resumed, and from it lizards would eventually begin panting behavior. The onset of panting in G. wislizeni occurred suddenly. Behavior included arched back, greatly compressed abdomen, slightly opened mouth, extended tongue engorged with blood, and shallow rapid ventilations (up to 125 per minute). The time elapsed between start of experiment and onset of panting ranged from 35 seconds to 9 minutes 53 seconds, and was highly correlated with the initial $T_{B}(t=6.1261, P<0.001)$. Mean $T_{B}$ and range at the sturt of the experiment were respectively $35.7^{\circ} \mathrm{C}$ (S.D. $=$ 1.9 ), and 32.1 to $38.3^{\circ} \mathrm{C}$. Mean $\mathrm{T}_{B}$ and range at the onset of panting were $40.9^{\circ} \mathrm{C}(\mathrm{S} . \mathrm{D} .=1.7)$ and 36.3 to $43.7^{\circ} \mathrm{C}$, respectively. Most of the $\mathrm{T}_{\mathrm{B}}$ of panting occurred near the upper limit of the normal activity range, a level designated as maximum voluntary tolerance. However, a few values were well below the upper limit. It would appear $\mathrm{T}_{\mathrm{B}}$ at which panting begins is not precise. Perhaps some physiological function - e.g., water balance - is responsible for initiating panting behavior. It is conceivable that under the intense thermal conditions at the time of experimentation, rate of water loss of G. wislizeni may have been. great.

No significant differences in response to heat stress were discovered between the sexes $(t=0.1538, P>0.50)$. 
Therefore, the data for the sexes were combined. Heat stress between adults and juveniles, SVL ranging from 71.5 to $100.0 \mathrm{~mm}$, was found not to show significant difference $(t=0.1042, P>0.50)$. However, individuals of shorter SVL were unavailable for testing. Hatchlings (45 to $50 \mathrm{~mm}$ ) exhibit different behavior from lizards in the size range tested (they spend most of the time close to shrubs): Different behavior permitted the few hatchling $\mathrm{T}_{B} \mathrm{I}$ recorded to be similar to $T_{B}$ values for larger lizards. How this might carry over to heat stress is not known.

Thermal Preference

In most organisms there is a specific temperature zone where biological processes occur with optimum efficiency. These zones are rigidly set in every species, but may vary in location on a scale and in size of range, from one species to the next. The "normal temperature" of man is actually an average for a zone between limits set. roughly at 37 to $37.5^{\circ} \mathrm{C}$. Lizards lack the complex internal regulating mechanism found in higher vertebrates. Consequently, in the face of changing weather conditions, they rely heavily on behavior to maintain a constant $\mathrm{T}_{\mathrm{B}}$ level. It seems, having only behavior at their disposal, that the precision with which they can maintain $\mathrm{T}_{\mathrm{B}}$ is greatly limited, thus forcing most to select a broader thermal zone. Studies so far indicate active lizards can operate at full efficiency at $\mathrm{T}_{\mathrm{B}}$ ranging over about $10^{\circ} \mathrm{C}$ (Cowles, 
1940; Bogert, 1959; and Lee and Badham, 1963). Roughly corresponding to the range 30 to $40^{\circ} \mathrm{C}$, this is called the range of normal activity. However, it would be interesting to know whether or not lizards, given the opportunity, would seek a more restricted thermal zone. Perhaps a specific temperature level of 2 or $3^{\circ} \mathrm{C}$ would be most frequently selected. In order to investigate the importance of thermal preference, I observed G. wislizeni in a thermal gradient on 4 successive days in both october and December, 1975. Assessment of temperature levels important to the species activity involved the use of terminology adopted by Licht et al. (1966a, 1966b). Mean maximal and minimal temperatures refer to the average of opposite extreme temperatures; mean preferred temperature (MPT) is an average based on all recorded temperatures. Provided with a wide choice of temperatures under the standardized conditions of a thermal gradient, mean minimal, maximal and preferred temperatures were determined from the total number selected by two representatives of $G$. wislizeni. The mean maximal and minimal values may assist in defining. upper and lower limits of the species preferred thermal zone; the mean preferred temperature may indicate the temperature level most desirable. For convenience, the individual lizards were described according to their sex, but it is not my intention to imply that temperature differences have any correlation with sex. 
The following information was taken from October's data. Considering each individual separately, mean time interval and mean daily $\mathrm{T}_{\mathrm{B}}$ did not fluctuate significantly. Comparison of both individuals revealed insignificant differences for mean time interval and mean daily $\mathrm{TB}$. It has alroady been mentioned that the combined values for both lizards for each time interval were insignificantly different from other intervals from 15 minutes on; the same is true for combined values on a day to day basis. Summing all values for each lizard separately, the mean female and male $\mathrm{T}_{\mathrm{B}}$ were 37.0 and $37.2^{\circ} \mathrm{C}$, respectively. These values proved not to be significantly different $(t=0.2317, P>$ 0.50) and were combined to arrive at a MPT of $37.1^{\circ} \mathrm{C}$ (S.D. = 2.3) .

Information from December data is less consistent. Both individuals showed $\mathrm{T}_{\mathrm{B}}$ levels for time intervals in the first hour to be significantly lower than at 4 hours. Mean $\mathrm{T}_{\mathrm{B}}$ for the male on day $1\left(32.9^{\circ} \mathrm{C}\right)$ and $2\left(36.9^{\circ} \mathrm{C}\right)$ were significantly different $(t=2.1457, P<0.05)$. A comparison between the two individuals showed mean $\mathrm{T}_{\mathrm{B}}$ at hourly intervals to demonstrate significant differences similar to those for each individual treated separately. On day 6 the mean $\mathrm{T}_{B}$ of the male $\left(36.9^{\circ} \mathrm{C}\right)$ was significantly higher $(t=$ $2.4303, \mathrm{P}<0.05)$ than the female $\left(33.1^{\circ} \mathrm{C}\right)$. Combined values for both lizards at hourly intervals were previously shown to have significant differences between 15 minutes 
and 1 hour, and 1 hour and 4 hours. Daily mean $T_{B}$ of combined values showed no significant differences. Summing all values for each lizard separately, the mean female and male $\mathrm{T}_{B}$ were respectively, 34.3 and $33.7^{\circ} \mathrm{C}$. These values proved to be insignificantly different $(t=0.3608, P>$ 0.05 ) and were combined to arrive at a MPT of $34.0^{\circ} \mathrm{C}$ $(S . D .=6.6)$.

The mean minimal values for October $\left(33.9^{\circ} \mathrm{C}, \mathrm{S} . \mathrm{D} .=\right.$ 2.8) and December $\left(27.8^{\circ} \mathrm{C}, \mathrm{S} . \mathrm{D} .=3.6\right)$ revealed a highly significant difference $(t=3.7533, P<0.01)$, but the mean maximal value for the former month $\left(39.4^{\circ} \mathrm{C}\right.$, S.D. $\left.=1.8\right) \mathrm{did}$ not differ significantly $(t=1.2479, P>0.10)$ from the latter month $\left(38.3^{\circ} \mathrm{C}, \mathrm{S} . \mathrm{D} .=1.6\right)$. The difference in mean minimal values can be attributed to consistency in behavior. In October both lizards usually emerged quickly and remained active until the lights were turned off; but in December time of emergence was variable, and activity irregular with retreat occurring at anytime. Reduced activity in December, in the presence of favorable environmental temperatures, seems to indicate the influence of some biological rhythm. The lizards would warm to optimum levels in both months, but in December frequent emergingretreating behavior appears to reflect a conflict between temperature dependent emergence and temperature independent drive to hibernate.

For this reason it appears only October data can be 
accepted as reliable in assessing thermal preferendum. 77.4\% of al1 October temperatures were within the mean minimum-maximum range $\left(33.9\right.$ to $\left.39.4^{\circ} \mathrm{C}\right)$. Of the total $\mathrm{T}_{B}$ recorded in the field, $80.2 \%$ were between $32^{\circ}$ and $40^{\circ} \mathrm{C}$. For similar percentages, this is a difference of $3^{\circ} \mathrm{C}$. Even more enlightening is the fact that $61.3 \%$ of the October TB fell within the narrow range of 36 to $39^{\circ} \mathrm{C}$. These findings appear to indicate that given a wide choice of temperatures from which to choose (a situation infrequently occurring in nature), G. wislizeni can thermoregulate with precision.

Home Range Size and Territoriality

Studies at Frog Spring in 1974 and 1975 encompassed roughly early and mid summer. Home range size is interpreted as the area occupied by a given lizard during those two summers. However, because of the unusual geographical and vegetational barriers surrounding Frog Spring, I would not be surprised if lifetime home range size for some individuals is not.greater than the area occupied during the period of study.

Estimation of home range size involved computing the area of plotted "convex" polygons. The total number of square meters in a polygon was interpreted as the minimum area occupied by a lizard. For most lizards, two areas were computed in this manner. One area, based on accumulation of all sighting points (including those established 
during hourly observations), represented the greatest minimum area. The other, based on only initial sighting points, represented a slightly smaller minimum area. The number of hourly observations made on each lizard varied. Some individuals were never observed for an hour. Generally speaking, lizards most often observed for hourly periods provided more sighting points. To reduce bias due to varying number of points, when assessing the area occupied by different sexes or sizes, only the areas of first sighting were used.

In order to investigate the stability of home range size in G. wislizeni it is necessary to see if area increases with an increase in number of sightings. This task was accomplished for every lizard sighted from 3-16 times. Table VIII shows the number of individuals captured 3 or more times, and the average home range size. These average figures were plotted on graph paper (as the ordinate) with the number of sightings. Points of inflection on curves were interpreted as possibly indicating minimum home range size.

When the areas of adult males were combined and averaged for each sighting point level an inflection on the curve occurred at 9, 11 , and 12 sightings (Figure 17). These numbers may be indicative of minimum home range size for males. The size of the home range with increasing number of sightings was plotted for each individual. Four 
TABLE VIII. HOME RANGES $\left(\mathrm{M}^{2}\right)$ COMPUTED ON THE BASIS OF 3 OR MORE SIGHTINGS. NUMBERS IN PARENTHESES ARE NUMBERS OF INDIVIDUALS.

\begin{tabular}{l|c|c|c|c|c|c|c|c|c|c|c}
\hline & \multicolumn{10}{|c}{ NUMBER OF SIGHTINGS } \\
\cline { 2 - 10 } & 3 & 4 & 5 & 6 & 7 & 8 & 9 & 10 & 11 & 12 & 13 \\
\hline ADULT MALES & $430(11)$ & $997(9)$ & $1879(6)$ & $2472(6)$ & $3226(4)$ & $3660(3)$ & $2625(2)$ & $3755(2)$ & $3755(2)$ & $3529(1)$ & $4932(1)$ \\
ADULT FEMLLES & $116(11)$ & $353(8)$ & $507(5)$ & $686(4)$ & $1201(4)$ & $1259(3)$ & $1437(2)$ & $1437(2)$ & $1978(1)$ & $2236(1)$ & $2254(1)$ \\
JUVENILES & $168(11)$ & $389(7)$ & $762(5)$ & $831(2)$ & $1068(1)$ & $1229(1)$ & - & - & - & - & - \\
\hline
\end{tabular}


76

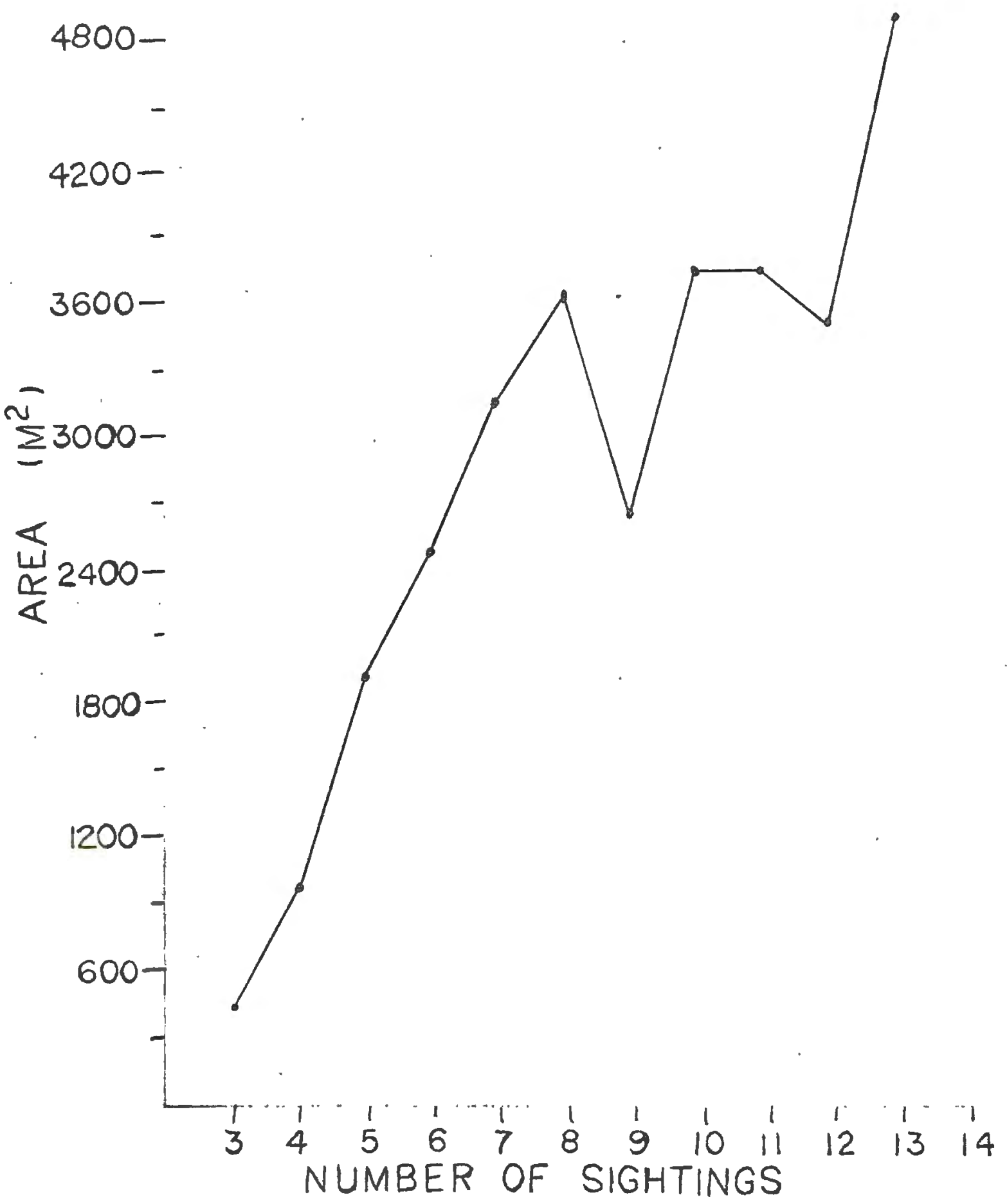

Figure 17. Average home range area of adult male Gambelia wislizeni at indicated number of sightings. 
times the curve had an inflection at six sightings, 2 times at 8 , and 2 times at 11 . Thus, for some males, during the period of investigation, minimum home range size might be accurate at 11 sightings. Unfortunately, most males were not sighted 11 times. The curve of several individuals did not show inflection at any number of sightings. The home range size for two males sighted 11 or more times was $4457.5 \mathrm{M}^{2}$ (11 sightings) and $4932.3 \mathrm{M}^{2}$ (13 sightings). However, a maximum area of 10,215.2 $\mathrm{M}^{2}$ was occupied by one male sighted 8 times. Since this individual was observed for a brief time, spanning about 2 months, one might question the validity of estimating home range size in the manner just described. Certainly the speculation of Tanner and Krogh (1974) regarding nomadism in G. wislizeni is a possibility. However, only the data for this one individual departs greatly from that for others. Most males, which were frequently active covered a considerable area. Probably some activity was overlooked; nevertheless, it is apparent that some individuals occupied larger areas than others during the period of study. Whether any individual occupied a definable home range is doubtful. The average of combined home range size for each sighting point level in adult females showed inflection on the curve at 8 and 10 sightings (Figure 18). Plotting home range size with increasing number of sightings in each individual showed inflection on the curve occurring once at 


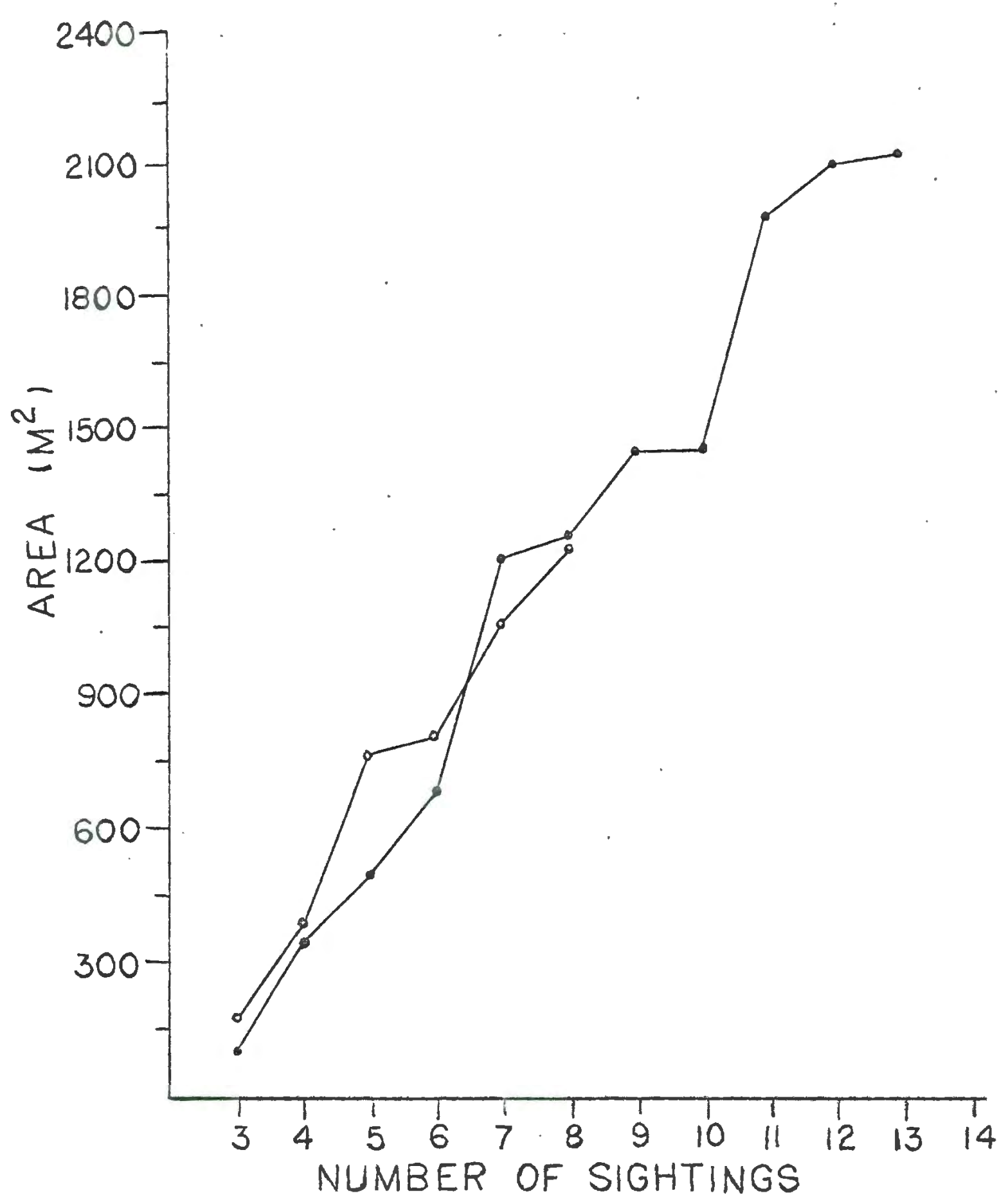

Figure 18. Average home range area of adult female (dots) and juvenile (circles) Gambelia wislizeni at indicated number of sightings. 
6 sightings, 3 times at 8 sightings, once at 10 sightings and once at 13 sightings. Thus, in some females, minimum home range might be accurate at 8 sightings. One individual, observed both summers, showed inflection on the curve at 8,10 , and 13 sightings. These sightings were separated by 11 months and 1 month respectively, and perhaps indicate home range shift. At each sighting point level, the average home range size for adult males always greatly exceeded that for adult females. The home range size of 3 adult females sighted 8 or more times were $1186.6 \mathrm{M}^{2}$, $1542.0 \mathrm{M}^{2}$, and $3,772.6 \mathrm{M}^{2}$. The last value was the largest for any individual. Adult females were encountered less frequently than adult males. Two individuals were not sighted for a period of about 12 months. However, both individuals were sighted within $30 \mathrm{M}$ of where they were last sighted. This close approximation of two points, widely spaced temporally, may indicate selection of a definite home range. Further indication of a preference for a particular area was demonstrated by individuals which showed no home range expansion in later sightings. For example, one individual sighted 10 times, showed no home range expansion after sighting number 7. From the data, it is apparent that infrequently active adult female $G$. wislizeni occupy similar small areas and it appears possible that home range area, allowing for an occasional shift, is definable. Home range data on juveniles are considerably fewer. 
so data for the sexes are combined. The average of the combined areas for each sighting point level showed an inflection of the curve to occur at number 6 sighting (Figure 18). Home range size plotted with increasing number of sightings showed inflection of the curve at number 6 sighting for one individual. All other individuals showed no curve inflection at any number of sightings. Perhaps this situation is an indication of juvenile dispersion. However, home range size increased very gradually for each indicidual. The largest home range size for a juvenile was that of a male sighted 8 times $\left(1228.7 \mathrm{M}^{2}\right)$.

Though home range size is largely undetermined for any of the groups discussed above, size difference may be elucidated somewhat by figuring the average area added with each new sighting point. Summing added areas for all individual adult males, adult females, juvenile males and juvenile females the averages for each group were computed. Adult males clearly showed the largest average for area added $\left(630.6 \mathrm{M}^{2}\right)$. The other groups showed similar values for the average of added areas, adult females $\left(259.8 \mathrm{M}^{2}\right)$, juvenile males $\left(223.2 \mathrm{M}^{2}\right)$ and juvenile females $\left(218.8 \mathrm{M}^{2}\right)$. The average area added for juvenile males and females proved not to be significantly different $(t=0.0873, P>0.50)$ and these groups were combined for comparison with adults. Average area added for adult males proved significantly larger than average area added for adult females $(t=$ 
$3.0958, P<0.01)$, and juveniles $(t=3.1310, P<0.01)$. Average area added for adult females and juveniles were not significantly different $(t=0.1345, P>0.05)$. The average area added is a strong indication of movement, and whether or not any of the groups possess a definable home range, it appears that area covered by adult males is more than two times that for adult females and juveniles.

Territoriality as defined by Burt (1943) possibly occurred on two occasions. Both involved adult-juvenile confrontation. Each time the adult chased an intruding juvenile, snapping viciously at its posterior. Perhaps such behavior was indicative of predator-prey activity, as it is known G. wislizeni feeds on smaller lizards, including members of its own species. However, both juveniles were of fairly. good size (70 to $75 \mathrm{~mm}$ SVL) and were probably much larger than usual food items (Pianka, 1976). Both times pursuit was initiated by the juvenile moving under a shrub very near the locality occupied by the adult. Reaction on the adult's part appeared more in the order of defense than feeding. The disturbed adult pursued the juvenile into the open. On one occasion after running about 4 meters the adult discontinued the chase. In the other instance, the fleeing juvenile abruptly halted and turned to face its pursuer. After each lizard attempted several bites about its opponent's head and neck region, they locked jaws. For the next 10 minutes a violent tug- 
o-war ensued, neither individual relinquishing its hold. A capture effort on my part caused each to let go.

Perhaps home range location and extent of overlap gives some indication of territoriality. of 22 juveniles marked at Frog Spring, only 2 were initially sighted more than $35 \mathrm{M}$ inward from the site's perimeter. AlI but one juvenile home range existed near the sites perimeter (Figure 19). Adult-juvenile home range overlap occurred frequently, but some areas occupied by certain juveniles, being quite small and situated very near the site's edge, remained separated from areas occupied by adults. Excluding area supporting suboptimal habitat, adult home ranges were situated over the entire site. However, with respect to the site, most were centrally located. Home range overlap was extensive among adult males, each individual's area overlapping the area of several others (Figure 20). One wide ranging individual possessed a home range which overlapped those of 6 other males. Eleven adult males wero sighted 3 or more tines. The total area occupied by these individuals $\left(33,626 \mathrm{M}^{2}\right)$ exceed that of the site $(27,871$ $\mathrm{M}^{2}$ ). Adult male and female overlap was just as extensive. Portions of 7 female home ranges were within the area covered by one male. Compared with males, home range overlap in females was, greatly reduced (Figure 21). In most cases a projection of one arm of the home range of an individual barely protruded into the home range of another. 


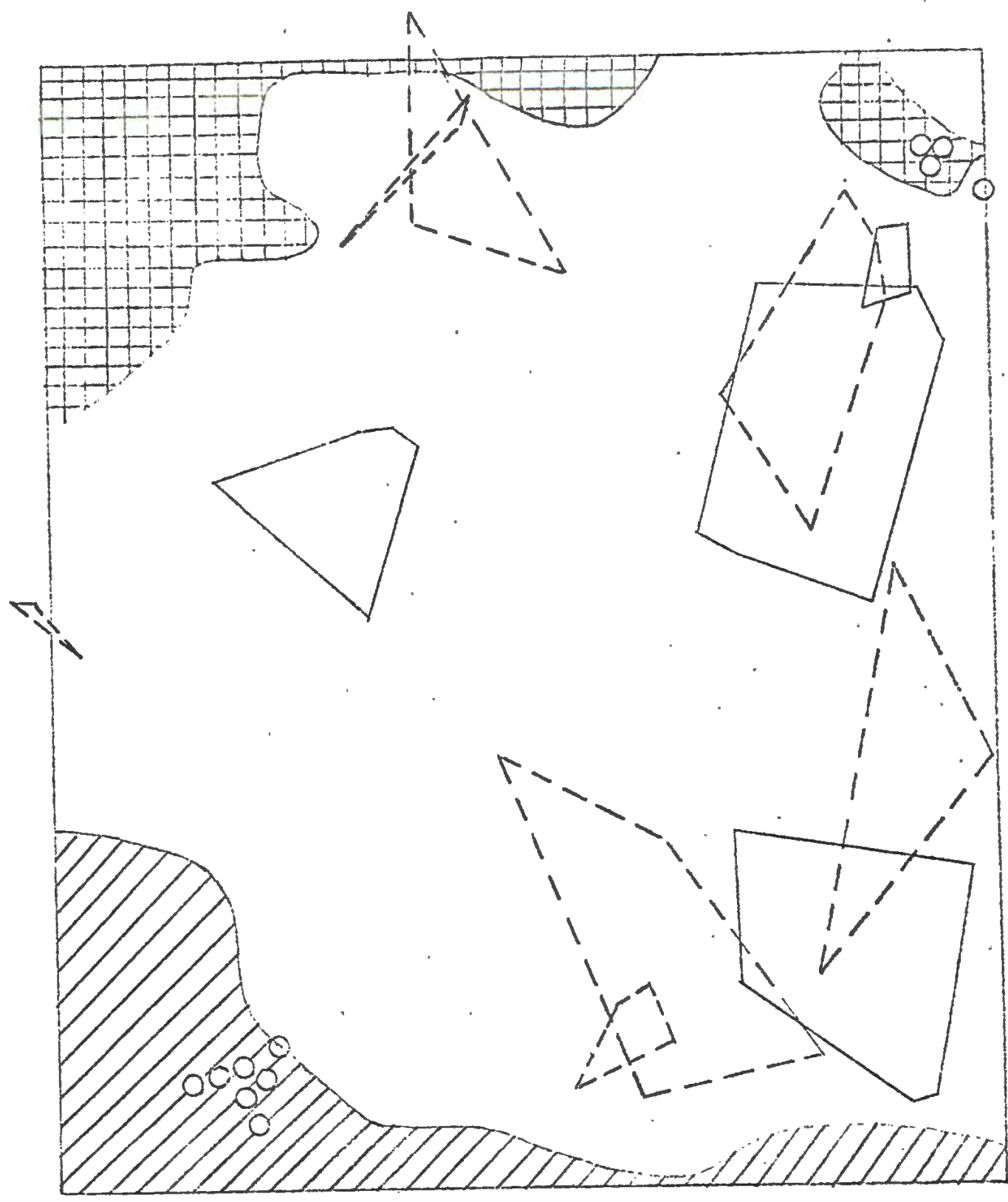

Figure 19. Home ranges of juvenile males (solid lines) and females ((broken lines) Gambelia wislizeni at Frog Spring. Cross hatched areas indicate dense shrubs (mostly big sage and rabbitbrush). Slanted lines indicate grassy areas. Circles represent individual Russian 0live shrubs. 


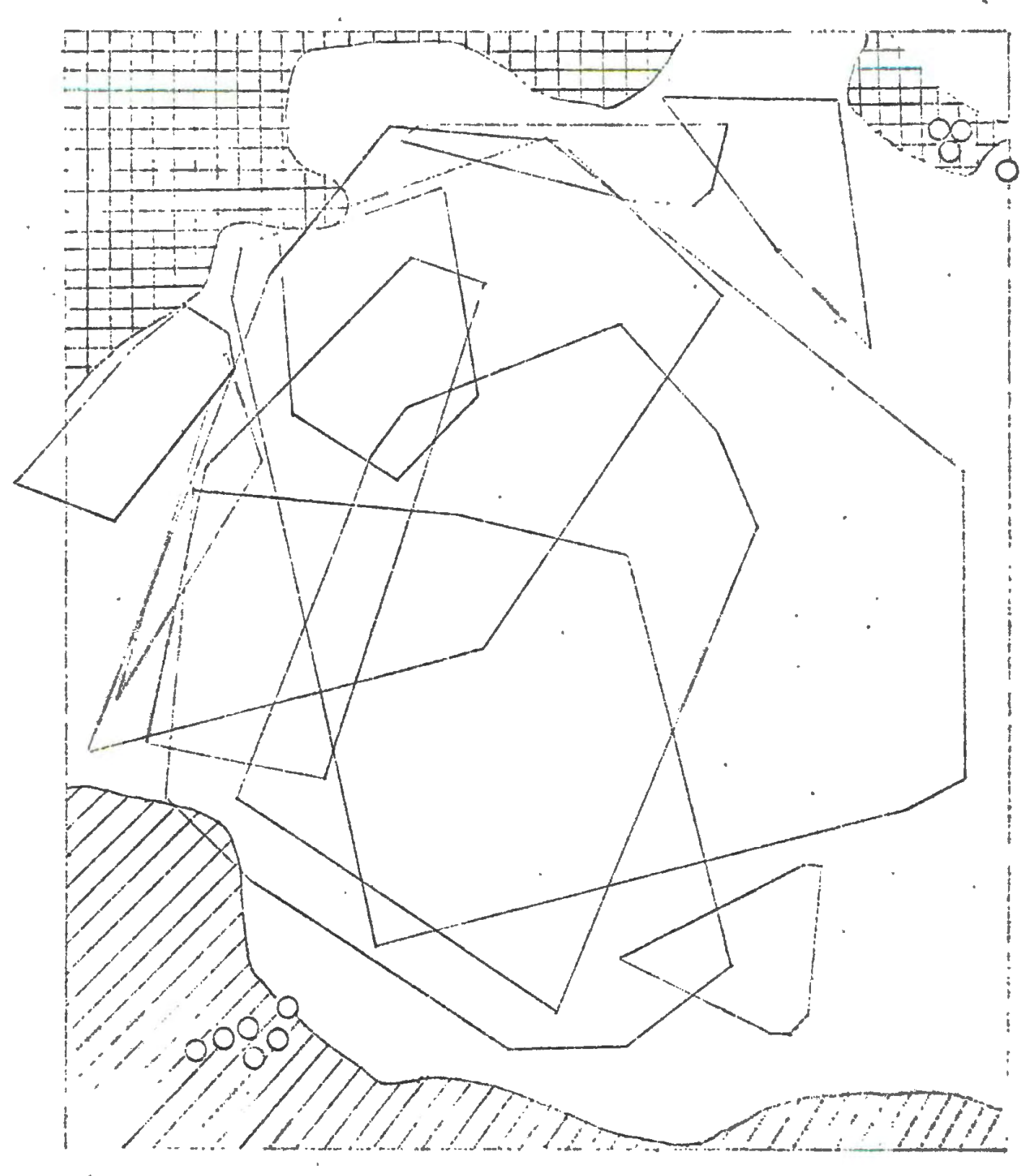

Figure 20. Home ranges of adult male Gambelia wislizeni at Frog Spring. Symbols the same as in Figure 19. 


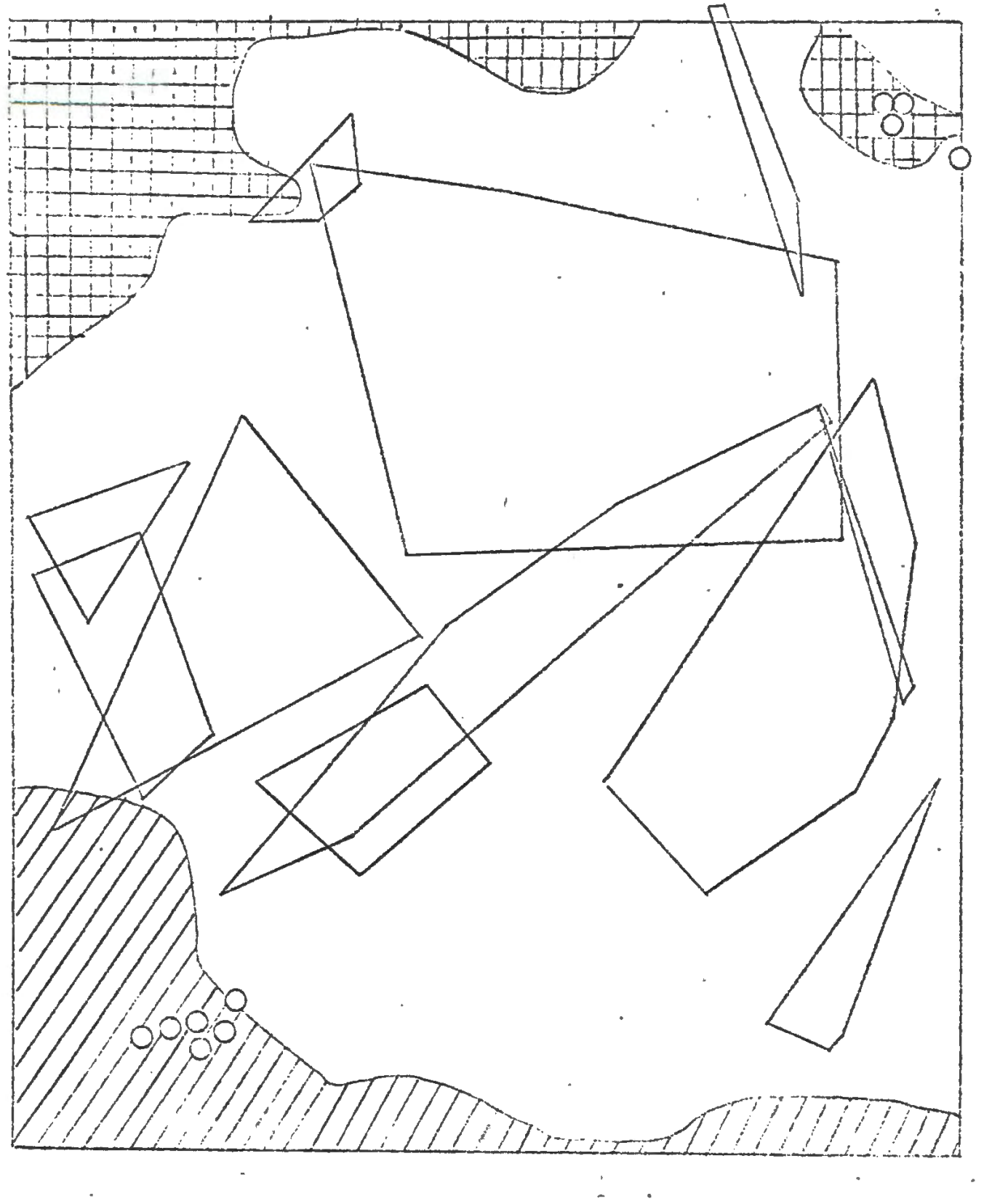

Figure 21. Home ranges of adult female Gambelia wislizeni at Frog Spring. Symbols the same as in Figure 19 . 
Overlap between females never amounted to more than 3 individuals. Reduced overlap of home range in adult females is probably not the result of occupancy of smaller area. UsualIy when the home ranges of two females showed considerable overlap, one of the individuals had not been seen since the previous summer. Perhaps this illustrates home range expansion due to the death of the long unseen individual. The home ranges of two females, occupying areas larger than some males, showed little overlap from other females. Thirteen adult females were sighted a minimum of 3 times. The total area occupied by these individuals covered a little better than a third of the site $\left(10,693 \mathrm{M}^{2}\right)$. There may be several reasons for reduced overlap among adult females but they all probably deal with reproduction.

Because feeding appears to be a gorging and resting procedure, feeding individuals are often inactive and are not likely to be observed regularly (Tanner and Krogh, 1974). The infrequency with which some females were sighted was already mentioned. Adult males and juveniles were encountered much more frequently than adult females. However, in both sexes and all stages of development for which lizards were marked $(60.5 \mathrm{~mm}$ to $112.5 \mathrm{~mm} \mathrm{SVL})$, some irregularity in activity was observed. Generally speaking, an individual was active up to several days in succession, and then was not sighted for periods of time varying from a few days to 2 or 3 weeks. For instance, an adult female 
observed numerous times in both summers revealed the following activity pattern. During 1974 she was first seen on $12 \mathrm{July}$, but not seen again until 23 and $24 \mathrm{July}$. For the remainder of the summer she was active on $2,6,7,10$, and 18 - 20 August. In 1975 this individual was sighted 22 - 26 June (excluding 24 when unseasonal weather prevailed), and again on 29 June, 1 and $19 \mathrm{July}$, and 10 and 11 August. With such inactivity, coupled with my inability to be in the field every day of each summer, the incompleteness of using home range area alone as a measuremnt of movement becomes evident. It was impossible to determine the cxtent of movement between sightings. Another method employed in the analysis of movement involved constant observation for a certain time interval. At Frog Spring, $G$. wislizeni were observed continuously for periods of approximately an hour. Kinds of movement were noted and a comparison of distance traveled per hour was made between males and females and adults and juveniles. Later, for each individual, the total didstance traveled $\left(\mathrm{M}^{2}\right)$ in the hour was calculated.

Kinds of Movements

At environmental temperatures within the range supporting activity several factors, including overcast skies, strong, gusty winds and periods of maximum solar radiation, inhibited movements. However, even when these factors persisted, some movement was detected. Not enough observa- 
tion was made for analysis of daily times promoting maximum movement. It appears prevailing weather conditions, rather than time, were most influential on movement. It is difficult to catagorize the kinds of movement in G. wislizeni. Usually, one quickly but gracefully blended into another. Nevertheless, 3 basic movements can be separated on the basis of activity pattern.

Exploratory movement was most frequently encountered. This usually preceeded and followed all other kinds. Characteristics of exploratory movement included: a pace which varied between a walk and a trot; a route which rarely demonstrated uniform direction (often a zig-zag pattern); frequent pauses usually lasting a few seconds; and numerous tongue flicks to the ground and objects. The last served a gustatory-olfactory function. When sand surface thermal conditions exceeded the range of activity, exploratory behavior remained unaltered, except that the pace was accelerated.

Movement associated with feeding was observed on many occasions. Generally, it consisted of two primary kinds of behavior. Most frequently noted was the "sit and pounce". G. wislizeni is extremely quick and its movement displays considerable agility. Usually, a lizard was observed resting in shade. Demonstrating occasional "alerting movements", it would suddenly dart in the direction of a moving prey. On two different days I tossed pebbles of insect 
size in front of individual G. wislizeni. Every time the lizards reacted with the same pouncing behavior. This behavior was elicited when pebbles landed 5 to $10 \mathrm{M}$ from the lizard. Insects passing overhead were subject to the same sort of response. On several occasions a lizard leaped straight up from its resting position to attempt capture of a fly or grasshopper (twice capture was successful). Using this tactic, one individual was observed leaping as high as 40-4.5 cm. The second kind of feeding movement involved actual "stalking" of prey. Description of one observation noted in August 1974 best exemplifies the behavior. An adult femalo was sighted moving in broken shade alongside a greasewood shrub. Maintaining a low profile, her venter made contact with the sand. Her head was oriented upward at about $45^{\circ}$, and it appeared she was watching something. Taking cautious steps, she advanced slowly, but continu-. ously. After covering about 2 meters of ground in this manner she paused. For about 30 seconds, maintaining a crouched posture with head directed upward, she remained still. Suddenly, she darted forward about a meter to another greasewood, and without pause climbed swiftly about $60 \mathrm{~cm}$ up into the shrub and seized a grasshopper.

The third kind of movement occurred when G. wislizeni were startled. Usually, presence of a potential predator elicits this kind of movement, but a variety of noises or a sudden gust of wind may do so also. A startled lizard 
exhibits a running movement which at top speed may be bipedal. The distance covered is extremely variable, ranging from less than a meter to over $30 \mathrm{M}$. Most often the movement involves running straight from one shrub to another, a distance of approximately 5 to $10 \mathrm{M}$.

Distance Traveled per Hour

Distance traveled per hour, calculated from data gathered during 57 separate observations, reveals a movement pattern in accord with the one found for home range size. Comparing sexes and sizes, adult males were found to greatly exceed all other groups in average distance traveled (42.6 M) per hour. Adult females averaged considerably less than adult males ( $14.8 \mathrm{M}$ per hour). Only 3 juvenile females were studied in this manner, so they were combined with juvenile males and both groups were evaluated as one. Juveniles' average distance traveled did not greatly exceed that of adult females ( $18.6 \mathrm{M}$ per hour). The correlation of movement per hour between these groups showed that adult males traveled significantly greater distances than did adult females $(t=3.2017, P<0.05)$. Adult females and juveniles did not travel distances which were significantly different $(t=0.5441, P>0.050)$. The number of moves per hour were noted for each individual, but because many movements involved turning in place or advancing only a few centimeters (position and posture changes) the validity of number of moves in evaluating total distance is 
questionable. Consequently they are not presented. The distance traveled per hour was variable and was greatly influenced by weather. During periods of overcast skies or high solar radiation some individuals (both sexes and a variety of sizes) moved only 30 to $50 \mathrm{~cm}$ in an hour, never leaving the shelter of a particular shrub. Maximum distance traveled was extensive in some, and many of the influential factors remain unclear. Five males exceeded 50 meters in an hour $(122.1,118.1,108.7,62.6$, and 53.2). The maximum distance traveled by adult females was $35.1 \mathrm{M}$. One male and female juvenile moved 34.4 and $27.9 \mathrm{M}$, respectively. The longest individual move during the hour of observation was a little less variable between the groups, but adult males still provided the greatest distance (13.4 M). Longest moves for adult females, and juvenile males and females were $10.4,4.0$, and $5.2 \mathrm{M}$, respectively. However, one juvenile female, startled by a passing whipsnake, Masticophis taeniatus, ran bipedally $11.0 \mathrm{M}$.

Some factors important to the biology of G. wislizeni have a profound effect on movement.

Relation of Environmental Temperatures to Distance Traveled per Hour

At Frog Spring, movement in G. wislizeni seemed to follow normal routine. Environmental temperatures were recorded every half hour. Body temperature was recorded at the end of the hour of observation. A valid argument 
concerning the accuracy of this method is obvious. Environmental and body temperatures can fluctuate considerably in an hour. Fortunately, during my observations, changes in environmental temperature never amounted to more than a few ${ }^{\circ} \mathrm{C}$. I believe such changes did not alter the general course of behavioral events in G. wislizeni. Movement. in G. wislizeni was greatly retarded when $T_{B}$ could not be maintained within the normal activity range. However, at $T_{B}$ within this range, movement occurred over a wide range of environmental temperatures. It would appear the effect of environmental temperatures on movement is directly linked with their effect on ${ }^{-} T_{B}$. $T_{A S H}$ showed very little correlation with movement $(t=0.9234, P>0.50)$. This is understandable since G. wislizeni seems to obtain most thermal energy from solar radiation and conduction from the sand. Both TSSN $(t=2.328, P<0.05)$ and $T_{S S H}$ $(t=2.4310, P<0.05) \cdot$ showed significant correlation with movement. Generally, distance traveled was correlated with rising sand surface temperatures. This seems to contradict the idea that lizards avoid extreme thermal conditions. However, whenever considerable movement occurred at high TSSN and TSSH, T Still remained well below maximum voluntary tolerance. The highest $\mathrm{T}_{B}$ recorded after hourly observation was $37.8^{\circ} \mathrm{C}$. Under warm conditions, individuals unable to maintain $\mathrm{T}_{\mathrm{B}}$ below maximum voluntary tolerance probably retreated to deep shade or burrows. It 
is interesting to note that at very high $\mathrm{T}_{\mathrm{SSH}}\left(35\right.$ to $\left.40^{\circ} \mathrm{C}\right)$, many individuals wero obsorved moving in shado through and around a shrub, or from the shade of onc shrub to another. This behavior probably illustrates the difficulty in finding TSSH low enough to aid in maintenance of a constant TB. Apart from hourly observations, some individuals captured after moving considerable distances, were found to have $T_{B}$ near maximum voluntary tolerance. To risk thermal stress might indicate that movement is influenced somewhat by . physiólogical factors other than temperature. ।

Relation of $\mathrm{T}_{\mathrm{B}}$ to Distance Traveled per Hour

Unfortunately, during the hours of observation, $\mathrm{TB}$ at selected time intervals were unattainable. Probably, the $\mathrm{T}_{\mathrm{B}}$ of individuals fluctuated a few ${ }^{\circ} \mathrm{C}$ in the course of an hour. $T_{B}$ recorded at the end of the hour showed a strong correlation with movement $(t=5.1841, P<0.001)$. The greatest distances traveled by $G$. wislizeni occurred at $T_{B}$ considerably below the thermal preferendum determined in a thermal gradient. Movements in which $\mathrm{T}_{\mathrm{B}}$ were recorded show maximum distances occurring near the mean established in the field. The inability to record $T_{B}$ during actual movement discouraged predictions on $\mathrm{T}_{\mathrm{B}}$ most important to movement. Nonetheless, based on end of the hour records, movement occurred over a wide range of $\mathrm{T}_{\mathrm{B}}$. I suspect these records help support the idea of normal activity in many lizard species being temperature independent over a relatively 
broad range of $\mathrm{T}_{\mathrm{B}}$ (Lee and Badham, 1963).

Relation of Size and Body Proportions to Distance Traveled per Hour

Snout-vent length (SVL), weight, and hindlimb and forelimb percentages of SVL were analyzed for their relationship to movement. SVL of different G. wislizeni observed for periods of an hour ranged from 71 to $102 \mathrm{~mm}$. For this size range SVL proved to be insignificantly correlated with movement $(t=1.1963, P>0.10)$. It would be interesting to see if individuals smaller than the smallest obscrved comply to this relationship. Body weight of different G. wislizeni observed for periods of an hour ranged from 6.3 to $33.7 \mathrm{~g}$. For this range body weight does not appear correlated with movement $(t=1.5076, P>0.10)$. Turner et al. (1969) reported that home range size in 1izards is proportional to body weight. However, as with SVL, body weight shows no relationship with linear distance traveled. Forelimb and hindlimb lengths were expressed as a percentage of SVL (Pianka and Parker, 1972). While forelimb-SVL\% does not show correlation with movements $(t=$ $0.9856, P>0.10)$, hindlimb-SVL $\%$ is significant $(t=2.1013$, $P<0.05)$. This is what one might expect of a lizard demonstrating the behavior of G. wislizeni. Exceptional hindlimb length is necessary in a species that makes a living by frequent trips over considerable ground offering only harsh thermal conditions and little concealment. 
Individuals with larger hindlimb-SVL: may be better adapted to cover greater distances.

Relation of Sex to Distance Traveled per Hour

The sexual status of G. wislizeni is significantly correlated with movement $(t=2.6167, P<0.02)$. It has already been shown that adult males travel greater distances per hour than adult females. It's unfortunate that a greater number of juvenile males and females were not observed. The maximum distance traveled in juvenile males and females were very similar.' It would be interesting to know if such similarity is found for both sexes at all stages of growth.

Relation of Time of Day to Distance Traveled per Hour

The time interval in which a lizard was observed proved significantly correlated with movement $(t=2.3620$, $\mathrm{P}<0.05)$. Longest distances traveled increased after emergence until at least $1500 \mathrm{H}$ (unfortunately only a few hour observations were made after this time). One adult male covered a distance of $122.1 \mathrm{M}$ during the interval 1418 to $1518 \mathrm{H}$. Minimum distances traveled were most evident from 1000 to $1400 \mathrm{H}$, a period corresponding to most intense solar radiation. It was previously mentioned that $G$. wislizeni showed a bimodal activity pattern on warm days, but resorts to peak activity at almost any time within its activity period if the weather is cool. Several lengthy 
distances were covered by individuals observed on warm days between 0800 and $1000 \mathrm{H}$. However, it was unintentional that numerous hour observations were conducted on days when the weather was unseasonally cool. At least in part, cool weather seems responsible for the increase in distance traveled with passing time. With seasonal weather, I suspect.greatest movement occurs at times when $\mathrm{T}_{B}$ is most easily maintained within the normal activity range. This situation is best accomplished under a bimodal activity pattern.

Mean Direction and Circular Variance

An attempt was made to ascertain the extent to which movement of G. wislizeni are random. If they are truly nomadic, one might expect movement to reveal considerable randomness. In sequence, from first to last sighting, an angle was calculated for the direction from one point to the next. Angle values were then plotted on a circle for adult males, adult females, and juveniles (Figure 22). Mean direction and circular variance were calculated for each of these groups. The mean directions for adult males $\left(197^{\circ}\right)$, adult females $\left(261^{\circ}\right)$, and juveniles $\left(219^{\circ}\right)$ roughly corresponded respectively to south, east, and southeast. The circular diagrams seem to indicate random movement. Computation of circular variance $(I-\bar{R})$ leaves little doubt about the matter. Variance values for adult males (.9552), adult females (.8057), and juveniles (.7747) were 
DIRECTIONAL MOVEMENT $\left.1360^{\circ}\right)$
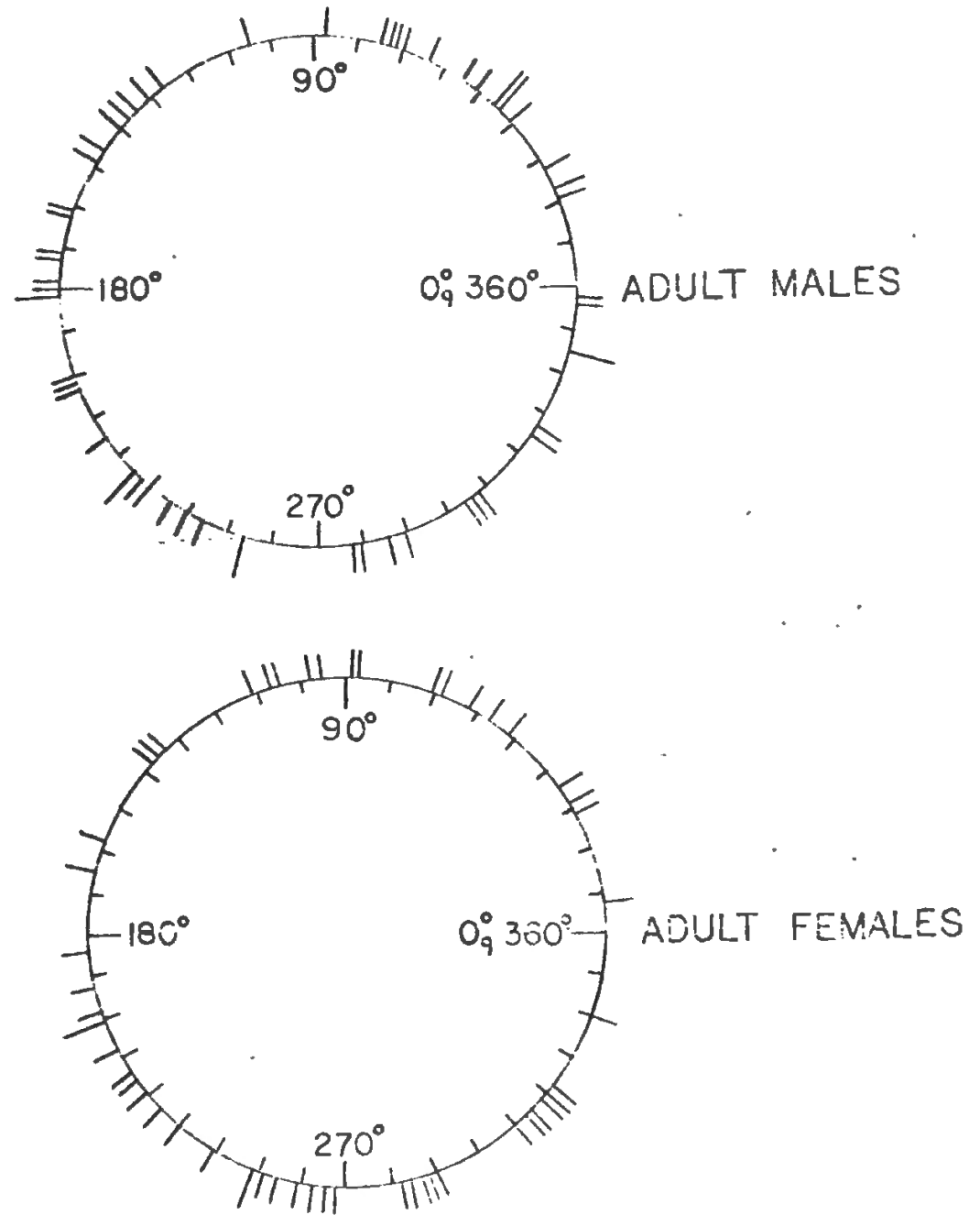

DIRECTIONAL MOVEMENT 13E0':

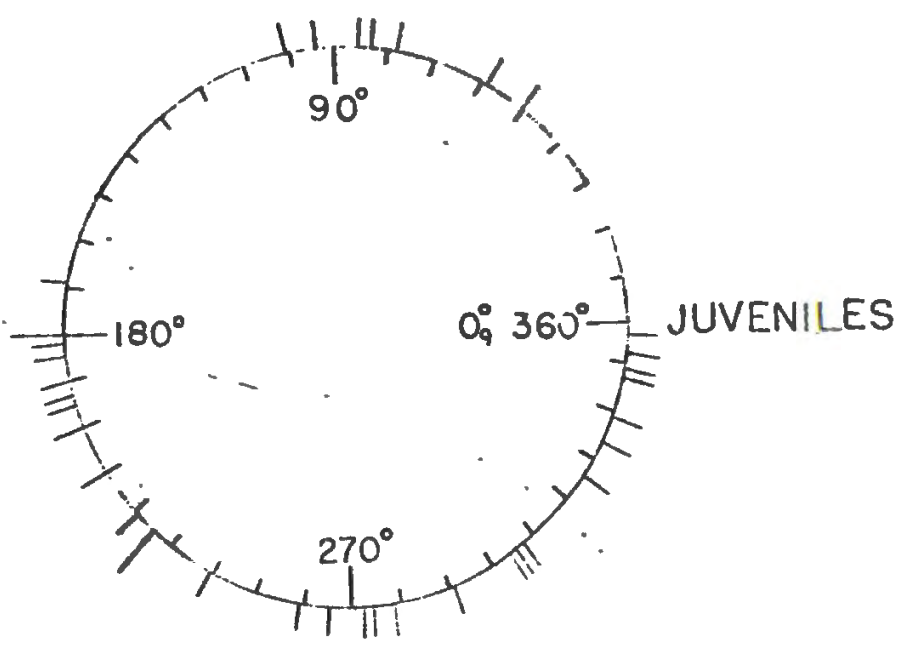

Figure 22. Circular plotting of directional movement in Cambelia wioliaeni at Frog Spring. Longer lines represent two identical values.

$\stackrel{\bullet}{v}$ 
extremely high, thus confirming that movement in G. wisi $i z e n i$ is indeed of a random nature. However, random movement seems to occur primarily within the confines of the site. During the two summers, not one marked individual traveled in excess of $30 \mathrm{M}$ beyond the research site's boundary (Figure 23). This probably reflects avoidance of the suboptimal habitat which nearly surrounds the site (see description of study site). In support of this apparent barrier, the few lizards marked off the site, (beyond the suboptimal habitat) never were encountered at a later date on the site. Therefore, movement of the entire season show some orderly direction; most lizards move in directions which keep them on the site. Perhaps, over the course of a few years some immigration and emigration might occur, but it appears it would be meager.

At Frog Spring, the plotting of sighted individuals was conducted from early to mid summer. This period is largely post-reproductive; all adult females encountered at the site were spent. At this time juvenile G. wislizeni are dispersing. With respect to the locations in which hatchlings and juveniles were first encountered it appears they are gradually moving from the perimeter to the sites interior. All hatchlings and most juveniles were first sighted in the extreme west, northwest, and north portions of the site. Hatchlings were never found more than $30 \mathrm{M}$ inward from the perimeter. Perhaps egg-laying localities 


\section{OFF-SITE ACTIVITY}

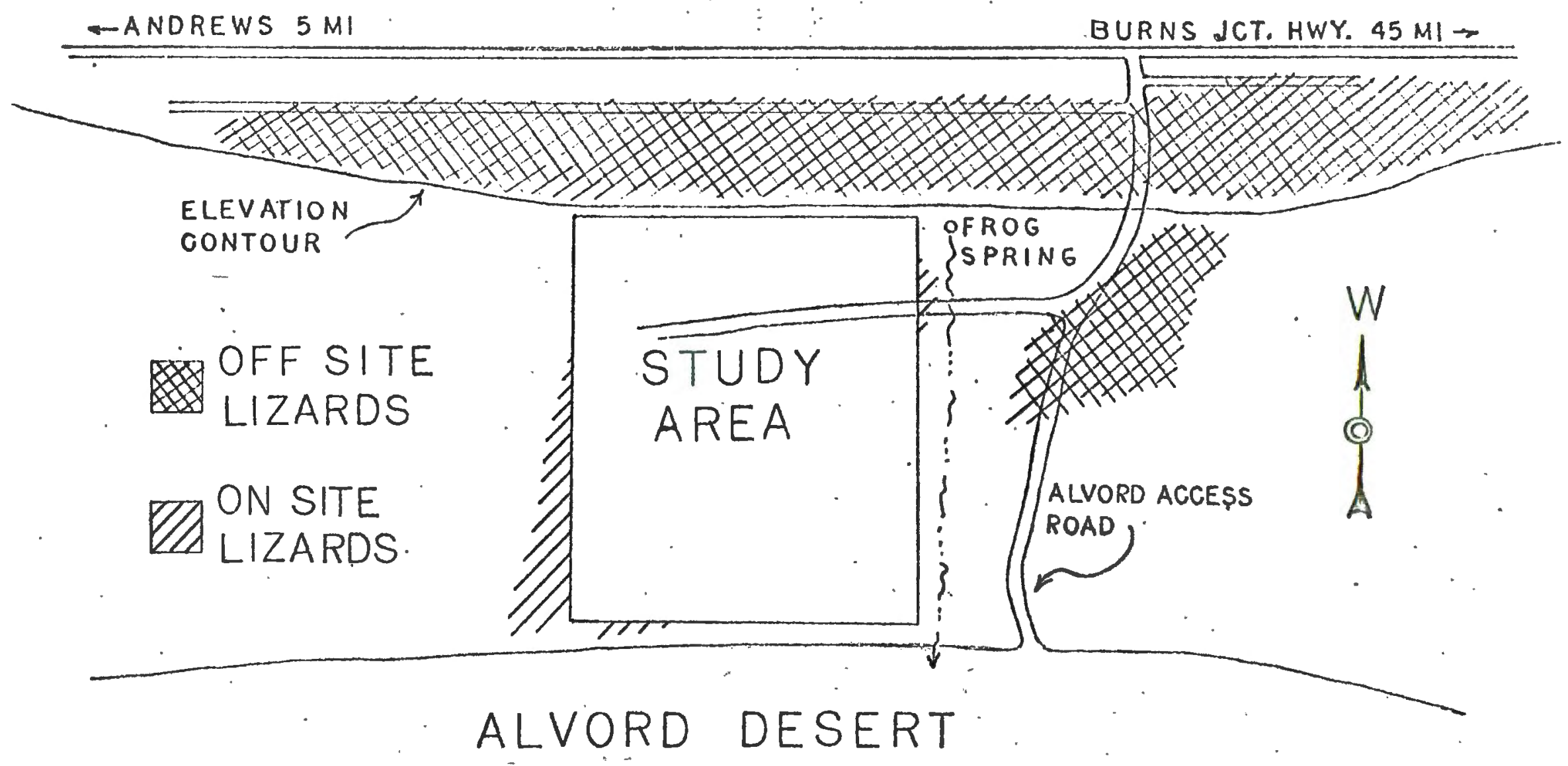

Figure 23. Off-site activity of Gambelia wislizeni up to 200 meters. 
were directed toward the sites periphery, primary area including the west and north boundaries. Due south and east were depicted on circular diagrams respectively at 180 and $270^{\circ}$. Most moves of juveniles occurred between $180^{\circ}$ and $360^{\circ}$. Mean directional movement in juveniles $\left(219^{\circ}\right.$ ) was pretty close to the median $\left(225^{\circ}\right)$ between north and south. Thus mean juvenile movement, in a near southeast direction, is probably a combination of migration of individuals from west and north perimeters toward the site's center. The widely spread moves on the circular diagrams for adult female and adult male G. wislizeni do not indicate a directional pattern. Therefore, not showing a postreproductive migration, adult females must return to their respective home ranges immediately after egg laying. 


\section{DISCUSSION}

Thermal Ecology

Reptiles have classically been described as poikilothermic (having extremely variable body temperatures). Lizards do not follow the strictest definition of poikilotherm. TB is regulated through several behavioral methods. For some, $T_{B}$ is regulated in part by physiological processes, too.

The terminology followed here is that of Cowles (1962). Primarily, lizards are ectotherms depending upon external (environmental) sources of heat to regulate $\mathrm{T}_{\mathrm{B}}$. Ectotherms may derive their heat either by basking or through conduction from the environment. The term heliotherm is used to describe ectotherms which rely on periodic basking for their thermoregulation. In contrast, thigmotherms are those ectotherms which derive their heat primarily by conduction from the medium in which they live, whether air, water, or soil. Both heliothermic and thigmothermic lizards often coexist at a given locality. Most lizards, especially diurnal forms, while being primarily one type of ectotherm, usually employ behavior representative of both types (Soule, 1963; Brattstrom, 1965). G. wislizeni, in the Alvord Basin region, function as heliotherms much of the time, but may display considerable thigmothermic behavior during morning basking, throughout the day when prevailing weather conditions are cool and in late afternoon on warm days. This kind of behavior was 
also observed in other lizards inhabiting the area, e.g., Phrynosoma platyrhinos and Cnemidophorus tigris.

Generally speaking, methods employed by G. wislizeni to regulate $T_{B}$ are not unique, and positions and postures associated with basking, exploratory movement, perching, shade-seeking and burrowing have all been previously implicated in lizard thermoregulation (Cole, 1943; Cowles and Bogert, 1944; Bogert, 1949; Norris, 1953; Pearson, 1954; Fitch, 1956; Inger, 1959; Carpenter, 1961; Johnson, 1965; 'Heatwole, 1970; Pough, 1970; Brattstrom, 1971; and Judd, 1975). Bakkar (1975) has extracted enough quantitative metabolic information from the fossil record to implicate that the dinosaurs were largely endothermic. Modern day lizards are hardly able to regulate $T_{B}$ with the constancy found in endotherms. However, it has been discovered that some lizards and other reptiles, especially the larger ones, show some features indicative of endothermy by exerting a certain amount of physiological control over $\mathrm{T}_{B}$ or pattern of heat distribution, or both, within the body through cardiovascular adjustments (Cowles, 1958; Bartholomew and Tucker, 1963; and Heath, 1966); endogenous heat production (Bartholomew and Tucker, 1964), and muscular activity (Cole, 1943). Bartholomew and Tucker (1963) and Lashbrook (1970) postulated that such thermoregulatory mechanisms must be concerned with a control of rates of change in $T_{B}$, and that this must be accomplished before the maintenance of 
constant $\mathrm{T}_{\dot{B}}$ by endothermism can evolve. These aspects were not investigated in G. wislizeni, but arc probably of relatively insignificant importance because of the species' small size. With the possible exception of metachromatism (Soule, 1963) and evaporative cooling (Templeton, 1960; Daws on and Templeton, 1963), strictly physiological thermoregulation probably serves only an auxillary role in $G$. wistizeni.

As an ectotherm, G. wislizeni depends a great deal on environmental sources of heat, to regulate $\mathrm{T}_{B}$. The species loses or gains heat in the following manner: radiation from insolation, radiation to or from other objects (surrounding vegetation, sand, and atmosphere); conduction to or from the substratum; and convection to or from the air. The amount of heat exchanged with the environment depends upon the surface area of the lizard exposed; the temperature difference between the medium (air or substrate) and the lizard's surface; and the conductive properties of the medium (Bartlett and Gates, 1967).

In the present study, the effect of certain environmental temperatures (TASH, $T_{S S N}$, and $T_{S S H}$ ) on $T_{B}$ were investigated. Multiple regression analysis revealed that $\mathrm{T}_{\mathrm{ASH}}$ has little effect on the $\mathrm{T}_{\mathrm{B}}$ of $\mathrm{G}$. wislizeni. Cole (1943) arrived at a similar conclusion for several other species of North American lizards. Air is a poor conductor of heat. Consequently, most of the range of TASH 
present during lizard activity contributes little to $\mathrm{T}_{B}$ regulation. However, it is probable that $\mathrm{T}_{\mathrm{ASH}}$ has considerable effect on $T_{B}$ at its extremes. Dewitt (1967) noticed that $\mathrm{T}_{\mathrm{B}}$ of Dipsosaurus dorsalis recorded in a the rmal gradient were essentially indepondent of minimum available air temperature between 34 and $39^{\circ} \mathrm{C}$. However, when these minimum temperatures exceeded $39^{\circ} \mathrm{C}, \mathrm{T}_{\mathrm{B}}$ showed dependence, being about $1.2^{\circ} \mathrm{C}$ above the corresponding minimum available air temperatures. Considering $\mathrm{T}_{\mathrm{ASH}}$ as the minimum available air temperature, at $T_{\text {ASH }}$ of about $40^{\circ} \mathrm{C}$ active G. wislizeni were almost non-existent. Apparently, the poor conductivity of air makes it difficult to dissi-. pate heat buildup from other environmental sources.

The exchange of heat between the body surface and air is highly dependent upon the velocity of the circulating air; the greater the velocity, the greater the heat exchange.. Prevailing weather conditions in the Alvord Basin frequently included persistent, gusty winds. On both warm and cool days, strong winds reduced the activity of $G$. wislizeni. Under such conditions, most of the individuals sighted were sitting on the leeward side of shrubs. On. cool days they positioned themselves to receive maximum solar radiation and conduction from the sand, but remained protected from the main force of the wind.by staying close. to overhanging limbs and other vegetation. When wind gusts were most intense, very little movement was observed. At 
this time, $\mathrm{T}_{\mathrm{ASH}}$ probably produced considerable effect on $\mathrm{T}_{\mathrm{B}} \cdot$

The sand surface is a better environmental source of heat transfer than air. Multiple regression analysis showed TSSN and TSSH to affect significantly $T_{B}$ of $G$. wislizeni. The fact that this species exhibited considerable thigmothermic behavior throughout much of the day, expecially when weather was unseasonally cool or overcast, makes these findings clear.

It was difficult to measure the effect of solar radiation and radiation from other objects so I did not do it. Undoubtedly solar radiation contributes a great deal to regulation of $\mathrm{T}_{\mathrm{B}}$. Pearson (1954) found another lizard. species attaining a $\mathrm{T}_{\mathrm{B}}$ of $31^{\circ} \mathrm{C}$ when $\mathrm{T}_{\mathrm{ASH}}$ registered $0^{\circ} \mathrm{C}$, a difference of $31^{\circ} \mathrm{C}$ ! He noted that this large temperature difference was partially due to heat gain from the substratum, but did not list temperatures for the source. In the Alvord Basin, emerging G. wislizeni frequently attained $\mathrm{T}_{\mathrm{B}}$ considerably higher than TASH. TSSN, at the times when $\mathrm{T}_{\mathrm{B}}$ and $\mathrm{T}_{\mathrm{ASH}}$ differed the most, varied with the weather. During early morning basking, TSSN averaged $2-3^{\circ} \mathrm{C}$ below $\mathrm{T}_{\mathrm{B}}$. However, the little data gathered for early morning activity under unseasonally cool conditions best displayed G. wislizeni's heliothermic ability; $\mathrm{T}_{\mathrm{B}}$ at this time averaged 5 to $10^{\circ} \mathrm{C}$ above TSSN. Because of sparse vegetation, and presence of only a few rocks, radiation from other objects 
was largely from the sand surface. This source is probably most influential on $T_{B}$ during periods of maximum solar intensity. It seems likely that solar radiation (primarily) and radiation from other objects (secondarily) contribute much to the unexplained portion of the multiple regression correlation coefficient (Table III).

All of the environmental heat sources probably have an effect on $T_{B}$. Soule (1963) reported that the relative contributions of heat sources are a function of the behavior and ecology of the lizard, species being examined. Considering the environmental temperatures recorded while studying $G$. wislizeni, the substrate temperatures affected $T_{B}$ more than air temperatures; but exceptions occurred during periods of unseasonably cool and warm weather and/or windy conditions.

Assessment of the temperature levels important to $G$. wistizeni involves the use of terminology adopted by Cowles and Bogert (1944). Voluntary minimum is the lowest $T_{B}$ tolerated; voluntary maximum is the highest $\mathrm{T}_{\mathrm{B}}$ tolerated. When $T_{B}$ extends outside these limits, lizards usually retreat. to underground burrows. In the case of voluntary maximum, retreat to deep shade serves the same purpose as a burrow. Basking range begins with $\mathrm{T}_{\mathrm{B}}$ at voluntary minimum and extends to the thermal point where the drive to bask is replaced by ordinary routine activity. Normal activity range represents the $T_{B}$ at which routine activity is con- 
ducted. The mean $T_{B}$ of this range is referred to as the ecological optimum.

The elucidation of the $T_{B}$ range at which $G$. wislizeni bask and undertake routine activity is a difficult task. As is true in other lizard species (Lee and Badham, 1963), G. wislizeni is an opportunistic basker, heating to the highest $\mathrm{T}_{\mathrm{B}}$ (close to the point of maximum voluntary tolerance) that environmental conditions permit. In the field many basking individuals registered $T_{B}$ of 38 to $40^{\circ} \mathrm{C}$. This enables the species to store the maximum amount of heat practical without reaching physiologically damaging temperatures and therefore maintain higher $T_{B}$ longer when environmental conditions favor heat loss. However, environmentai conditions were often unseasonably cool, and kept G. wislizeni from heating to $\mathrm{T}_{\mathrm{B}}$ near maximum voluntary tolerance. On several occasions, prevailing cool conditions probably allowed $T_{B}$ just barely to reach the lower limit of the normal activity range. For these individuals, little heat could be stored at one time and they were forced into repeated and prolonged periods of basking. From field data, all lizards registering $\mathrm{T}_{\mathrm{B}}$ below the 28 to $30^{\circ} \mathrm{C}$ range seemed to fit this category. G. wislizeni involved in exploratory movements, feeding, and reproduction were considered to be maintaining $\mathrm{T}_{\mathrm{B}}$ in the normal activity range, such behavior only occurred at $\mathrm{T}_{B}$ between upper 20 's and lower $40^{\prime} \mathrm{s}{ }^{\circ} \mathrm{C}$. It is obvious. that $\mathrm{T}_{B}$ in the normal acti- 
vity range varies according to the prevailing thermal conditions in the environment. Consequently, the mean value for one group of temperatures falling in the normal activity range may deviate considerably from the mean value of another group. This brings about inconsistency when interpreting the mean as the ecological optimum. If such a temperature level exists, another method is required for its elucidation. For now, all that can be said about normal activity range is that it represents $T_{B}$ permitting routine activity.

Some studies have stressed that within a species, under favorable thermal conditions, there is a high degree of constancy of $\mathrm{T}_{\mathrm{B}}$ among active individuals, or have pointa. ed out that species in a given genus have remarkably similar mean $T_{B}$ despite differences in hảbitat, altitude, and geographic locality (Bogert, 1949; and Hirth, 1964). Others have shown greater variation with mean $\mathrm{T}_{B}$ changing with geographic area (compare Hirth, 1963 with McGinnis and Brown, 1966), elevation (Brattstrom, 1965, and Mueller, 1969), weather conditions (Packard and Packard, 1970), time of day (Ruibal, 1961), from day to day (Warburg, 1965), and seas on (Mayhew, 1963; McGinnis, 1966; Ballinger, Hawker, and Sexton, 1969; Ballinger et al., 1970). Studies on G. wislizeni appear to support the conclusion that mean $\mathrm{T}_{\mathrm{B}}$ does not vary. geographically, or temporally. During the summers of 1974 and 1975,168 field $T_{B}$ 
were recorded on clear days. It is interesting to note the similarity between these values and those obtained during October, 1975 in a thermal gradient. The MPT determined in the thermal gradient $\left(37.09^{\circ} \mathrm{C}, \mathrm{S} . \mathrm{D} .=2.3\right)$ is remarkably close to the mean $T_{B}$ calculated for field data $(37.14$, S.D. $=3.7)$. Consequently, these means differ insignificantly $(t=0.1094, P>.50)$. The results of the present study are in agreement with those of Parker and Pianka (1976) who found similar mean ${ }^{\circ} \mathrm{B}$ for both northern $\left(37.34^{\circ} \mathrm{C}\right)$ and southern $\left(37.39^{\circ} \mathrm{C}\right)$ populations of G. wislizeni. The above mean $\mathrm{T}_{B}$ are somewhat lower than values obtained by Cowles and Bogert $\left(1944-38.7^{\circ} \mathrm{C}\right.$ ), Brattstrom (1965 $\left.38.3^{\circ} \mathrm{C}\right)$, and Tanner and Krough $\left(1974-38.5^{\circ} \mathrm{C}\right)$. These values, taken in southern California and Nevada, probably reflect a bias due to small sample size. Perhaps similarity between mean $\mathrm{T}_{B}$ of Parker and Pianka and the present study better indicates the ecological optimum.

G. wislizeni achieve maximum $\mathrm{T}_{\mathrm{B}}$ values quite early in the morning. The change in mean $\mathrm{T}_{\mathrm{B}}$ during the course of a day is interpreted as being largely due to rising minimum values with warming environmental conditions. Consequently, mean $\mathrm{T}_{B}$ at different times of the day, under consistently favorable conditions, does not appear to vary. Seasonal variation in mean $\mathrm{T}_{B}$ was not investigated, but comparison of a few values taken in May, 1976 (not part of the present study) with combined values for both summers, show differ- 
ences to be slight.

The overall mean $T_{B}$ of $G$. wislizeni, based on 283 field values, is considerably lower than those mentioned above. Undoubtedly, prevailing thermal conditions are responsible for the difference. In the American southwest, where most of the other $\mathrm{T}_{\mathrm{B}}$ of $G$. wiszizeni have been recorded, weather conditons are generally warm and fluctuate with seasonal regularity. Weather conditions on the Alvord Basin fluctuate daily as well as seasonally, and can be unseasonally cool any time during the active portion of the species seasonal periodicity. Therefore, it would appear that while warm temperatures occasionally limit activity in southern lizards, cool temperatures may do the same for northern lizards. Dewitt et al. (1967) noted that in order to extend the activity period long enough to perform necessary tasks, the desert ignuana abandons preferred body temperatures and conforms to the coolest available environmental conditions. G. wislizeni on the Alvord Basin is only infrequently faced with extreme warm conditions, but must make some adjustment for frequently cool conditions. When weather is unseasonally cool lizards choosing to remain active are forced to abandon PBI and accept tho warmost aviliablo cnvironmontal conditions. Cowles and Bogert (1944) noted that G. wislizeni invariably retreated when air temperature lowered to $23^{\circ} \mathrm{C}$. Lizards on the Alvord Basin remain highly active at this temperature. Dwitt (1967) remarked that at times, thermal conditions may be insufficient to permit $\mathrm{T}_{B}$ to rise 
to preferred levels, and at other times they may be insufficient to permit $T_{B}$ to rise to preferred levels, and at other times they may be insufficient to permit $T_{B}$ below this level. In the present study, the former is primarily true. The issue of routine activity at a great number of $\mathrm{T}_{B}$ (normal activity range) as opposed to a selected few $\mathrm{T}_{\mathrm{B}}$ (ecological optimum or preferred temperature) has generated considerable recent interest. It appears that such relationships are highly variable in lizard species (Brattstrom 1965). G. wislizeni appears to have a preferred $\mathrm{T}_{\mathrm{B}} \mathrm{range}$, but is adapted to undertake routine activity outside of this this range. The direct effect of thermal conditions on mean $\mathrm{T}_{\mathrm{B}}$ has already been discussed. In addition, mean $\mathrm{T}_{\mathrm{B}}$ may be influenced by factors affecting preferred temperatures such as acclimation, intraspecific genetic differences, and differences in preferred temperatures for diffierent activities. Heatwole (1970) states "these are not mutually exclusive either among themselves or with respect to direct environmental limitations."

The effect of acclimation on preferred body temperature shows considerable interspecific variation (Wilhoft and Anderson, 1960; McGinnis, 1968; Light, 1968; Ballinger et ar. 1969; and Mueller, 1969). In the case of G. wislizeni, unless acclimation proceeds with extreme rapidity, it cannot account for large, short-term shifts in mean $\mathrm{T}_{B}$ in a given locality such as occurs on the Alvord Basin. 
Soule (1963) postulated that acclimation is an exogenously induced phenotypic alteration which apprently is affected by raising or lowcring the optima and ranges of thermochemical processes. It seems alterations of this nature, taking sometime to develop, require a general consistency of changing environmental conditions. Probably photoperiod and average temperatures throughout the course of a season are primarily responsible for a shift in $\mathrm{T}_{B}$. I doubt if acclimation accounts for any large, short-term shift in mean $\mathrm{T}_{\mathrm{B}}$ of G. wislizeni at a given locality. Geographically, some acclimation may result in differences in ranges of $T_{B}$ acceptable for activity. Probably the upper limit of the range is similar regardless of geographic loçation, but as stated above there is some evidence that the lower limits differ. Based on comparisons of $\mathrm{T}_{B}$ under favorable conditions, differences in thermal optima for thermochemical processes seemingly change very little geographically. The importance of intraspecific genetic differences in thermoregulation remains to be adequately investigated. G. wislizeni, times of activity and exposure to immediate environmental conditions are basically similar for all individuals. Therefore, genetic differences would not ex-'. plain short-term variations in mean $T_{B}$ for individuals at a. given locality. Slight geographic variations probably are without genetic basis.

When discussing preferred temperatures for different 
activities it is important to clearly distinguish between thermoregulatory and non-thermoregulatory behavior. In as much as thermoregulatory behaviors are means of achieving particular preferred body temperatures, they tend to be temperature specific (Heath, 1965). For example, basking behavior is elicited primarily at $T_{B}$ below the range of normal activity, and shade-seeking at those above it. In G. wislizeni similar environmental conditions (solar intensity and temperatures) will bring about a characteristic behavior pattern, regardless of the time of day. However, it must be emphasized that G. wislizeni demonstrates some flexibility in the thermoregulatory responses. Alternate behavior patterns serving the same function occur; e.g., burrowing and shade seeking are interchangeable, and in certain situations thermal exchange with the substrate may be employed instead of heliothermic basking.

Non-thermoregulatory behavior may be temperature specific for at least a few activities in some species (Regal, 1966). However, thermal compartmentalization of activities probably does not include certain essential behavior patterns (Lee and Badham, 1963). Shifts in preferred temperature may occur in response to such changes in physical conditon as molting, injury, or parasitism (Kitchel1, 1969). Finally, some species appear to be without $\mathrm{T}_{\mathrm{B}}$ preference for all activities (Ballinger et al., 1970). Apparently, G. wislizeni lacks thermal comparmenta- 
lization. Based on field data, exploratory movement occurred at $\mathrm{T}_{B}$ ranging between upper $20^{\prime} \mathrm{s}$ and lower $40^{\prime} \mathrm{s}{ }^{\circ} \mathrm{C}$. Ficld observations show a similar range for feeding. In captivity, one individual at a $\mathrm{TB}_{\mathrm{B}}$ of $25.4^{\circ} \mathrm{C}$ took a mealworm, and on several occasions individuals were observed feeding under environmental conditions which would not allow attainment of the normal activity range.' Defecation was nover observed in the field, but occurred in captivity at T $T_{B}$ ranging between 21.0 and $41.0^{\circ} \mathrm{C}$. Unfortunately, in only one incidence of copulation were $\mathrm{T}_{\mathrm{B}}$ recorded. For male and female $\mathrm{T}_{\mathrm{B}}$ were respectively $38.4^{\circ} \mathrm{C}$ and $36.5^{\circ} \mathrm{C}$. Since most mating behavior occurs in May and June, a time period when thermal conditions are often cool, it seems that reproductive success would depend upon flexible $T_{B}$.

The following remarks are based on the work of Burt (1943). Home range is an area traversed by the individual in its normal activities such as food procurement and mating. Home range size may vary with sex, age, season, and population density. Home ranges of different individuals may, and do, overlap; often a portion or the entire home range is protected by an individual from intruders (territoriality). When determining home range size it must be remembered that (1) occasional sallies outside the area, perhaps exploratory in nature, should not be considered as a part of the home range, (2) home ranges are rarely, if ever, convenient geometric designs (many are probably 
ameboid in outline), and (3) often individuals move from one area to another, therby abandoning an old home range and setting up a new one. Burt formed these concepts while studying small mammals. However, they also apply to many reptiles, including.G. wislizeni. Numerous methods have been enployed to determine home ranges of lizards (Fitch, 1954; Tinkle, 1962; Jorgenson and Tanner, 1963; Johnson, 1965; Jennrich and Turner, 1969; and Turner et al., 1969). However, none of these unveils a complete account of the area occupied by an individual, (Turner, 1971).'

I evaluated the movement of G. wislizeni using convex polygons (Barwick, 1959; Tịnkle, 1962; Bostic, 1965; Brooks, 1967; and Stebbins et al., 1967).

The home range size of G. wislizeni is relatively substantial. Tanner (1974) noted that areas occupied by the species tended to be larger than those for other 1izard species he had studied. I know of no other study of home range size differences between sexes and age in $G$. wislizeni. The fact that average home range size of adult males is considerably larger than that of adult females is not unique, since this situation is known to occur in several other lizard species (Fitch, 1954; and ]958; Blair, 1960; Tinkle et al., 1962; Hirth, 1963; and Brooks, 1967). These studies report variable home range size relationships between adults and juveniles, and juvenile males and females. However, adult males always occupy an average area 
larger than do juveniles. The average area occupied by juvenile males often is larger than the average area occuplied by juvenile females.' 'In some species, juveniles of one or both sexes occupy an average area equal to or exceeding the average area for adult females. The following comparisons are based on identical numbers of captures. In G. wislizeni, average adult male home range area is considerably larger than for either juvenile sex. For the limited records available juvenile males and females appear to occupy similar average areas. Blair (1960) found that the home range size for juvenile sceloporus olivaceous increased as the individuals grew. This is also true of $G$. wislizeni. Upon reaching sexual maturity, both sexes continue to show an increase in home range size, but the rate is far more gradual in females. Based on the limited movement of some adult females, perhaps home range size varies little after reaching sexual maturity. Even with continued growth, in which adult females profoundly exceed adult males (Figure 24), the latter still occupies a larger area. I was unable to observe movement in G. wislizeni during early portions of seasonal periodicity. The extent of movement in the species during the time of mating is not known. Comparison of home range data for early and midsummer shows that the area occupied by adult males declines as the summer passes. For these two periods female home range size remains the same or slightly expands. This 


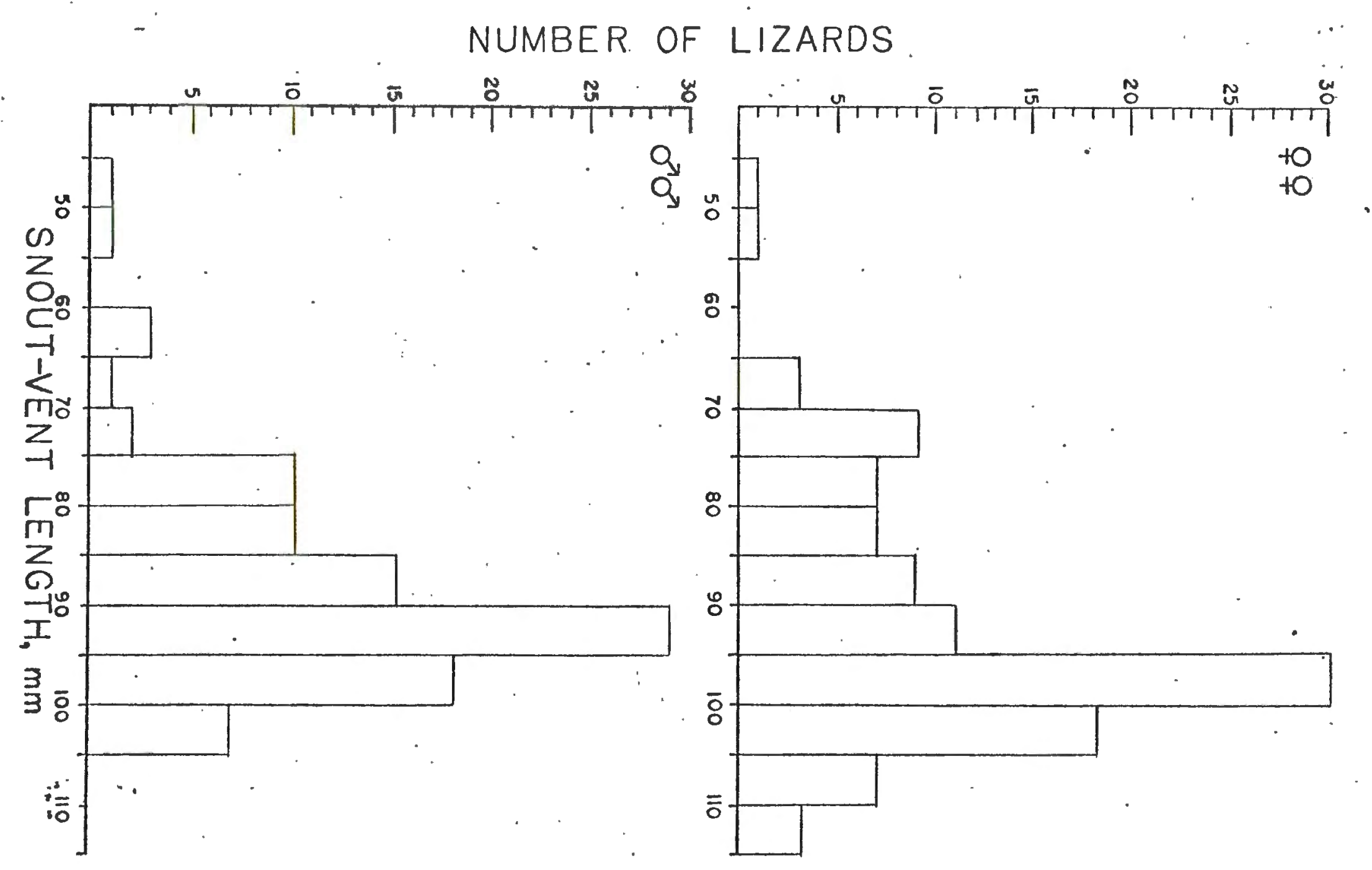

Figure 24. Frequency distribution of 203 measurements of snout-vent length G. wislizeni. 
behavior in both sexes is probably related to the stored fat requirements mentioned above. The population density of $G$. wislizeni at Frog Spring during the two years of study remained about the same for adults. In 1974 no juveniles were observed on the site. However, the presence of juveniles in 1975 did not seem to affect the home range size of adults. Territoriality has been described in many lizard species (see Carpenter, 1967). The issue of territoriality in Gambetia has been frequently discussed. Intraspecific display or aggression has yet to be verified in G. wislizeni (Carpenter, 1967; McCoy, 1967), but appears to be definite in G. silus (Montanucci, 1965, 1969, and 1970). G. wislizeni in the Alvord Basin demonstrated very little intraspecific aggression or display. Aggression between adult males dur ing the mating season was not observed during brief visits in May of 1975 and 1976. On two occasions adult males and females were observed chasing juveniles. The fact that all but one juvenile home range was located near the site's periphery may suggest territoriality.

The configuration and position of one home range with respect to others may be evidence of territoriality. Tanner and Krogh (1974) noted that plotted polygons for the species tend to be elongate; the same applies to the plotted polygons in the present study. Perhaps the arrangement allows for maximum area occupied with minimum overlap. Adult males, having the least home range elongation, show considerable 
overlap. Some juvenile home ranges have reduced elongation. However, small size limits the extent of overlap between juveniles. In addition to small size, location limits overlap between adults and juveniles. Adult female home ranges are often quite elongate. Overlap between adult females is the least of all groups. Overlap of adult females and juveniles is minimized by home range location of the latter. Adult female and male home range overlap is extensive, but is probably permissible because of the males' occupancy of a much larger average area.

Tanner and Krogh (1974) remarked that due to predatory habits, home range size in G. wislizeni may not be as'stable as in some other species, and that there is some shifting of the ranges and some nomadic behavior. Because of the relatively short time period and natural barriers surrounding the site, the present study is unable to clarify this issue. A visit to the site in May of 1976 (not part of the present study) revealed all individuals but one (an unmarked juvenile of the previous year) were within the areas occupied during the previous two seasons. One female was within 30 meters of her first sighting in 1974. Based on two seasons of data, it is quite possible adult males will occupy most of the site within a lifetime. Some shifting of home ranges for adult females was noted, but surprisingly most maintained a similar range for both seasons. The fact that lizards on the site never ventured far beyond the periphery 
probably indicates the efficiency of the natural barriers. It would be interesting to examine the stability of home ranges occurring where the terrain is more homogeneous. Because of their infrequent activity, home range size may not be a valid indicator of movement in adult female $G$. wislizeni. Continuous observations may be a more worthwhile method. In the distance traveled per hour method, adult males greatly exceed adult females in average distance traveled per hour, the latter traveling an average distance similar to that calculated for juveniles. The fact that some males travel over 100 meters in an hour is truly remarkable. More or less, much of the distance covered is of a wide angled zig-zag pattern, and it is conceivable that in less than the course of a day an individual may move the width of the site. However, because frequently sighted males usually occupied an area much smaller than the area of the study site it is probable that these individuals eventually change direction, or cease to move. It must be remembered that prevailing weather conditions and diel activity patterns control the extent of movement. During seasonal weather dicl activity is bimodal. Based on hourly observations, lizards move the greatest distances immediately after basking and during mid-afternoon. Least distances are covered in late morning and early afternoon. Therefore, it seems the extent of movement in the individuals covering the greatest distances would decline shortly 
after the hour of observation. Continuous observation for longer periods of time should provide some conclusive results. Adult females and juveniles also move in the same characteristic zig-zag manner.

Comparison of average area added for each new sighting, and average distance traveled per hour, show interesting similarities, and together probably indicate a reliable account of the extent of movement in the species. Interpretation of these two estimates of movement, coupled with some consistent observations seems to indicate the following relationships. Adult males, showing considerable movement, home range overlap, and lack of intraspecific display and aggression among themselves, probably lack a definite home range. Adult females, showing limited movement, and less home range overlap, may possess a definite home range. Additional support for this idea may come from the females' long individual moves, and their posnuptial orange coloration. The fact that females longest moves are similar to those of adult males indicates the capability of adult females to cover considerable area, but possibly due to some intcrmal regulating mechanism, the area covered remains much less. Perhaps postnuptial orange coloration, serving as a warning to other adult females, assures space for all individuals for successful egg laying. Juveniles, showing frequent, but short movement, little home range overlap with adults, and being the source of some form of adult aggression, 
are probably dispersing on the site in a gradual manner. Movement in G. wislizeni is probably independent of environmental thermal conditions when $\mathrm{T}_{B}$ is within limits of the normal activity range. Such a situation is highly beneficial in that it allows for extended periods during which routine activity can also occur. All $\mathrm{T}_{\mathrm{B}}$ recorded at the end of an hour of observation were well within the normal activity range, even though environmental temperatures were quite variable. This shows the species' remarkable ability to thermoregulate. Nonetheless, on some occasions (apart from hourly obsorvations) individuals captured after traveling a considerable distance had $\mathrm{T}_{\mathrm{B}}$ approaching or within the range of maximum voluntary tolerance. Apparently, some physiological conditions may permit some movement to occur at $T_{B}$ outside the normal activity range. In addition, such exposure may be the result of an attempt to escape thermal stress or predation. However, to avoid overheating, these instances are of brief duration.

I know of no other attempt to predict directional movement in lizards. Based on angles plotted on a circle, directional movement from day to day appears to be random. However, during the course of the season the re may be some order to the movement. It was already pointed out that adult males and juveniles may lack a definable home range. It would appear both groups have no preference for particular areas over which they move. In other words, select 
basking sites, feeding sites, and burrows are relatively unimportant. Though adult females may have a definable home range, movement within the area appears to be almost as random as that of adult males. Consequently, adult females have no preference for specific localities either. Seasonal order in movement for adults is questionable. However, it seems likely that juvenile movement is directional. 


\section{LITERATURE CITED}

Atsatt, S. R. 1939. Color changes as controlled by temperature and light in the lizards of the desert regions of southern California. Publ. Univ. California, Los Angeles, Biol. Sci. 1:237-276.

Baird, S. F., and C. Girard. 1852. Reptiles (pp. 336$365,8 \mathrm{p} 1 \mathrm{~s}$ ) In Howard Stansbury, Exploration and Survey of the Valley of the Great Salt Lake of Utah. Philadelphia, Lippincott, Grambo \& Co. $487 \mathrm{p}$.

- 1858. Description of New General and Species of North American lizards in the Museum of the Smithsonian Institution. Proc. Acad. Nat. Sci. Philadelphia, 10:253-256.

Bakker, R. T. 1975. Dinosaur Renaissance. Sci. Amer. 232(4): 52-78.

Baldwin, E. M. 1964. Geology of Oregon. Univ. Oregon, Eugene. $165 \mathrm{p}$.

Ballinger, R. E., J. Hawker, and O. J. Sexton. 1969. The effect of photoperiod acclimation on the thermal regulation of the lizard, Sceloporus undulatus. J. Exp. Zoo1. 171:43-48.

Ballinger, R. E., K. R. Marion, and O. J. Sexton. 1970. Thermal ecology of the lizard Anolis limifrons with comparative notes on three aditional Panamanian anoles.. Ecology 51:246-254.

Ballinger, R. E., and G. D. Schrank. 1970. Acclimation rate and variability on the critical thermal maximum in the lizard, Phrynosoma cornutum. Physiol. Zool. $43: 19-22$.

Banta, B. H., and W. W. Tanner. 1968. The systematics of Crotaphytus wislizeni, he leopard lizards (Sauria: Iguanidae). Part II. A review of the status of the Baja California peninsular populations and a description of a new subspecies from Cedros Island. Great Basin Nat. 23:183-194.

Bartholomew, G. A., and V. A. Tucker. 1963. Control of changes in body temperature, metabolism, and circulation by the agamid lizard, Amphibolurus barbatus. Physiol. Zool. 36: 199-218. 
Bartholomew, G. A. and V. A. Tucker. 1964. Size, body temperature, thermal conductance, oxygen consumption, and heart rate in Australian varanid lizards. Physiol. 2001. 37:341-354.

Bartlett, P. N. and D. M. Gates. 1967. The energy budget of a lizard on a tree trunk. Ecology 48:315-322.

Barwick, R. E. 1959. The life history of the common New Zealand skink Leiolopisma zelandica (Gray 1843).

Trans. R. Soc. N. Z. 86:331-380.

Blair, W. F. 1960. The Rusty Lizard - a population study. Univ. Texas Press: Austin, $185 \mathrm{p}$.

Bogert, C. M. 1949. Thermoregulation in reptiles, a factor in evolution. Evolution 3:195-211.

Bogert, C. M. 1959. How reptiles regulate their body temperature. Sci. Amer. 200:105-120.

Bostic, D. L. 1965. Home range of the teiid lizard, Cnemidophorus hyperythrus beldingi. Southwest Natur. 10:278-281.

Brattstrom, B. H. 1953. Records of Pleistocene reptiles from California. Copeia 1953:174-179.

Brattstrom, B. H. 1965. Body temperature of reptiles. Am. Midl. Nat. 73:376-422.

Brattstrom, B. H. 1971. Social and thermoregulatory behavior of the bearded dragon Amphibolurus barbatus. Copeia 1971:484-496.

Brookings, W. J. 1934. Some reptiles and amphibians from Malheur County in eastern Oregon. Copeia 1934:93-95.

Brooks, G. R., Jr. 1967. Population ecology of the ground skink, Lygosoma ZateraZe (Say). Ecol. Monogr.' 37 : $71-87$.

Burt, W. H. 1943. Territoriality and home range concepts as applied to mammals. J. Mammalogy 24:346-352.

Carpenter, C. C. 1956. Body temperatures of three species of Thamnophis. Ecology 37:732-735.

Carpenter, C. C. 1961. Temperature relationships of two Oklahoma lizards. Proc. Okla. Acad. Sci, 41:72-77. 
Carpenter, C. C. 1967. Aggression and social structure in iguanid lizards. 'In "Lizard Ecology: a Symposium (W. W. Milstead, ed.) pp. 87-105 Univ. Missouri Press, Columbia".

Cole, L. C. 1943. Experiments on toleration of high temperature in lizards with reference to adaptive coloration. Ecology 24:94-108.

Cowles, R. B. 1940. Additional implication of reptilian sensitivity to high temperatures. Amer. Nat. 74: $542-561$.

Cowles, R. B. 1958. Possible origin of dermal temperature regulation. Evolution 12:347-357.

Cowles, R. B. 1962. Semantics in biothermal studies. Science 135:670.

Cowles, R. B. and C. M. Bogert. 1944. A preliminary study of the thermal requirements of desert reptiles. Bull. Amer. Mus. Nat. Hist. 83:265-296.

Cunningham, J. D. 1966. Additional observations on the body temperatures of reptiles (snakes and lizards). Herpetologica 22:184-189.

DeWitt, C. B. 1967. Precision thermoregulation and its relation to environmental factors in the desert iguana, Dipsosaurus dorsalis. Physiol. Z001. 40: 49-66.

DeWitt, C. B., S.'M. McGinnis and L. L. Dickson. 1967. Behavioral thermoregulation in the desert iguana. Science 158:809-810.

Fautin, R. W. 1946. Biotic communities of the northern desert shrub biome in western Utah. Ecol. Monogr. $16: 251-310$.

Fitch, H. S. 1954. Life history and ecology of the fivelined skink, Eumeces fasciatus. Univ. Kansas Publ. Mus. Nat. Hist. 8:1-156.

Fitch, H. S. 1956. An ecological study of the collared lizard (Crotaphytus colzaris). Univ. Kansas Publ., Mus. Nat. Hist., 213-274.

Fitch, H. S. 1958. Natural history of the six-lined racerunner (Cnemidophorus sexineatus). Univ.

Kansas Pub1., Mus. Nat. Hist. 11:11-62. 
Fitch, H. S. 1970. Reproductive cycles in lizards and snakes. Misc. Pub1. Univ. Kansas Mus. Nat. Hist. $52: 1-247$.

Heath, J. E. 1962. Temperature-independent morning emergence in lizards of the genus Phrynosoma. Science 138:891-892.

Heath, J. E. 1965. Temperature regulation and diurnal activity in horned lizards. Univ. Calif. Pub. 2001. 64:97-136.

Heath, J. E. 1966. Venous shunts in the cephalic sinuses or horned 1izards. Physiol. Z001. 39:30-35.

Heatwole, H. 1970. Thermal ecology of the desert dragon, Amphibolurus inermis. Ecol. Monogr. 40:425-457.

Hirth, H. F. 1963. Some aspects of the natural history of Iguana iguana on a tropical strand. Ecology 44: 61] 3-615.

Hirth, H. F. 1964. Temperature preferences of five species of neotropical lizards. Herpetologica 20: 273-276.

Hutchins on, V. H. and J. L. Larimer. 1960. Reflectivity of the integuments of some lizards from different habitats. Ecology 41:199-209.

Inger, R. F. 1959. Temperature responses and ecological relationships of two Bornean lizards. Ecology 40: $127-136$.

Irwin, L. N. 1965. Diel activity and social interaction of the lizard, Uta stansburiana stejnegeri. Copeia $1965: 99-101$.

Jennrich, R. I. and F. B. Turner, 1969. Measurement of non-circular home range. J. Theoret. Biol. 22: $227-237$.

Johnson, S. R. 1965. An ecological study of the chuck:-: . walla, Sauromalus obesus Baird in the western Mojave Desert. Amer. Midl. Nat. 73:1-29.

Jorgensen, C. D. and W. W. Tanner. 1963. The application of the density probability function to determine the home range of Uta stansburiana stansburiana and Cnemidophorus tigris tigris. Herpetologica 19: $105-115$. 
Judd, F. W. 1975. Activity and thermal ecology of the Keeled earless lizard, Holbrookia propingua. Herpetologica $31: 137-150$.

Kitchell, J. F. 1969. Thermophilic and thermophobic response of snakes in a thermal gradient. Copeia $1969: 189-191$.

Knowlton, G. F. 1934. Distributional and food habit notes on Utah Iizards. Copeia 1934:10-14.

Knowlton, G. F. 1936. Food habits of kull Valley lizards. Copeia 1936:64-66.

Larson, M. W. 1961. The critical thermal maximum of the Iizard, Sceloporus occidentalis occidentalis (Baird and Girard). Herpetologica 17:113-122.

Lashbrook, M. K. and R. L. Livezey. 1970. Effects of photoperiod on heat tolerance in Sceloporus ocoidentalis occidentalis. Physiol. Zool. 43:38-46.

Lee, A. K. and J. A. Badham. 1963. Body temperature, activity, and behavior of the agamid lizard, Amphibolurus barbatus. Copeia 1963:387-394.

Licht, P. 1966: Heat resistance of some Australian lizards. Copeia 1966:162-169.

Licht, P. 1968. Responses of the thermal preferendum and heat resistance to thermal acclimation under different photoperiods in the lizard Anolis carolinensis. Amer. Midl. Nat. 79:149-158.

Licht, P., W. R. Dawson, V. H. Shoemaker, and H. R. Main. 966. Observations on the thermal relations of western Australian 1izards. Copeia 1966:97-110.

Linsdale, J. M. 1938. Environmental responses of vertebrates in the Great Basin. Am. Midl. Nat. 19:1-206.

Lowe, C. H., Jr. and V. J. Vance. 1955. Acclimation of the critical thermal maximum of the reptile Urosaurus ornatus. Science 122:73-74.

Mardia, K. V. 1972. Statistics of directional data. Acad. Press, N. Y. 357 p.

Mayhew, W. W. 1963. Temperature preference of Sceloporus orcutti. Herpetologica 18:218-233. 
McCoy, C. J., Jr. 1967. Natural history notes on Crotaphytus wislizeni (Reptilia:Iguanidae) in Colorado. Am. Midl. Nat. 77:138-147.

McGinnis, S. M. 1966. Sceloporus occidentalis: preferred body temperature of the western fence lizard. Science 152:1090-1091.

McGinnis, S. M. and C. W. Brown. 1966. Thermal behavior of the green iguana, Iguana iguana. Herpetologica $22: 189-199$.

Mendenha11, W. 1971. Introduction to probability and statistics, third ed. Duxbury Press, Belmont, California. $466 \mathrm{p}$.

Miller, A. H. and R. C. Stebbins. 1964. The lives of desert animals in Joshua Tree National Monument. Univ. California Press, Berkeley.

Milstead, W. W. and D. W. Tinkle. 1969. Interrelationships of feeding habits in a population of lizards in southwestern Texas. Am. Midi. Nat. 81:491-499.

Montanucci, R. R. 1965. Observations on the San Joaquin leopard lizard, Crotaphytus wislizeni silus Stejneger. Herpetologica 21:270-283.

Montanucci, R. R. 1967. Further notes on leopard lizards, Crotaphytus wislizeni. Herpetologica 23:119-126.

Montanucci, R. R. 1969. REmarks upon the CrotaphytusGambelia controversy (Sauria:Iguanidae).

Hcrpetologica 25:308-314.

Montanucci, R. R. 1970. Analysis and hybridization between Crotaphytus wislizeni and Crotaphytus silus (Sauria:Iguanidae) in California. Copeia 1970: $104-123$.

Montanucci, R. R., R. W. Axte11 and H. C. Dessauer. 1975. Evolutionary divergence among collared lizards (Crotaphytus), with comments on the status of Gamberia. Herpetologica 31:336-347.

Mosauer, W. 1936. The toleration of solar heat in desert reptiles. Ecology 17:56-66.

Mueller, C. F. 1969. Temperature and energy characteristics of the sagebrush lizard (sceloporus graciosus) in Yellowstone National Park. Copeia 1969:153-160. 
Norris, K. S. 1953. The ecology of the desert iguana, Dipsosaurus dorsalis. Ecology 34:265-287.

Norris, K. S. 1967. Color adaptation in desert reptiles and its thermal relationships. In "Lizard Ecology: a Symposium (W. W. Milstead ed.) pp. 162-229 Univ. Missouri Press, Columbia."

Norris, K. S. and C. H. Lowe. 1964. An analysis of background color matching in amphibians and reptiles. Ecology $45: 565-580$.

Packard, G. C. and M. J. Packard. 1970. Eccrítíc temperatures of zebra tailed lizards of the Mojave Desert. Herpetologica 26:168-172.

Parker, W. S. and E. R. Pianka. 1976. Ecological observations on the leopard lizard (Crotaphytus wislizeni) in different parts of its range. Herpetologica 32:95-114.

Pearson, O. P. 1954. Habits of teh lizard Liolaemus multiformis multiformis at high altitudes in southern Peru. Copeia 1954:111-116.

Pianka, E. R. and H, D. Pianka. 1970. The ecology of Moloch horridus (Lacertilia:Agamidae) in Western Australia. Copeia 1970:90-103.

Pianka, E. R. and W. S. Parker. 1972. Ecology of the iguanid lizard Callisaurus draconoides. Copeia 1972:493-508.

Porter, W. P. 1967. Solar radiation through the living body walls of vertebrates with emphasis on desert reptiles. Ecol. Monogr. 37:273-296.

Porter, W. P. and D. M. Gates. 1969. Thermodynamic equilibria of animals with environment. Ecol. Monogr. 39:227-244.

Pough, F. H. 1970. The burrowing ecology of the sand lizard, Uma notata. Copeia 1970:145-157.

Regal, P. J. 1966. Thermophilic response following feeding in certain reptiles. Copeia 1966:588-590.

Regal, P. J. 1967. Voluntary hypothermia in reptiles. Science 155:1551-1553. 
Richardson, C. H. 1915. Reptiles of northwestern Nevada and adjacent territory. Proc. U. S. Natl. Mus. 48: $403-435$.

Robison, W. G. and W. W. Tanner. 1962. A comparative study of the species of the genus Crotaphytus Holbrook (Iguanidae). Brigham Young University Sci. Bull. Biol. Ser., 21:1-31, p s. 1-12.

Ruibal, R. 1961. Thermal relationships of five species of tropical lizards. Evolution 15:98-111.

Savage, J. M. 1958. The iguanid lizard genera Urosaurus and $U t a$, with remarks on related groups. Zoologica $43: 41-54$.

Shaw, C. E. 1952. Notes on the eggs and young of some United States and Mexican lizards. I. Herpetologica $8: 71-79$.

Smith, H. M. 1946. Handbook of lizards. Comstock Publ. Co., I thaca, N. Y. 557 p.

Soule, M. 1963. Aspects of thermoregulation in nine species of lizards from Baja California. Copeia 1963:107-115.

Stebbins, R. C. 1954. Amphibians and reptiles of western North America. McGraw-Hill Book Co., N. Y. 279 p.

Stebbins, R. C., J. M. Lowenstein and N. W. Cohen. 1967. A field study of the lava lizard (Tropidurus albemariensis) in the Galapagos Islands. Ecology $48: 839-851$.

Stejneger, L. 1890. Annotated list of reptiles and batrachians collected by Dr. C. Hart Merriam and Vernon C. Bailey on the San Francisco Mountain Plateau and desert of the Little Colorado, Arizona, with descriptions of new species. N. Am. Fauna 3: 103-118.

Stewart, G. R. 1965. Thermal ecology of the garter snakes Thamnophis sirtalis concinnus (Hallowell) and Thamnophis ordinoides (Baird and Girard). Herpetologica 21:81-102. 
Tanner, W. W., and B. H: Banta. 1963. The systematics of Crotaphytus wislizeni, the leopard lizard. Part 1. A redescription of Crotaphytus wislizeni wislizeni Baird and Girard, and a description of a new subspecies from the upper Colorado River Basin. Great Basin Nat. 23:129-148.

Tanner, W. W. and J. E. Krogh. 1974a. Ecology of the leopard lizard, Crotaphytus wislizeni at the Nevada test site, Nye County, Nevada. Herpetologica $30: 63-72$.

Tanner, W. W. and J. E. Krogh. 1974b. Variations in activity as seen in four sympatric lizard species of southern Nevada. Herpetologica 30:303-308.

Taylor, W. P. 1912. Field notes on amphibians, reptiles, and birds of northern Humbolt County, Nevada, with a discussion of some of the faunal features of the region. Univ. California Publ. Z001. 7:319-346.

Templeton, J. R. 1960. Respiration and water loss at the higher temperatures in the desert iguana, Dipsosaurus dorsalis. Physiol. Zool. 33:136-145.

Tinkle, D. W. 1959. Observations on the lizards Cnemidophorus tigris, Cnemidophorus tessellatus, and Crotaphytus wislizeni. Southwestern Nat. 4: $195-200$.

Tinkle, D. W., D. McGregor, and D. Sumner. 1962. Home range ecology of'Uta stansburiana stejnegeri. Ecology 43:223-229.

l'urner, F. B. 1971. Estimating lizard home ranges. Herpetol. Rev. 3:77.

Turner, F. B., R. I. Jennrich, and J. D. Weintraub. 1969. Home ranges and body size of lizards. Ecology 50: 1076-1081.

Turner, F. B., S. R. Lannom, Jr., P. A. Medica, and G. A. Hoddenbach. 1969. Density and composition of fenced populations of leopard lizards (Crotaphytus wislizeni) in southern Nevada. Herpetologica 25:247-257.

Warburg, M. R. 1965. The influence of ambient temperature and humidity on the body temperature and water loss from two Australian lizards, Tiligua rugosa Gray (Scincidae) and Amphibolurus barbatus Cuvier (Agamidae). Australian J. 2001. 13:331-350. 
Weiner, J. J. and H. M. Smith. 1965. Comparative osteology and classification of the Crotaphytiform lizards. Am. Midl. Nat. 73:170-187.

Wilhoft, D. C. and J. D. Anderson. 1960. Effects of acclimation on the preferred body temperature of the lizard, Sceloporus occidentalis. Science 131: 610-611.

Woodbury, A. M. 1959. Clasping behavior of the leopard lizard. Herpetologica 15:118. 